\title{
PRICE DISCRIMINATION AND COMPETITIVE EFFECTS: THE STANDARD OIL OF INDIANA CASE
}

JoHN S. McGeE†

7 HIs essay analyzes the economic aspects of certain pricing policies pursued in the Detroit metropolitan area during the middle and late 1930 's. It is something more than this, to be sure, for what the
tandard Oil Company of Indiana did there has become the subject of important legal and economic controversy. Its pricing practices were attacked by the Federal Trade Commission under the Robinson-Patman Act of 1936, and this litigation has developed into a landmark case in the interpretation of that statute. ${ }^{1}$ Therefore, while the principal purpose of this study is to evaluate one type of price discrimination, the study must also be something of a partial evaluation of the Robinson-Patman Act itself.

In the interest of brevity and simplicity, it is desirable to dispense at the outset with the problem of Standard's cost defense. The Robinson-Patman act provides that systems under which different prices are charged to competing buyers can be defended by showing that the lower prices reflect cost savings. Standard Oil of Indiana attempted to justify its lower prices to four Detroit jobbers by showing that it cost at least one and one-half cents per gallon less to serve them than to serve its tank-wagon customers. Standard's various cost defenses failed to satisfy the Trial Examiner, the Federal Trade Commission, and the Courts. Standard's cost defense is an interesting and important subject in its own right, but its analysis is not essential to the present inquiry. This essay proposes to evaluate the economic effects of a practice condemned by law as tending to lessen competition or create a monopoly. For this purpose we may assume, with the Commission, that Standard's price concessions to its jobbers were not justified by reason of cost savings.

† Research Associate, Law School of the University of Chicago. The author gratefully acknowledges his very great indebtedness to Professor George W. Stocking, who first made him aware of the importance of studying business practices and suggested that he do a study of price discrimination; to Dean Edward H. Levi of the School of Law of the University of Chicago, who provided the funds and leadership requisite for prosecuting this study; and to others of his associates at the University of Chicago who have made countless valuable suggestions, especially Aaron Director, Ward S. Bowman, Jr., John Jewkes, Robert Bork, and William Letwin.

${ }^{1}$ Standard Oil Co. v. Federal Trade Commission, 340 U.S. 231 (1951), rev'g 173 E. 2d 210 (C.A. 7th, 1949). 
Quite irrespective of what the future may bring, or what might have been done in the past but was not, this is a study of the effects of discriminatory price cutting in the framework that actually existed between about 1936 and 1940.

\section{Fewness of Sellers and Price Discrimination}

Price discrimination ${ }^{2}$ occupies a special place in legend and law. Many economists claim that price discrimination is both a mark of monopoly and an effective method by which competition may be crushed out. ${ }^{3}$

\footnotetext{
since the meaning of discrimination is somewhat different at law and in economics, it may be useful to give an economic definition. If the costs of producing for and serving all buyers are the same, a seller discriminates when he receives, for the same product, different prices from different buyers. When the seller's costs differ on sales to different buyers, the prices-net of special costs incurred on specific sales-received by the seller from different buyers, furnish a criterion of discrimination. Certain minimum costs will apply to the output sold to all buyers. When the output sold to some buyers (or classes of buyers) costs the seller more than this minimal amount, those "special" (additional) costs can be deducted from the demand schedules of those buyers for whom the "special" costs were incurred. Where costs do differ in this way, two demand schedules may be relevant for each class of buyers. The first, a "gross" demand schedule, indicates the amounts buyers will actually pay to obtain different amounts of the product. The second, a "net" demand schedule, shows the per-unit revenue the seller would receive from each class of buyers after deducting any special costs incurred for that class. Comparison of the "net" prices (those prices given by the net demand schedule at the actual amount of sales) received from different buyers shows the relative per-unit profitability of the monopolist's sales to different buyers.

Thus the existence of different (gross) prices in different markets does not necessarily mean that there is discrimination among them, for those price differences may be exactly compensated by cost differences, e.g., freight charges. On the other hand, the existence of equal gross prices (prices paid by buyers to obtain the good where they wish to use it) throughout a given market does not necessarily exclude price discrimination. Within any given market the same gross price, because of differences in the costs of serving different buyers, may yield different net prices to the seller. Similarly, there is price discrimination if price variations among markets are greater than cost differences among them, or if they are less than cost differences among them.

The foregoing standards are readily applicable, however, only to those cases in which costs are precisely and easily allocable. In practice, the difficulty of allocating the costs of certain productive factors used in common by different buyers, but used in different degrees by them, may make impossible the accurate determination of the average costs applicable to sales to different buyers. When costs are common to several products as well, the allocation problem is even more formidable.

It is important to note that, whereas theoretically the discovery of discrimination is somewhat difficult when there are common cost elements, in practice such discovery is virtually impossible.

st is almost universally contended that the pre-dissolution Standard Oil Company of New Jersey achieved and maintained its monopoly position in large part through the use of so-called predatory discrimination or "Iocal price cutting." This contention is not without defect. Without at this time exploring systematically the conditions necessary for the successful use of predatory discrimination, certain tentative observations can be made. Predatory discrimination would be expensive to predator as well as to prey. If the aggressor sells more of the product than his prey, he will suffer greater absolute damage. The process of extinguishing competition by lowering prices is very expensive when durable assets are long-lived and marginal costs are relatively low. Acquisition of competitors by
} 
Similarly, oligopoly - fewness of sellers-has come to be an important subject for economic and legal controversy. It is said that an important impediment to competition is fewness of sellers. And many more than three or four sellers may still be "few." For it appears that what economists have meant by "fewness" is not so much a matter of numbers as of attitude. We are told that sellers are few when they devote great attention to what their rivals do, and when rivals are sensitive in the same way. ${ }^{4}$

Fewness is said to result either in a gracious solicitude for the welfare of rivals, or in a paralysis of fear. When sellers are few, we are told, they recognize that unilateral, selfish activity will induce swift and stern retaliation, with the result that returns are lessened for all. Fewness thus tends to make price cutting an unattractive business technique. ${ }^{5}$

With economists' pronouncements that fewness is with us everwhere, the fear has arisen that much of American industry is not likely to be very competitive. The notion of fewness has captivated economists, government agencies, and, to some extent, courts as well.

Yet logic indicates, and industrial histories demonstrate, that, even where sellers are few, they often will compete. If they do not combine, the desire to

purchase may be more satisfactory than their pitiless and protracted strangulation. Furthermore, assuming that it would be undertaken at all, successful predatory discrimination requires effective impediments to entry into both the monopoly area upon which the predator relies for his sustenance, and into the area in which he has stricken his few rivals down. It is not clear what such impediments are.

Surprisingly enough, the voluminous briefs and records in Standard Oil Co. v. United States, 221 U.S. 1 (1911), do not confirm the contention that Standard Oil successfully preyed upon its rivals by selective price cutting, or that it systematically used the technique at all. Virtually all of the alleged instances of predatory price cutting by Standard appear to fit into one of three categories: (1) allegations that were explicitly refuted or that were not supported; (2) price cuts observed locally but which were part of much more general reductions; (3) price reductions undertaken to meet lower prices already offered by competitors. If it was used at all, predatory price discrimination was certainly not an important or systematic part of Standard's business activities. Furthermore, I have been unable to find in the Record a single instance that proves that price discrimination is a practical predatory technique. There is, of course, evidence that, in the case of railroad lubricating oils, for example, Standard exploited different demand elasticities of its customers to increase monopoly revenues.

The case of E. B. Muller \& Co., 33 F.T.C. 24 (1941), aff'd 142 F. 2d 511 (C.A. 6th, 1944), indicates clearly that even when the predator is strong and the prey is weak, predatory discrimination may not only be expensive, but unsuccessful as well. The case demonstrates that predatory discrimination is not the devastating weapon it is sometimes imagined to be.

"For the purpose of this paper, a market of many sellers is one in which each seller feels he has so little influence on market price that he neglects this influence. A market of few sellers is one in which at least some sellers feel that their influence on price is appreciable, and do not neglect it. Consult, for example, Machlup, The Economics of Sellers' Competition 350-51 (1952).

${ }^{5}$ Technically, behavior of this sort requires that each seller see his demand schedule as being iso-elastic with that facing the industry. 
advance their own interests will often be very strong indeed. This desire can best be served when rivals do not know exactly what their fellows are doing. If it is possible to sell to different buyers at different prices, and therefore to obscure to some extent the degree to which they are competing for business, the stabilizing effects of rival-consciousness may be dissipated. ${ }^{6}$ Conversely, if price adjustments must be made simultaneously all over the place, firms will naturally be more reluctant to compete. Because of their importance and possible connection, it is worthwhile to discover what happens when both rival-consciousness and differential pricing are present at the same time.

Under conditions of rival-consciousness ("fewness"), when a seller finds it advantageous to cut prices, he will usually find it preferable to do so in a selective or discriminatory fashion. Because both buyers and sellers possess imperfect knowledge, secret (discriminatory) price cutting can persist for some time. Price cutting will leave the oligopolists worse off than before. If this is so, it might appear that none would continue to cut prices. The point is that although price cutting is responsible for their worsened condition as a group, unilateral price cutting will still make it possible for any single seller to improve his position, at least if he can defer its discovery. Discrimination is an instrument of his desire to escape the detection of his rivals. Non-conspiratorial price discrimination will make an oligopolistic industry behave in many respects like a competitive one. And the ability of firms to discriminate will greatly reduce the possibility of effective collusion.

One additional complication presents itself. It may be thought that results will differ depending upon whether discrimination applies to final buyers or resellers. Since the reseller case is slightly more complicated, it may be worthwhile to elaborate it.

${ }^{-}$Anything that makes individual sellers believe that their demand schedules are of higher elasticity than that for the industry will produce price cutting. One such factor is price discrimination. Price discrimination tends to make rivals' retaliation less certain, since it veils price cuts, and, even if not secret, affects smaller portions of rivals' business at one time.

This should not necessarily be taken to mean that no price cutting will develop if sellers are not permitted to discriminate, though that is possible. What it means is that, under oligopoly conditions, price cutting will begin sooner, take place more continuously, and last longer when discriminatory pricing is possible. It is advisable to comment on the use of empirical data to test this hypothesis. Market histories seem to indicate that some price cuts by oligopolists are open and general. It is probable that many such announced price cuts are simply "official" recognition that discriminatory cutting has already reduced the actual current price below the "official" price. In short, announcement of generally lower prices may be little more than formal recognition that prices have already been cut at least to the newly announced level-something that perhaps all sellers have independently recognized some time before. Such announcement may have several purposes: (1) they bring to the attention of buyers prices that are actually lower than they may have seemed; (2) some firms may wish to inform chiseling rivals that the lower prices at which they are selling are not as secret as they thought, and that future "secret" price reductions will also be detected and met. 
For simplicity, analyze the position of an individual seller. If he has strong incentives to increase (or maintain) his sales, he will very likely discriminate. Before he does so, he must consider certain unique possibilities. If some of his reseller-customers compete, ${ }^{7}$ he recognizes that a lower price to some of them will at best mean somewhat lower sales to the others. For those who obtain the lower prices will be able to improve their position relative to those who do not. He may lose all of the business of those who pay the higher prices. Now if he is in danger of losing or has good prospects of gaining an important order, he may decide to shade his prices. If cutting price on this transaction adds more to his revenues than to his costs, he will cut. This axiom, however, obscures two important considerations. In reckoning the revenues attributable to this transaction, he must take into account the effects the price cut will have upon his other reseller-customers and upon his rivals. If (neglecting for the moment what his rivals may do) cutting his price increases net revenues from those favored more than it decreases net revenues from those who do not get the concession, the price cut is profitable. Under these circumstances the "increase in revenue from those favored" has a special meaning. If the favored reseller-customer could not go elsewhere for the same product, the seller would have more latitude. When the reseller-customer can go elsewhere, the seller may lose all his customers by refusing to make concessions. ${ }^{8}$ If the oligopolist believes that the reseller will abandon him altogether if he does not cut, in deciding whether to cut he will compare (1) the net revenues from the favored reseller which can be retained by cutting, minus the revenue lost from other reseller-customers who will lose business to the favored reseller; and (2) the amount of net revenues remaining if he does not cut his price at all. ${ }^{9}$

If the oligopolist believes that his rivals are already cutting prices, or will do so reasonably soon, or will not detect his own price cuts for a time suffciently long to make them worthwhile, he will cut. What if he does cut? First, it is likely that other sellers will also cut, selectively if not generally. This is likely because either: (1) other sellers face the same difficulties and may evaluate them similarly, or (2) ultimately the fact that prices are being cut

\footnotetext{
"For this competitive relationship to obtain, it is not necessary that the resellers be all "wholesalers" or all "retailers." For wholesalers, by passing along the price concessions they get, may cut into the amounts sold to retailers they do not serve; and retailers, receiving benefits of price concessions made directly to them or indirectly benefiting from cuts made to their wholesalers, reduce the sales of other wholesalers.

8 The oligopolist knows that rivals may be evaluating their own best interest in the same way that he does. To qualify for a price concession a customer may only have to point out that he has gotten better offers. For the oligopolist knows that there is a good probability that better offers have been or will be made. If a price cut is attractive to him, it may also be attractive to his rivals.

- The aggressive reseller may still contribute something to the oligopolist's net revenues if the price is cut to him, and will contribute nothing if all of his business is lost.
} 
will be discovered, and those who have not been cutting, or have not cut enough to maintain their position, will cut. This kind of selective price cutting drags down the whole price level, but does so in bits and pieces, not with an explosive collapse.

Discrimination may upset price stability gained only after expensive and protracted price wars, cajolery, and cooperation. In the absence of complete collusion, it is virtually impossible for each firm to sell at several (or many) discriminatory prices in a way which will achieve its individual objectives yet still be compatible with group interests. The greater the number of variables (in this case, prices) independently considered by oligopolists, the more intimate and continuous must conspiracy be if it is to succeed. This is especially true when the interdependence of resellers' markets is significant. Even in industries skillfully employing collusion or coercion to assure identity of purpose, solidarity has often been broken by secret, unilateral discrimination.

This is true on two market levels. The remarks so far have been directed to rivalry among sellers at the primary level. It is no less true, however, that the formation and maintenance of a cartel among the resellers themselves will be rendered immensely difficult when sellers are discriminating independently. For one of the fundamental impediments to successful cartelization is the difference that may exist among the costs of those who would benefit from cooperation, and especially, the changes that occur in those costs over short periods of time. The successful management of potential rivals, who at best may fall upon one another at any time, can easily be frustrated by any substantial differences in efficiencies or costs of supplies that may exist among the group, and quick or frequent changes in those differences. And the existence of unilateral price discrimination among the primary sellers guarantees that, so long as it persists, costs will tend to vary among the resellers. Indeed, given the lack of confidence cartelists sometimes have in their fellows, it would not be too surprising if even a fear or suspicion that advantages have been gotten by some and not by others caused intense competition to crop out from time to time.

If oligopolists are to discriminate among interdependent markets without involving themselves in price competition, a highly detailed and continuous collusion appears necessary. The additional relationships among buyers' markets, as well as rivalry among oligopolists, make a spontaneous, noncollusive monopoly equilibrium practically impossible.

Furthermore, at least some of the price advantages that resellers bargain away from sellers will very likely be passed along to final buyers. Because the resellers are rivals, lower prices at the resale level tend to attract final buyers to those resellers who charge the lowest prices. Price rivalry then increases at the resale level (as well as at the primary seller's level), and final buyers will benefit. 
But what about those resellers who do not, initially at least, get the more favorable prices? When one seller begins to cut prices selectively, it will have two effects. (1) The quantity purchased by those of his customers who do not receive the lower prices, yet who compete with the favored buyer, will decline. (2) The resellers who buy from other sellers will, if they compete with the resellers served by the price-cutter, also suffer a decline in sales. Orders placed with the other primary sellers will decline. Resellers who suffer because of the higher prices they pay will try to improve their positions. The disfavored reseller-customers of the price-cutter may be able to get a better bargain from from their present supplier, even though they did not get it before, ${ }^{10}$ for some suppliers will have lost business, and presumably will be in a mood to cut prices. Even if they cannot, they can go elsewhere. For other suppliers now suffer a lessened demand for their products as a result of the price cutting of their rival and the outbreak of price rivalry among the resellers.

Since there are alternative suppliers, disfavored resellers can very likely get better prices elsewhere. Resellers who are temporarily disfavored then switch their trade to others who cut their prices to attract them. Prices to everyone would then be forced down, perhaps to marginal cost. This follows because the competitive price discrimination of one (or more) sellers is redistributing business in their favor when already there is not enough business at current prices to utilize fully the capacity of the industry.

On the other hand, if the same resellers enjoy the lowest prices throughout this process of price cutting, and if they take full advantage of their preferred position, some disfavored resellers may be pushed out of the field. Competition could conceivably be lessened in the process. This becomes possible if there are no alternative suppliers who are willing to cut prices to resellers who are temporarily forced to pay the higher prices. ${ }^{11}$ Price discrimination thus tends to increase price rivalry where sellers are rival-conscious.

Price discrimination is generally denounced as an instrument of monopoly. Far from being exclusively the device of a monopolist who seeks to exploit his markets fully, price discrimination is also a useful and common instrument of rivalry. This analysis suggests that price discrimination can make competition more effective than it would be if discrimination were prohibited.

It may be useful at this point to test this logic by examining an actual fact situation, that of the Detroit gasoline market from about 1936 to 1940.

\footnotetext{
${ }^{10}$ Compare Fein, Note on Price Discrimination and the A \& P Case, 65 Quar. J. of Econ. 271-80 (1951), and Adelman, Comment on Fein's Note, ibid., at 280-83.

11 The theoretical literature, almost without exception, has treated price discrimination as though it arises when there is only one seller. When there are several independent sellers, the consequences will of course be different. For examples of the usual presentation, see Robinson, The Economics of Imperfect Competition, c. 15 (1946).
} 


\section{Standard Oil and the Market}

The so-called "Detroit Gasoline Case,"12 which deals with the practices of the Standard Oil Company (Indiana) in the Midwest gasoline market shows what happens when firms sell at different prices in an atmosphere of rivalconsciousness.

The Standard Oil Company (Indiana) is a large, integrated producer of a wide range of petroleum products. ${ }^{13}$ It originally sold in some ten or eleven states, and at the time of the events analyzed here, did business in fifteen states. By dissolving its parent, the Standard Oil dissolution of 1911 made Standard of Indiana an independent concern. Whatever caused it, it is a remarkable historic fact that the relative position of Standard of Indiana steadily declined in the territory it served. Estimates by long-time employees of Standard of Indiana indicate that for the first twenty years the Company did from seventy-five to one hundred per cent of the business in its marketing territory, the percentage varying with locality. ${ }^{14}$ By 1928 , Standard's share of the gasoline market had shrunk to about thirty-four per cent. By 1940, the figure had fallen to about twenty per cent, and remained below twenty per cent at least until 1950. This relative decline was gradual. ${ }^{15}$

There are many explanations for the phenomenon. One of them runs in terms of the high prices charged by the dominant firm in the face of gradual entry by newcomers. This explanation has a basis in economic theory, and is recognized by industry leaders as well. ${ }^{16}$

${ }^{12}$ Standard Oil Co. v. Federal Trade Commission, 340 U.S. 231 (1951). Citations to Record hereafter are to the transcript of the record published as part of the Briefs and Records for the appeal to the Supreme Court. The pagination is of the printed record.

${ }^{13}$ By far the largest seller of Standard's three grades of gasoline was its Red Crown or "regular" gasoline. About 90 per cent of its gasoline sales were accounted for by Red Crown. For that reason, as well as because of the gains from simplification and the relative scarcity of information with respect to the other grades, this study will be concerned only with Red Crown gasoline.

14 Wilson, Oil Competition in the Midwest 17 (The National Petroleum Association, 1950). [Address delivered at the 47th Semi-Annual Meeting of the National Petroleum Association on April 13, 1950, in Cleveland, Ohio.]

${ }^{15}$ Statement of John W. Boatwright, on behalf of the Standard Oil Company, In the Proceedings Before the House Interim Committee of the Legislature of the State of Michigan, Held Pursuant to Resolution No. 42, October 1, 1951. (Mimeo. 13-14.)

${ }^{16}$ As Warren C. Platt, editor of the National Petroleum News summed it up in 1939: "But the Standard companies have been slipping each year from their old dominating position. . . . In all these 27 years the Standards, for the most part, have continued to be the highest price sellers, although that today is subject to qualifications in special circumstances. . . . Their's have been the prices at which everyone has been shooting, they have been accepted, even down to date, as the 'market leaders.' But under the umbrella the Standards have held in the form of the top price have come thousands of competitors, big and little, with all sorts of operating and selling costs and with an equally varied assortment of abilities. As it got crowded under the umbrella, the Standards have lowered it, to keep it from casting so much shade, but there always has seemed to be room for one 
In addition to the peculiar long-term forces that reduced its share of the market, Standard, like its fellows in the industry, was subjected to cyclical fluctuations and certain irregular shocks and disturbances. Whereas this analysis is chiefly concerned with what happened in the Detroit gasoline market, it may also be useful to summarize the state of the American petroleum industry during the early 1930 's. ${ }^{17}$

In general, although the industry has grown rather steadily, its history has been one of alternating periods of dearth and surplus. In the words of one industry expert: "The problem of oil, it might be tersely said, is that there is always too much or too little."18 And, from the standpoint of the industry (and certain conservationists as well) the 1930's were surely years of great petroleum surplus. Even the prosperous 1920's were troubled years for the industry, chiefly because of an unprecedented flood of newly discovered oil. Troubled years though they were, they were not disastrous, for the rising trend of gasoline consumption continued to alleviate the industry's distress. ${ }^{10}$

The industry's greatest trial came in the 1930's, when rising petroleum output from the new "flush" East Texas field coincided with a shrinkage in national income and gasoline demand. While the effects of the great Seminole field (1926), and the lesser Oklahoma and West Texas discoveries lingered

more, no matter how low the umbrella got." Nat'I Petroleum News, p. 26 (Aug. 23, 1939).

Although policy makers in Standard of Indiana on occasion pointed almost pridefully to the decline in that company's market share as a symptom of a socially desirable competition, it was not always considered a blessing even outside the company. Indeed, one commentator on the industry saw in the decline of the Standard Companies a woeful sign of industrial chaos. In a 1939 editorial Platt bemoaned the lack of stable leadership in the oil industry, and blamed the relative decline of the Standard Companies. According to Platt, the 1911 dissolution and the new and troublesome independence of filling station operators were major causes of the fearful state of the industry. Nat'l Petroleum News, p. 23 (Aug. 23, 1939).

${ }^{17} \mathrm{~A}$ number of works adequately treat this or earlier periods of the industry's fascinating history. See, for example, the classic work, Stocking, The Oil Industry and the Competitive System, esp. c. 2-10 (1925); and Watkins, Oil: Stabilization or Conservation? esp. c. 5-14 (1937).

${ }^{18}$ Watkins, op. cit. supra note 17 , at 40.

Io "In 1920 there were drilled in the United States 33,911 wells, more than 4,000 in excess of the number drilled in any other year, before or since. Moreover, of these, 24,273 were brought in as oil producers, likewise an unapproached record. In the next three years domestic crude production mounted at an accelerating rate and in 1923 was double what it had been in 1919. This unexampled expansion of crude supply more than kept pace with the growth of the demand for motor fuel and other refined products. With Mexia (Texas), Smackover (Arkansas), and Signal Hill, Santa Fe Springs, and Huntington Beach (California) all 'in the flush,' an oil flood replaced oil scarcity and conservation talk dwindled. But again chance demonstrated its mastery of the situation and no spectacular new fields were brought in after 1923 until 1926, when prolific Seminole (Oklahoma) abetted by the Panhandle (and West Texas) began putting a fifth wheel on the market wagon. That it was not immediately upset was due to the steady expansion of the demand for gasoline." Ibid., at $41-42$. 
on, the fabulous East Texas field (1930) came upon the sagging industry like a thunderbolt. ${ }^{20}$ Indeed, chaos in the East Texas oil field was so comprehensive that for a short time martial law was established in it. ${ }^{21}$ Prices fell precipitously. ${ }^{22}$

The law of capture, the fugacious character of petroleum, and dispersion of ownership of petroleum would tend, even in normal times, to produce feverishly competitive exploitation of petroleum resources. ${ }^{23}$ Furthermore, several other factors combined in the thirties to accentuate downward pressures on oil and gasoline prices. Gasoline yields increased as a consequence of improved technology; ${ }^{24}$ gasoline consumption decreased or declined in its rate of increase. When to these forces was added a tremendous, discontinuous increase in the output of petroleum, it is no wonder that the price structure collapsed. Neither the formal cooperation and stabilization of the National Industrial Recovery Act, Interstate Oil Compacts, state proration schemes, nor private cooperative arrangements to clear from the market temporary "distress" offerings ${ }^{25}$ of gasoline were enough to prevent widespread price cutting in the petroleum industry.

During the 1930's it is clear that discriminatory price cuts were an important competitive technique. They were employed by large firms and small, and at every level of the industry-from the well to the retail pump. Open price announcements lagged far behind the more or less secret and selective price cuts that really made the market price. ${ }^{26}$

${ }^{20}$ Rostow, A National Policy for the Oil Industry 19-21 (1948).

${ }^{2}$ Swensrud, Distribution Problems of the Oil Industry, 9 Harv. Bus. Rev. 389, 392 (1931).

2 According to Watkins, "Mid-Continent crude ( $36^{\circ}$ gravity) fell from $\$ 1.229$ per barrel at the beginning of 1930 to $\$ .745$ per barrel at the end of 1932, and at the lowest level, in July 1931, the average price was only $\$ .238$ per barrel. In the same period the average service station price of gasoline in 50 representative cities, exclusive of taxes, fell from 17.23 cents per gallon to 12.96 cents and touched a low of 12.21 cents in September 1931 . Accompanying this drastic decline of prices there was an unprecedented abandonment of wells. From a total of 7,482 abandoned in 1929 , the number rose to 15,672 in 1930 , and to 21,603 in 1931, the 'worst' year of depression for the industry. Many of these were only 'shut in,' however, thus adding to the uncertainty of the volume of potential production which a rise in price might release." Watkins, op. cit. supra note 17, at 49-50.

${ }^{2}$ Stocking, op. cit. supra note 17 , at $115-210$; Watkins, op. cit. supra note 17 , at $8-40$; Swensrud, op. cit. supra note 21, at 393; Lewis, The Marketing of Petroleum Products, 14 Harv. Bus. Rev. 312 (1936) ; Rostow, op. cit. supra note 20, at 17-18.

"Swensrud, op. cit. supra note 21 , at 391 .

${ }^{25}$ United States v. Socony-Vacuum Oil Co., 105 F. 2d 809 (C.A. 7th, 1939), rev'd 310 U.S. 150 (1940).

* There are many examples. The situation in the crude market is revealed in the following ones: In August, 1938, major companies lowered their offer-price for East Texas crude 10 cents per barrel. It was generally known in the industry, however, that this openly announced ("official") price cut was simply recognition that undercover price cutting had already reduced the effective price level. Nat'l Petroleum News, pp. 11, 20 (Sept. 
If the oil industry in general was competitive, restive, and distressed, the Midwest, especially Detroit, was one of its most troubled parts. ${ }^{27}$ This may be accounted for by several factors. First, aggregate gasoline consumption is influenced importantly by personal income. And, the depression hit Detroit and other industrial centers even harder than the nation as a whole. ${ }^{28}$ Second, Detroit was a large gasoline market, and a considerable number of sellers offered gasoline in it. ${ }^{29}$ Third, the discovery and rapid exploitation of

7, 1938). Consult also, ibid., p. 20 (Sept. 21, 1938). In early October, worsened market conditions were reflected in very important open price changes. Standard Oil of Indiana and the Humble Oil and Refining Company announced 20 cent-per-barrel reductions in their posted crude oil prices in Oklahoma, Kansas and Texas, preceded apparently by selective price cutting. Ibid., pp. 5-7 (Oct. 12, 1938). On August 10, 1939, Sinclair cut its Mid-Continent crude price. According to the National Petroleum News, the "[e]vents set in motion when the Sinclair interests announced their price cut Aug. 10 have created the most serious situation in the crude producing fields in the southwest since 1931." Ibid., p. 9 (Aug. 16, 1939). Such open price cuts apparently had been preceded by widespread undercover price cutting, for "Wm. S. Farish, president of Standard Oil Co. of New Jersey, told Sadler that Humble had advised that more than 500,000 barrels of crude oil were moving to market daily at under market prices and in competition with Humble's purchases at its posted price." Ibid., p. 10 (Aug. 16, 1939).

The gasoline market reports reveal much the same process. A June, 1936 report is representative: "the price shading that was indulged in by several sellers throughout the week, most of which was undercover ... left no lasting impression on gasoline prices generally." Ibid., p. 49 (June 24, 1936). Consult also, ibid., pp. 58-59 (July 8, 1936); p. 44 (July 29, 1936). Even when observers were sure that the market price was falling, it was difficult to tell how much the market had actually fallen because of the undercover and discriminatory character of the price reductions that were undermining the market. As the National Petroleum News reported, "With this situation prevailing, that is, sellers ostensibly holding gasoline for published prices, but 'meeting competition' it became increasingly difficult to record the low spots of the market." Thid., p. 44 (July 29, 1936). Consult also, ibid., p. 56 (Aug. 19, 1936); p. 45 (Sept. 2, 1936); p. 52 (Sept. 9, 1936).

Undercover price cutting occurred at all levels: "Dealers talk freely in Detroit. For example, one dealer said he could get all the gasoline he wanted from 'up state' at 6 cents a gallon in 1000 gallon dumps, provided he took it 'after 2 A.M.' This price would permit him to undersell his competitors and still make a profit. Another dealer reported that it is common practice for dealers who give secret rebates to paint the insides of their 'favored customers' gas tank caps so that they can be recognized without difficulty when buying gasoline at the stations." Ibid., p. 27 (Aug. 18, 1937).

${ }_{27}$ The Midwest "is almost always the first market to reflect easier prices and almost always the market in which comparable grades of gasoline are available at under quotations in other districts." Ibid., p. 58 (July 8, 1936).

${ }^{2}$ For example, whereas the national gasoline consumption during the first four months of 1938 was 2.8 per cent higher than for the same period in 1937, Michigan gasoline consumption actually fell some 3.52 per cent. This poor record was common to the experience of other industrial states, for "[o]f the seven leading industrial states, four indicated decreases, these being Massachusetts, Michigan, New York, and Ohio." Ibid., p. 13 (July 6, 1938). Although for the nation as a whole gasoline consumption in 1938 broke all records, rising .8 per cent above 1937 , Michigan consumption actually fell 5.10 per cent. Tbid., p. 18 ( $M a r c h ~ 8,1939$ ). By August, 1938, Michigan gasoline consumption had fallen 9.17 per cent, the level of the same period a year before. Ibid., p. 17 (Sept. 7, 1938).

${ }^{20}$ See Resp. Exh. No. 38A-38E, Record, 4864-67; and Resp. Exh. No. 63A-63C, Record, $4885-86$. 
local crude supplies and the construction of local refineries created downward pressures upon prices. ${ }^{30}$ Fourth, Detroit is well-located with respect to major means for transporting petroleum products. ${ }^{31}$

\section{Outline of Marketing Arrangements}

In the Detroit area, the Standard Oil Company of Indiana maintained large volume gasoline storage facilities at its River Rouge marine terminal, into

${ }^{30}$ As the following table clearly shows, gasoline refinery capacity, both straight run and cracking, increased greatly and continuously in Michigan from 1935 through 1940.

\begin{tabular}{|c|c|c|c|}
\hline Year & $\begin{array}{l}\text { Number of } \\
\text { Refineries }\end{array}$ & $\begin{array}{l}\text { Capacity in } \\
\text { Straight } \\
\text { Distillation }\end{array}$ & $\begin{array}{l}\text { Cracking } \\
\text { Capacity }\end{array}$ \\
\hline $\begin{array}{l}1935 \\
1936 \\
1937 \\
1938^{*} \\
1939 \\
1940\end{array}$ & $\begin{array}{l}17 \\
19 \\
23 \\
26 \\
24 \\
29\end{array}$ & $\begin{array}{l}38,550 \\
47,100 \\
62,500 \\
71,350 \\
78,100 \\
87,050\end{array}$ & $\begin{array}{r}7,400 \\
15,300 \\
17,200 \\
11,050 \\
12,604 \\
17,020\end{array}$ \\
\hline
\end{tabular}

Source: U.S. Bureau of Mine Data, Adapted from Resp. Exh. No. 25B, Record, 4828 .

* Figures before 1938 represent cracking stock charged; subsequent years represent cracked gasoline actually produced.

Crude oil supplies in the Midwest also contributed to the pressure on prices: "interest in Michigan as a producing state is growing again. The state's production is now running over 30,000 barrels a day, with 75 wells drilling, many in areas which are looked upon as favorable for oil. ... Some of the smaller refineries which have been shut down for lack of crude are preparing to start up, now that the state's production is increasing. Production restraint so far in the history of the Michigan field has been for the most part voluntary in nature." Nat'1 Petroleum News, p. 21 (March 17, 1937). A bill for controlling oil output was introduced into the Michigan legislature at this time. Ibid. By April, Michigan production was raised by the new Buckeye Field activity, and reached between 40,000 and 45,000 barrels daily output. Ibid., p. 167 (April 21, 1937).

${ }^{31}$ In recalling his experience in the oil business, $\mathrm{Mr}$. P. A. Raupagh, Manager of the Detroit Division of the Standard Oil Company of Indiana, summed up the Detroit situation in these words: "It is the most highly competitive point in which I have ever operated, and it is generally considered one of the, if not the most, highly competitive, a very highly competitive spot as far as the oil industry is concerned. . . . Some of the reasons for that condition are: first, that we have here a very large potential market for gasoline; we have a large city; we have a large industrial activity in this city; it is so located that its distributors are easily accessible, as far as the transportation is concerned, on account of being located on the Lakes. You can get good water transportation. It is, of course, very easily accessible by rail. Furthermore, we have Michigan refiners who are producing a fairly good grade of gasoline and are continually improving their gasoline, and who must find a market here in Detroit. Years back, it used to be considered that Detroit was a sort of dumping ground for gasoline, and that whenever refineries from farther away, the Mid-Continent field, or, I mean, Oklahoma, and so on, had a surplus of gasoline, and so on, and even if they were not marketing in this area, they felt this was a good place to dump it, because transportation facilities were good, and so on." Record, 1900-1901.

There were about thirty Michigan refineries which produced some 30 per cent of the total Michigan gasoline requirement. Record, 1901. There were also about ten or eleven important gasoline marine terminals in the Detroit area. Ibid. 
which it moved gasoline from its Whiting, Indiana refinery. ${ }^{32}$ In addition to the marine terminal, Standard operated some six bulk plants, which were served by hired truck transports that moved gasoline from the River Rouge terminal. $^{33}$ Each bulk plant served Standard's customers in a distinct geographic territory. Aside from the relatively few large industrial purchasers served directly by the Company, Standard sold gasoline to two chief classes of customers, retail dealers and jobbers.

As of December 31, 1940, Standard of Indiana served directly some 357 retail filling stations in Detroit. ${ }^{34}$ It owned about 200 of these outright, although it did not directly operate them. ${ }^{35}$ It leased and subleased an additional eight or ten stations. ${ }^{36}$ Standard Oil dealer arrangements were of two varieties. Some dealers leased filling stations that Standard owned or controlled. Terms varied, but typically provided that lessees make flat monthly payments plus a so-called "gallonage rental." for one year, though some were as long as three years. ${ }^{38}$ The terms of the lease varied among Standard stations..$^{39}$ Filling station operators who owned their own stations or leased them from someone other than Standard signed the Company's "Contract 461." 40

\footnotetext{
${ }^{32}$ The capacity of the storage facilities was some $1 \frac{1}{2}$ million barrels of 42 gallons each. Record, 100. Standard had no Michigan refinery, and was somewhat disadvantaged by the necessity of accumulating sufficient stocks over the Lakes' navigation season to last the rest of the year. This arrangement evidently became too burdensome, for by 1953, Standard had completed and was using a pipeline to transport gasoline from its Whiting refinery to the River Rouge terminal.

${ }^{33}$ About 10 to 15 per cent of total gasoline movements through the River Rouge terminal took the form of movements from the terminal directly to dealers, without an intermediate rest in the Standard bulk plants. Record, 109.

34 Comm'n Exh. No. 128A, Record, 4785-86. In views of claims that Standard's practices were predatory in character, it is interesting that three years earlier it served 358 stations.

${ }^{35}$ Before September 1936 , it had done so but began withdrawing from filling station operation about that time. Various reasons are given for this voluntary disintegration. Among the more important are: (1) endeavor to escape anti-chain store taxation of multiple outlets; (2) effort to avoid certain costs involved in the Social Security program; (3) a belief that certain business functions could be improved given the alleged incentives stemming from independent operation or ownership.

${ }^{38}$ Record, 102.

${ }^{37}$ Record, 103-4. See Comm'n Exh. No. 1A-1D, Record, 4702-12.

${ }^{38}$ Record, 105.

${ }^{\circ} \mathrm{Mr}$. Harold R. Hanley, counsel for Standard, cited the following as factors influencing filling station lease terms: (1) investment, (2) location, (3) amount of gallonage, etc., and (4) the general competitive situation. Record, 137.

"For a copy of a "Dealers Agreement" see Comm'n Exh. No. 2, Record, 4713-15. The language of the Agreement's "tying clause," which has since been changed, seems to require only that Standard gasolines be bought from Standard of Indiana. Apparently Standard hoped that its dealers would interpret it as a total requirement or exclusive dealing contract, though it was never legally tested. That it was not in practice an exclusive arrangement is demonstrated by the fact that some Standard dealers sold Ford Benzol gaselines. Most of them also apparently sold the motor oils of Standard's rivals.
} 
In the gasoline industry, as well as in other trades, manufacturers commonly sell at different prices to buyers who perform different distributive functions. For example, it is common for producers to sell to wholesalerswho typically buy in large quantities, assume the risk and expense of storage, and deliver to advanced elements in the hierarchy of distribution-at more favorable prices than to retailers to whom they sell directly. ${ }^{41}$

What complicates matters is that two or more different functions are frequently combined within a single firm or central management; and firms performing widely differing functions may all be called "jobbers" or wholesalers. ${ }^{42}$ In general, a firm will "farm out" those distributive or other functions that it can get done cheaper in the open market than within its own organization. ${ }^{43}$ On the other hand, some firms, like Standard, found it advantageous to use both methods. ${ }^{44}$ This might be because the firm hopes thereby to achieve flexibility, to provide empirical cost control, to discriminate in price, because costs are equal for either alternative, or for other reasons. Thus

"As James E. Dyer, officer and long-time employee of Sinclair put it, "The usual and ordinary method that a refiner having no direct marketing facilities of his own uses-is to either sell all or a part of his refinery output to other concerns in the industry who do have such facilities, or to sell these products to jobbing companies who buy the material from the refiner and resell it to resellers and to consumers and to their own service stations." Record, 943. That, however, should not be taken to mean that only non-integrated firms used jobber distribution. According to Dyer, "It is a generally accepted method, and is not confined to large or small refiners, nor to integrated, semi-integrated, or any other division of the industry." Record, 942.

"The so-called "yard-haulers" are an example of a type of distributor intermediate between the strictly retail dealer and the jobber. According to John C. Marshall, Manager of Standard's gasoline and refined oil department, yard-haulers "take over the transportation of the product from the bulk plant to their own service stations. In other words, they are permitted to drive into what is ordinarily the bulk plant, as distinguished from the terminal or refinery, with their own trucks and to do their own transportation and they get a yard price on the basis of being yard-haulers, which is just another ramification of this competitive activity in the oil industry." Record, 1122. In addition to yardhaulers, there were other intermediate or "mixed" types. Some jobbers evidently paid prices sufficiently low to enable them to resell to other jobbers. Record, 2070.

"In the words of Mr. Dyer, "[T] he thing that keeps it more or less in equilibrium is if the refiner is selling through to the consumer, employing jobbers, and he finds out he can perform that function at a less cost himself, he will do it himself." Record, 952.

"Spokesmen for the Standard Company have found both disadvantages and advantages in the so-called "dual distribution" system. As disadvantages they cite the following: (1) jobbers may come to be dominant or of such major importance in some communities that they actually determine pricing policy for the supplying company; (2) the supplier often inherits blame for the actions of his jobbers though he may have little knowledge or control of what they do; (3) the quality of service and merchandise sold by stations supplied by jobbers is generally more difficult to control. Alleged advantages cited are the following: (1) jobbers provide a method for expanding into an area without great investment in bulk plant facilities; (2) jobbers may merchandise more aggressively than the Company, because of flexibility and some unnamed incentives; (3) jobbers may have more intimate knowledge of markets, and act more speedily to meet competition; (4) because of being "local businessmen," and because of more intimate knowledge of local markets, jobbers may be able to obtain locations for less than would the supplying company. 
Standard sold to filling stations directly, and in addition sold to four jobbers in the Detroit area who took delivery in large quantities, stored, and further distributed the product. ${ }^{45}$ As is apparently altogether usual, all of these jobbers at one time or another sold important quantities of gasoline through their own retail stations, and one of them, Ned's Auto Supply Company, was exclusively a retailer. ${ }^{46}$

Standard delivered gasoline in larger quantities and at lower prices to jobbers than to ordinary retail dealers. ${ }^{47}$ Moreover, whereas the jobbers themselves performed and paid for certain services provided for outlets they sup-

${ }^{15}$ In this connection, however, it is interesting that Standard of Indiana sold relatively less of its total volume through jobbers than did the average major company.

${ }^{16}$ For the detailed analysis of the percentage of their total business done through their own retail outlets, see Table 1.

The dual role of the jobber is to be explained, at least partially, by his historical development. As one industry expert put it, "Usually the business of becoming a jobber is a matter of evolution. Many a jobber started off with a curb pump, or with one service station. Then he has gone into the business, usually, of establishing storage for taking carloads of supplies. When he does that, he invades the function of the jobber but he doesn't give up his retailing; he continues to be a retailer.... that is the basis on which the business is built. That is the basis on which most jobbers operate." Record, 967. According to undisputed testimony by both the Commission's and respondent's witnesses, the typical jobber in the oil industry sold both at wholesale and retail, though he usually was not exclusively a retailer. For example, see Record, 338, 943, 946. There were, however, some outstanding examples of jobbers who sold only at retail. For example, the Texas Company served at jobber prices the exclusively retail stations of Firestone Tire \& Rubber Co., B. F. Goodrich, and Bulldog Oil Co.; Gulf served Firestone and Goodrich. Record, 2073. Many jobbers were primarily retailers.

${ }^{17}$ From the River Rouge terminal it delivered gasoline to the jobbers in large transport trucks-called tank cars-whose capacity ranged from 6,500 to 12,000 gallons. Record, 122 . Only rarely did Standard supply its jobbers directly from the Whiting refinery. Large industrial consumers-"commercial accounts"-got gasoline deliveries from the River Rouge terminal. Record, 124. The price paid for gasoline delivered in that way and in those quantities is customarily known as the tank car price. The term "tank car" evidently has its origins in the older practice of delivering full railroad tank cars of gasoline and other petroleum products to the bulk plants of jobbers and other "trackside operators." The other, and much more numerous, class of filling station operators usually received gasoline from trucks whose capacity ranged from 600 to 1500 gallons, the latter figure being typical in 1937. Record, 3002. By 1942, the maximum size was 3,000 gallons. Record, 3307. The growth in size of truck capacity apparently explains, in part at least, the trend to increased shipments to retail outlets directly from the River Rouge terminal. Record, 33067. By 1942, the percentage of total tank-wagon reseller gallonage made by such shipments had climbed to some 35 to 40 per cent. Record, 3306. This change presumably effected different cost functions. The price they paid was called the tank-wagon price. The average size of gasoline delivery to the retailers was smaller than that made to jobbers. Between 1936 and 1940 , the jobbers paid Standard prices that were $1 \frac{1}{2}$ cents per gallon below the tank-wagon prices paid by the ordinary retail dealer. Whereas Standard provided favorable prices to its jobbers, the jobbers were important to the Standard Oil Company. For in 1940, the four Standard Oil jobbers sold approximately 18 per cent of all the gasoline Standard sold in the Detroit area. Resp. Exh. No. 58, Record, 4879. This was a sufficiently large part of the Company's business that Standard was concerned over the possibility of losing it. 
plied, Standard supplied analogous expensive equipment and services to its ordinary retailer customers. ${ }^{48}$

It is very important that, although the Standard jobbers did assume part of the wholesaling functions and costs, not one of them was able to obtain the tank-car price without bargaining for it. Indeed, as we will show, the very process of giving jobber status to gasoline marketers was an important competitive technique in the gasoline market from 1936-1940.

\section{The Growth of Non-Major Supplies}

The deepening depression engendered at least two forces making for a growing number of firms marketing gasoline at below prevailing prices, and they eventuated in protracted price wars. The first of these was the growing margin between the "spot car market" for gasoline and the price paid by consumers; ${ }^{49}$ the second was the increasing price consciousness of consumers. Abundant and cheap crude oil and gasoline made the existing price structure sufficiently high to encourage the growth of non-major competition..$^{50}$ And

${ }^{18}$ The four Standard Oil jobbers paid for and maintained their own bulk storage facilities, vehicles, pumps and equipment, sales force, and advertised on their own account. Since this advertising featured Standard's products, Standard benefited from it. They also supplied their dealers with pumps and equipment and maintained them, and defrayed the expenses of credit investigation and collection. Record, 1895-97.

"According to Mr. Boatwright, the spot car market is "[t]he accepted tank car market by given communities." Record, 1416.

${ }^{50}$ In the words of Mr. Boatwright: "I am talking about the margin between the price to the consumer as maintained by the reseller on one side, and the recognized spot market on the other. ... As that margin widens the distribution of gasoline attracts capital, which, in turn, attracts additional distributing facilities. These additional distributive facilities, to acquire volume, will offer an incentive to the consumers. The change of your pattern of distribution in a given market may take a year in its completion, but it is a change that will take place in that market whenever your gross margin between these two price levels reaches a point sufficient to attract added capital into the distribution of petroleum products. I should state that that margin required to acquire capital will vary among different metropolitan areas; will likewise vary according to different economic conditions in different areas; and will vary according to the degree of satiation that there is in that market of the particular class of cut price distributors. But in each market there is some level at a given time in which this margin becomes an effective means of inviting competition." Record, 1416-17.

Questioning of Mr. Raupagh developed his belief that abundant and cheap crude supplies in the face of stable gasoline prices virtually guaranteed the entry of price-cutting marketers. According to Mr. Raupagh: "Crude oil was down in price in 1938 and I can't recall just how much. ... It means that there is, first, a surplus of crude oil and it means, second, that refiners are able to secure all the crude oil that they want at a low price and . . . consequently, they sell it to their trade at a lower price." Record, 1908.

The presence on the market of surplus gasoline had an even more immediate effect on retail prices. As Raupagh saw it, "Another factor that was very effective to demoralize the retail market in 1938, there was a surplus of Michigan gasoline. The Michigan refiners were offering to dealers Michigan gasoline at $3 \xi$ below the prevailing tank wagon dealer price." Record, 1908.

However, the so-called major or nationally known brands of comparable specifications 
shrinking income and employment made gasoline buyers more price conscious. ${ }^{51}$

Total gasoline consumption appears to have been influenced more by factors determining the number of automobiles in $u \mathrm{~s}^{52}$ and the intensity of their use ${ }^{53}$ than by the price of gasoline. Oil industry economists believe that the aggregate demand for all gasolines-whatever the precision of such a concept may be-is price inelastic. Thus, whereas a price cut by only one marketer may rapidly increase sales at the expense of his rivals, when all

generally sold for about the same price, and brought higher prices than local or lesser known brands, some of which were technically at least as good as the major gasolines. The major brands of comparable grades were very close substitutes one for the other, and price cuts by one major seller would rapidly eat into the custom of the others unless they were met. That is, the elasticity of demand faced by a single seller was very high, assuming that rivals' prices did not change with his. In addition, a price increase by one major that was not followed by the others would be abortive. Finally, major gasoline sellers watched the actions of their rivals very carefully, and were themselves watched in turn. Probably much the same remarks apply to the non-major gasolines taken together.

Major and non-major gasolines coexisted in the same markets. They were strongly interdependent. All of the gasolines involved were motor fuels adaptable in varying degrees to the same purpose, and at least some consumers knew of the closeness of their technical substitutability. As a consequence, non-major gasolines became better substitutes for major products the cheaper they became relative to major gasolines.

In summing up the impact of the non-major brands upon the business of Standard of Indiana, Mr. Boatwright relied upon empirical studies designed to show that influence. As Mr. Boatwright put it, "the unusual growth that was taking place during the year 1938 in this market by this class of distributors led to our department being assigned the task of studying prices. Three times between the month of March and the month of July, when the price differential is the widest, the growth of the volume as indicated by the tax reports is the more rapid. As the price differential is reduced, the growth is reduced, or it may even be reversed." Record, 1398. See also Record, 1399-1415, and Resp. Exh. Nos. 27, 28, Record, 4829-30. That this relationship held good in other markets is shown by Resp. Exh. No. 29A, 29C, Record, 4831-33. Of course, these relationships applied with varying force depending upon surrounding circumstances. For example, the effects of price cuts tend to be more rapidly transmitted when advertised or conspicuously posted than when they are not. Distance between outlets is also important, as is their direct connection by major automobile traffic routes. Record, 1413-16. The differentiation of major gasolines appears to have been very slight at the same prices. Stations lying along the same traffic routes and selling different major gasolines tended to be pulled along together very rapidly by the price cutting of their fellows. The markets of filling stations seem to have been interlinked and the tendency of stations to be located along high density traffic routes heightened the willingness and ease of motorists to compare prices. Record, 1414-16. Consult Chamberlin, The Theory of Monopolistic Competition 103-4 (1950).

${ }^{o r}$ It was Paul H. Harrison's view that "the buying public, generally, not only in petroleum, but in all commodities, has become very price conscious in the general retardation of the economic situation; lower wages, reduced incomes. It has made everybody price conscious, and if the merchant satisfies the buyer and he can get it at a cheaper price, again, it is obvious where he will buy. He will buy for the lower price." Record, 325.

52 Examples of these factors are the income of the community, the price of automobiles, and the cheapness of other means of transportation.

${ }^{s}$ The amount of precipitation, general driving conditions, etc. 
follow the cut the aggregate quantity of gasoline purchased will not have been very much increased. The industry as a whole would have suffered; consumers would have gained.

That the non-majors offered something consumers wanted is indicated by the speed with which they grew. Some of them grew very fast indeed. For example, within ten months after he opened a chain of cut-rate filling stations in 1938, Charles E. Austin had become a very important seller of gasoline and a serious threat to price stability. ${ }^{54}$ Austin was actually successful in establishing two large chains, the first of which sold the Zip brand gasoline, the second Joy brand. ${ }^{55}$ He sold the Zip operation, then established the Joy chain. After Austin disposed of it, the Zip chain continued to be an important competitor of the majors. ${ }^{56}$

There were others like him. During the years 1936 to 1940 there were between sixteen and twenty-eight licensed wholesale jobbers and distributors of non-major gasolines in the Detroit area. ${ }^{57}$ Some thirty different "non-brand" jobbers operated at various times during the period. From 1936 to 1940 their sales grew steadily, both in absolute and relative terms. By 1940 non-brand jobbers had increased their gallonage some $40,000,000$ gallons, an increase of 162 per cent. Furthermore, jobbers of non-major gasolines increased their share of the total Detroit market from 6.8 per cent in 1936 to 13.9 per cent

\footnotetext{
"Mr. Raupagh put it this way: "In 1938 Charles E. Austin took out a wholesale distributor's license and started a chain of cut-rate service stations. His gallonage, according to the State's figures, for 10 months in 1938 was over 14,000,000 gallons, and every gallon sold at retail, so that it shows that he has very good consumer or automobile owner acceptance, in order to sell that gallonage, and any time that a marketer can do that in any market or any city the size of Detroit, and immediately take on that much gallonage, that is a serious-it has a serious effect on the business of any major brand marketer. It has a serious effect on all business." Record, 1912. By 1940, Austin's gallonage had climbed to 17,900,000 gallons. Record, 1961. In 1939, he sold 21,607,373. Resp. Exh. No. 57A, Record, 4877.
}

${ }^{\infty}$ Record, 1961.

${ }^{50}$ That major marketers were aware of the importance of the cut price chains Austin established was indicated when Raupagh of Standard Oil said: "In other words, as far as competition is concerned, instead of having one string of cut-price service stations, we now have two from that combination. He operates about 24 [Zip] service stations and operates them directly and his operations have always been on a direct operation. He has a marine terminal and his entire business is founded upon a cut-price basis. . . . It is perhaps the most severe competition that we and other oil companies have in the City of Detroit, as far as the retail market is concerned." Record, 1961-62.

${ }^{57}$ Resp. Exh. No. 38A-38E, Record, 4864-67, gives some idea of the number and variety of jobber or wholesale gasoline operators in Wayne County, in which Detroit is the principal market. The profileration of brands is indicated in Resp. Exh. No. 63A-63C, Record, 4885-86, which shows the name and source of various brands of gasoline sold in Detroit. Resp. Exh. No. 55A-55B, Record, 4875-76, shows jobbers of major (branded) gasolines and their sales from 1936 through 1940. Resp. Exh. No. 57A-57B, Record, 4877-78, shows the names and sales of licensed jobbers distributing non-major brands of gasoline in the Detroit market from 1936 to 1940. 
in 1940, reaching a high of 15.2 per cent in $1939 .{ }^{58}$ By 1939 the market share of non-brand jobbers as a group ranked just below that of the Standard Oil Company, the leading marketer in the area. By 1940, both Standard and the non-brand jobbers had lost in terms of market shares, but Standard had gained somewhat relative to the non-brand jobbers. Furthermore, the gallonage separately allocable to non-major brand distributors undoubtedly understates the magnitude of sales actually made by the non-major brand distributors.59 In every year except 1940 the rate of growth of non-major brand jobbers' sales was greater than the growth in either Michigan or Detroit aggregate gasoline consumption. And, in every year except 1940, their rate of growth was greater than that of any other class of marketer. The non-brand jobbers achieved their greatest rate of growth between 1937-1938, increasing their sales sixty-one per cent during that time. ${ }^{60}$

\section{Retail Price Cutring in Detroit}

Detroit at various times from 1936 to 1940 was the site of such competitive activity in the gasoline market that retail sellers came to regard the condition as a price war. Fortunately, there are available data with which to show the timing, severity and spread of this competitive price cutting.

As part of its regular managerial procedure, Standard of Indiana made periodic surveys of the "prevailing" retail gasoline prices in various cities and other areas, and the number of outlets departing from the "prevailing" price. ${ }^{61}$ Table 2 shows the results of surveys made by Standard of Indiana with respect to the Detroit retail gasoline market. ${ }^{62}$

${ }^{58}$ Consult Resp. Exh. No. 58, Record, 4879.

${ }^{69}$ For example, since commission agents ("yard-haulers") were not licensed as wholesale distributors, their gallonage figures do not appear under the jobber categories. In addition, there was expert testimony that some of the suppliers classified for purposes of this case as major brand distributors sold considerable but indeterminate quantities of gasoline to non-major dealers and distributors. Finally, Detroit sales figures of SoconyVacuum, Texas Company, Sun Oil Company, Shell, Cities Service, Mid-Continent Peters Company (Thiesen-Clemens), Sinclair Refining Company, and Gulf were not available separately. Some of their sales may actually have been made to non-major distributors whose gallonage would not be explicitly allocated to non-major sellers. The non-allocability of those sales therefore tends to understate the importance of non-major gasoline sales. Consult, for example, Resp. Exh. No. 55A-55B, Record, 4875-76.

${ }^{\circ}$ Resp. Exh. No. 59, Record, 4881, shows the relative performance of the different classes of marketers in the Detroit area by comparing the percentage change in their gallonage from year to year for the period 1936-1940.

ar Record, 1941-49, 2022-24, 2124-28.

${ }^{62}$ According to $\mathrm{Mr}$. Raupagh, the prevailing price was the price posted by the majority of all retail gasoline outlets posting prices. Thus the prevailing price was the modal posted price, and was derived from the postings of major and non-major stations. Record, 1945. In theory any modal posted price at which even as few as 51 per cent of Detroit filling stations offered any particular grade of gasoline (third grade, house brand, or premium grade) was the "prevailing" retail price for that grade. But typically the prevailing price 
If we can assume either that posted prices exactly reflect prices actually charged, or that those stations posting the highest prices actually charge the highest prices, and those posting the lowest prices actually charge the lowest prices, then these data may be illuminating. Under those assumptions, they indicate that during periods of slack demand the prevailing price structure is eroded by increasing numbers of price cutting stations, that the prevailing price is lowered in the process, and that further erosion of the price structure may then take place from the previous level. Thus the actual average prices do not abruptly change; they are gradually eaten away. But the prevailing price (because it is not computed) can change sharply if only a few stations go over to the new price. In fact it did change very abruptly.

In any case, the data clearly indicate some important things, and they are confirmed by other data: (1) the trend of retail service station house-brand prices was unmistakably downward; (2) the trend of Standard Oil's tankcar and tank-wagon prices was also downward; (3) the margin between prevailing retail price and Standard Oil's tank-wagon price fell very substantially during 1938, because the prevailing retail price fell more rapidly than tank-wagon prices; (4) the minimum number of stations posting house-brand retail prices below the major price was roughly eighty. According to these data, 1938 and early 1939 were the periods of most intense retail competitive activity, as judged by (1) the low prevailing retail price, (2) dealer margins, (3) Standard Oil tank-wagon prices, and (4) the number of outlets selling below the prevailing retail price. ${ }^{63}$ Whether the prevailing price was falling,

was posted by no fewer than 65 to 70 per cent of the dealers. Record, 2022-24. The prevailing price is therefore not a computed average price. It is the modal posted price.

As a matter of fact, however, since the majority of gasoline sold in Detroit was major gasoline, the "prevailing" price actually tends to be the posted major price. Thus at any point in time, some stations would be posting prices lower than the prevailing price as defined above, and some might be posting prices above that level. But, because the surveys used posted prices exclusively, they may not accurately reflect the extent of actual departures below the prevailing price level.

If posted prices were always equal to actual prices, there would be no problem. But logic and facts indicate that some price cuts will be below posted prices. In periods like that under analysis, it is most probable that if posted prices and effective prices differ, effective prices will lie below posted prices. If stations posting the prevailing price actually sold at posted prices, whereas those posting lower-than-prevailing prices departed from their posted prices, the survey data would underestimate the extent to which the prevailing price was being undermined. If those posting the prevailing price vere cutting below their posted price, and those posting below-prevailing prices were not, then the surveys would over-estimate the extent to which the real prevailing price was being undermined. Similar considerations apply if both classes were departing from posted prices if the amount of such departures differed in the two classes.

as There are two basic explanations for the periodic and very sharp reductions in the number of outlets selling below the prevailing price in 1938. The first of these explanations is essentially political, rather than narrowly economic. In explaining the abrupt decline in the number of outlets shading the prevailing price between February 15, 1938, and March 4, 1938, Mr. Raupagh testified as follows: "The reason for that decrease was 
rising, or constant, there were never fewer than seventy-nine stations selling for less than the prevailing price. ${ }^{64}$

that I believe about that time there was quite a controversy between the gasoline dealer association and the A. F. of L. Union. ... Well, they were trying to organize the service station operators and also the helpers, and in that organization activity, they got quite a number of dealers to join their organization and one of their programs was that there should be no price signs posted at service stations, and they would go around, sometimes as many as ten or twenty dealers would go from one dealer to the other, and just compel him to take his price signs down. I, myself, was threatened on that proposition. ... I think that is the time it happened and, later on there was some bombing of service stations." Record, 2125.

The second type of explanation apparently hinges on the "hunting" movements of a market jerkily moving toward lower equilibrium prices. The sharp decline in stations posting below-prevailing-level prices from the middle of November 1938, to the middle of December 1938, can be explained in those terms. During the period of that decline, Standard Oil lowered its dealer tank-wagon price from 8.8 to 7.6 cents. The amount of cutting below the new (lower) prevailing price then declined. After a time, it increased again.

Table 3 shows for 1937-40 the movements in Standard Oil of Indiana (tank car). jobber prices and Standard's dealer tank-wagon prices. Table 2 shows the number of retail outlets posting for house-brand gasoline prices below the prevailing retail prices. It is interesting to note some of the characteristics of these series. Prevailing retail prices and Standard Oil jobber prices changed eleven times during the period, whereas Standard's tankwagon prices changed nine times. Whereas Mr. Raupagh's second explanation seems logical for the two major declines in the number of stations selling below prevailing price, Tables 2 and 3 at first examination appear inconsistent with that explanation. For example, a marked decline in the number of stations posting prices below the prevailing price seems to have set in after June 14, 1938, a few days before the retail price reductions of June 21. The same sort of thing appears in November 1938. Two possible explanations make these movements consistent with Mr. Raupagh's second explanation. The first depends upon the nature of surveys showing numbers of stations shading the prevailing price. It is highly probable that, in a market like Detroit, the number of stations posting below-prevailing prices would change from day to day, perhaps markedly. The surveys, on the other hand, were not made from day to day, and, indeed were sometimes made irregularly and infrequently. They were made about a week apart in June 1938, but roughly a month intervenes between the observations of November 15 and December 13, 1938. What the surveys show is that sometime between two observations a decline (or increase) took place. We cannot be sure exactly when it occurred, or that other important changes did not occur in the interim. Thus, it is possible that an apparent peak in the number of stations posting shaded prices precedes the real peak, which occurs simultaneously with or after a decrease in posted major prices and/or major tank-car and tankwagon prices, then gives way to a rapid decline. The second explanation rests on the nature of price changes. It may be, for example, that the apparent lead of numbers of stations as compared with prevailing retail (and other) prices is accounted for by announcements of price reductions that precede their effectuation by several days. In such a case, the market may thoroughly discount the changes somewhat before they are officially to take effect.

os Unfortunately, the data do not show whether these seventy-nine stations in March and December 1938 were the same stations, though we may suppose that some of them were. This would be consistent with testimony that certain operators, like the Zip and Joy brands for example, were continuously selling below the prevailing retail level. 


\section{Price Fixing at the Retail Level}

It is not surprising that, confronted by the rigors of competition, retail gasoline dealers banded together to escape them. One form of their efforts to mitigate competitive pressures was the Retail Gasoline Dealers' Association of Michigan. Some of that Association's activities were clearly outlined by the Association itself. In a 1940 editorial, the Association proudly went on record as having initiated, supported, and largely accomplished a "four-point program" to rid Michigan of the evils of unrestricted competition. ${ }^{65}$ According to the Association, it had joined with the Federal Trade Commission in bringing a new order and stability to gasoline marketing. ${ }^{6 B}$

In addition to its efforts to eradicate price discrimination, the Association had pioneered in supporting and enforcing legislation to prevent sales below "cost" as defined by the statute. The statute made dealer cost surveys pre-

${ }^{\infty}$ The four points detailed were (1) the passage of a state fair trade law to prevent sales of gasoline below cost, (2) "Prosecutions under this law educing [sic] sworn admissions by suppliers of subsidies," (3) the initiation of a federal investigation of price discrimination, and (4) "Policing of the market to arrest illegal, below-cost sales of gasoline." Retail Gas Dealers News (Aug. 1940), photostatted in Record, at 76.

That editorial shows that the Association expected to reduce retail competition. In the words of the editorial, "Although the first points of the program have been concentrated in Southeastern Michigan, the ultimate result will benefit the entire State. With the proper follow-up as contemplated by the Association, all of Michigan will be rid of subsidy and chiseling and the illegitimate children of these ogres-price wars and loss sales." Retail Gas Dealers News (Aug. 1940), photostatted in Record, at 76.

Evidently it was the Association that complained to the Federal Trade Commission about alleged price discrimination in the Detroit market, for Bernard P. Costello, President of the Gasoline Station Property Owners' Protective Association of Michigan, wrote that "some time ago the Retail Gasoline Dealers Association of Michigan, Inc., complained to your Commission of these practices. ..." Retail Gas Dealers News (Aug. 1940), photostatted in Record, at 76.

" As the Retail Gas Dealers News put it in March 1941, "It was the impending [Federal Trade Commission] Hearing, as a threat to unfair discrimination that enabled The Association to employ its other legal resources in its united movement that stopped price wars and established legal margins in Detroit in 1939, then in Ferndale, Royal Oak, Pontiac, Lansing, Grand Rapids, Kalamazoo, Battle Creek, and their affected areas. In each area markets remained firm thereafter." (Italics supplied.) Photostatted in Record, at 82. It is interesting and in conformity with the theory presented earlier in this paper that the Association attributed to price discrimination the greatest responsibility for ruinous price cutting. In the words of the editorial, "Use of price discrimination as plain and subtle subsidies to affect prices and control margins has been the root of business unhappiness and tragedy in gasoline retailing, the Association has contended. In this contention it has been backed solidly by the Gasoline Station Property Owners Protective Association.

"Just how much manipulation and strategy has been employed will be explained clearly to convention-attending dealers, who until now have had but a hazy sense of the complications.

"'The root of market upsets and wars is the subsidy,' Executive Director Peck has stated. 'Price discrimination is the source of subsidy, and until we are rid of this unfair, illegal weapon, dealers are in constant danger of unfair competition, price and margin cutting wars, bankruptcy, and business failure.'" Retail Gas Dealers News (March 1941), quoted in Record, at 82. 
sumptive proof of the level of costs, and outlawed sales that did not cover those survey costs. It is abundantly clear that the surveys were undertaken to "prove" the high costs necessary to establish margins desired by Association members. ${ }^{67}$

It is equally clear that the unifying influence of the Association was welcomed as a means of raising prices to levels whose attainment competition would otherwise prevent. ${ }^{68}$ As an adjunct to its other activities, the Association maintained "investigators" to seek out price cutters and bring them under fire from the State Fair Trade Act. ${ }^{69}$

There are many other evidences of concerted action, within or outside the Association, to prevent price competition at the retail level. In 1937, for example, several important Detroit gasoline dealers attempted to eliminate discounting. ${ }^{70}$

"In an editorial entitled "Cry for More Margin Rises," the Gas Dealers News anticipated a projected cost survey by stating: "Michigan gasoline dealers need a new cost survey. During the last two months Michigan gasoline dealers, especially in metropolitan markets, have raised a stronger and stronger demand for additional margins.

"Rising costs, especially of labor, suggest strongly that the 3-cent margin, legally established as a minimum operating figure in a cost survey conducted by The Association early in 1938, is now inadequate. It may be that even dealers operating at 3.3 cents margin and greater are pumping liquid losses.

"Michigan is in the best position of any State to meet the changing conditions. In other States the same sentiment may drive station postings up to cover increased costs, but just a favored or foolish few may upset the structure by chiseling.

"In Michigan, however, the State Fair Trade Law recognizes minimum operating margins and prohibits selling below cost to injure or destroy competition. A cost survey establishes this minimum to the satisfaction of the court." Retail Gas Dealers News (Jan. 1941), photostatted in Record, at 88. The affected dealers collected data used in the survey.

Es "Through the Retail Gasoline Dealers Association of Michigan's program, gasoline margins have been sufficient for operation in stabilized markets everywhere within the sphere of influence of The Association. ... It is the same pattern of The Association that permits easy 'catching up' of the margin to meet greater costs. In other states movement of margin is uneasy, each operator fearing the next as a chiseler of gallonage, and so all may continue to sell at loss." Retail Gas Dealers News (April 1941), photostatted in Record, at 90.

${ }^{\infty}$ According to one report, "Growing memberships in several of the improved markets have contributed sufficient revenue in dues to maintain regional investigators. Policing of the market to obtain proof of illegal chiseling and to report violation of the law is the work of Association investigators.

"Assurance of maintenance of stability depends upon sufficient revenue from dues to keep an investigator in the local market." Retail Gas Dealers News (Jan. 1941), photostatted in Record, at 87.

${ }^{\text {to }}$ After the plan failed because of the defection of some dealers, four important parties to the agreement sent the following letter to their fellows:

\section{Dear Fellow Dealer:}

At a joint meeting held on July 27 th the undersigned dealers agreed to be the leaders in a movement to discontinue all gasoline discounts as a gesture of good faith to the industry, and in a sincere attempt to permanently eliminate the practice.

We were given definite assurance, and it was mutually agreed that by noon of the 
Dealers not only attempted to agree with one another to raise prices, but also tried to get suppliers to police the price structure. Testimony of $\mathrm{Mr}$. Max Biber, General Manager of Citrin-Kolb Oil Company, indicates that dealers supplied by Citrin-Kolb attempted to restrain their supplier from issuing discount cards; ${ }^{71}$ and that Rankin Peck's Retail Dealers Association uncovered and reported to suppliers operators who were undercutting the existing price level. ${ }^{72}$

On some occasions dealers directly approached price-cutting operators to get them to remove signs advertising price cuts. When that technique failed, the dealer groups fell back upon the agencies of government. As the questioning of Chester Martoglio, operator of a Standard Oil station, revealed,

$Q$ : Now, at the end of 1939, in November, did you withdraw those signs and raise your price for Red Crown gas? Well, we will go back before that. . . . How long did you keep them up?

$A$ : Well, I do know this: I worked with a group of dealers to eliminate those signs at that time, and it got to the point where there was only two signs left in our neighborhood.

$Q:$ Where were they?

$A$ : My station and Marvin Goldberg's, and I had to give in first. And then he wouldn't come down, and I think it was one of the assistant prosecutors that had to go down and remove his signs. ${ }^{73}$ [Italics supplied.]

following day all dealers would be on the same program or we would be obliged to go back on the old basis.

We have now waited for Ten Days, and not only have other dealers failed to adopt this program, but competitive conditions have become so bad that it is imperative for us to follow suit.

We are writing to you as a further gesture of good faith and with the sincere promise to co-operate in the future on any program that will be Fair To All.

It has cost us a great deal to pioneer this move, and we sincerely regret that the others did not follow suit.

Record, 4728-29.

$$
\begin{aligned}
& \text { Yours very truly, } \\
& \text { James J. Bright \& Son } \\
& \text { Firestone Auto Supply and Service Stores } \\
& \text { Ned's Auto Supply Company } \\
& \text { Stark Hickey, Inc. }
\end{aligned}
$$

${ }^{71}$ About the discount cards, Biber had this to say: "I remember at the time they were out about three days when a group of our dealers objected to our merchandising in that manner and we called in the cards." Record, 276.

${ }^{72}$ The relevant testimony is as follows: "Q: You said you had personal knowledge of some cutting? A: The knowledge I have would come through Mr. Peck of the Retail Gas Dealers Association, who would call me and say, 'You have got a dealer over there that is cutting prices.' ... A: Well on that information I would go over and talk to the fellow and he would tell me whether he is or not." Record, 281.

${ }^{3}$ Record, 426. In both Chicago and Detroit, price-cutters faced not only legal harassment but some of the techniques of stabilization made famous by Al Capone in the prohibition beer traffic. Nat'l Petroleum News, p. 11 (Feb. 9, 1938). American Federation of 
The testimony of retail gasoline dealer Charles Ruehle further illustrates the tendency of dealers to agree to raise prices, and amply demonstrates the difficulty of making such agreements work..$^{74}$

Howard A. Ferguson, sometime service station operator, testified that he had also participated in concerted attempts to preserve the price level during $1938 .{ }^{75}$ If not always successful, the group of which Ferguson was a member was at least persistent. For in 1938 they acted together to halt the issuance of discount cards by stations supplied by Citrin-Kolb. As Ferguson recalled,

When they first distributed the cards, and then, after concerted efforts of various dealers in making calls to dealers who were discounting with signs out, we were able to clear it up temporarily, and it was just a temporary clearing up on the part of the Citrin-Kolb station, and then they came out with another discount card and

Labor members also picketed Ned's and Stark Hickey, two leading Detroit gasoline retailers. Ibid., p. 11 (May 11, 1938).

In mid-September 1936, The National Association of Petroleum Marketers issued a bulletin showing how gasoline retailers could raise or stabilize prices by blocking the entrance to driveways of price-cutting gasoline stations during rush hours and by other means, and pointing out the need for educating dealers to the destruction caused by price competition. In the words of the bulletin, "It must be shown that any rebating or discounting, secret or open, will result in the destruction of the work being attempted and probably will culminate in a guerilla price-war that will ruin all retailers." Ibid., p. 17 (Sept. 16, 1936). On August 13, 1937, organized retail gasoline dealers in Detroit took direct action to discourage their price-cutting brethren. Pittsburgh dealers acted similarly. As one report explained: "Detroit and Pittsburgh dealers operated caravans of automobiles to block the driveways of discounting stations and sought warrants under the new laws to prosecute retail gasoline operators said to be violating the new statutes." Ibid., p. 17 (Aug. 18, 1937).

But neither driveway blockades nor missionary work among wayward brethren was successful in preventing retail price cuts: "It was learned that, on Aug. 11, about 17 of the largest gasoline retailers in the city met with Peck, who made an effort to get these operators to again cut out discounting. According to one operator, the effort was unsuccessful. ..." Ibid., p. 27 (Aug. 18, 1937).

"Under the questioning of Cyrus Austin, attorney for the Commission, the story developed as follows: "A: In July of ' 38 we raised the price. There was some of our friendly competitors came around and said it was a bad situation, which we agreed with, and we agreed to raise the price. Q: Who were those friendly competitors? A: Well, there was Mr. Ferguson and Chet Martoglio and-I just don't remember; that is two of them. There were about six or eight, I should say. Q: And did you then raise your price back to what it was in February? A: Yes, we did. . . Q: And how long did you keep that price in effect? A: It was about the whole month. Not the entire month, but very close to it. $Q$ : And what was your gallonage for July? A: $19,311 \ldots$ : . What was the gallonage for the previous month? A: 32,439 . Q: Did you again reduce your price? A: We did. Then it became prevalent all over the city. Almost everybody went into it. $Q$ : You mean the price cutting? A: The price cutting. Q: Did you lower your price again at the end of July? A: We did, yes. Q: Back to where it was in June? A: That's right." Record, 461-62.

${ }^{5}$ As he put it: "I said myself and 'Curley' Knowles, the operator of the Cities Service Station across the street, attempted to prevail upon the White Star dealer to stay along in line with us. He refused to do so, and then Mr. Knowles dropped his price, and I believe that was in February, and it caused such a tremendous loss in gallonage that we were forced to drop our price in March." Record, 597. 
distributed them throughout the neighborhood; not only discounting on gasolines, but motor oils also. ${ }^{76}$

Although apparently the prevailing price would ultimately be undermined, gasoline marketer Max Biber felt he could definitely credit the dealer association with its establishment. ${ }^{77}$ Even so aggressive a seller as Ned's Auto Supply evidently came to be influenced by the strength of the dealer association. In answer to Cyrus Austin's questions, Charles H. Gershenson testified as follows:

$Q$ : What do you mean, when the price change comes through?

A: When we are advised of the price increase and what Mr. Peck's association tells us at what we have to sell it, that's what we do rather than submit to his tactics.

$Q$ : Is that where you get your information from, as to the price; Mr. Peck's association?

A: That is where we had to, in the last year and a half, if we want to be safe. We don't like his tactics, but rather than disagree with him, we sell at his price. I mean that in all seriousness on my account.78

Whatever the success of the retail cartel in completely stopping undercover price cutting, it evidently did succeed on occasions in greatly reducing the amount of open price cutting at retail. In doing so it received the aid of trade unionists. In explaining the decline in the number of stations openly posting prices below the prevailing major gasoline prices in March, 1938, Mr. P. A. Raupagh, Standard Oil representative, said:

In March the number of stations, according to the surveys we had made, had dropped down to 119 that were selling below the prevailing wholesale [sic] prices of major brand dealers, and that was because of the activity of taking down signs. There was considerable union activity in 1938. By union I mean the A. F. of L., who got busy and made a concerted drive to have all dealers remove their signs. ${ }^{79}$

What Raupagh meant by union activity was apparently a working arrangement between the filling station operators and the American Federation of Labor.80

\section{: Record, 597.}

7In Biber's words: "Well, I would say since 1937 and 1938 the prevailing retail price here in Detroit has been determined so largely by the dictates of the Gasoline Retailers Association. They have told their dealers that they ought to have a certain margin, and that is the margin they ought to sell at, and anybody selling under that margin is either approached by members of the Association or otherwise approached through the oil companies, through the suppliers, to meet that price. It is a price they said gasoline should be sold at." Record, 1784.

${ }^{\text {is }}$ Record, 1870.

"79 Record, 1905.

${ }^{80}$ In Raupagh's words: "A: Well, they were trying to organize the service station operators and also the helpers, and in that organization activity, they got quite a number of dealers to join their organization and one of their programs was that there should be no price signs posted at service stations, and they would go around, sometimes as many as 
The maintenance of cartels is rendered immensely difficult by changes in the costs of those who would participate in them, especially where costs differ. And price discrimination guarantees that, so long as it persists, costs of merchandise will differ among the sellers. When several, or many, separate firms offer closely substitutable commodities for sale and unilaterally discriminate in price, they will not only involve themselves in price rivalry, but, because they create cost differences among their reseller customers, also engender competition at the lower level. Because price cutting can be more secret when it is discriminatory, unilateral price discrimination tends to break down cartels as well as to disrupt a non-collusive oligopoly equilibrium. In strongly opposing the practice of selling gasoline to jobbers and tank-wagon dealers at different prices, Paul Harrison, Western Regional Manager of the Sun Oil Company said,

My opinion is that it creates a very difficult competitive condition by reason of the fact that some marketers are able to buy at a lower cost than others, and it is the usual practice that the preferential buying leads to a lower retail price either openly or though one means or another of discounting. . . . In my opinion, it forces the other dealers to sell at a lower retail price, either by direct price posting or by some means of discounting, in order to meet the competition established for them in their respective trade areas. ${ }^{81}$

I attribute it, the beginning of it, in nearly all cases, to the fact that some marketer has got a preferential cost; that is, a preferential buying price, and he is anxious to expand, and he has the power to do so through having the wider margin of profit, gross profit to work with, and he wants to get more gallonage; so he does something to reduce his price to the public and that is always the start of those price-cutting orgies that we get into periodically. 82

\section{Standard's Jobbers as Gasoline Buyers}

In markets of "few" sellers competitive pressures will very likely be concentrated-at least in the beginning-at certain key peripheral areas. Rivalries will tend to be manifested most vigorously at a few sections of the market at a time, though we may predict that they will come to pervade the whole market ultimately. Competitive pressures in the 1930's were often first concentrated upon the business of gasoline jobbers. Standard Oil of Indiana's role in this struggle for trade is revealed most strikingly in relations with its four remaining jobbers-it had already lost four of them ${ }^{83}-$ Ned's Auto

ten or twenty dealers would go from one dealer to the other, and just about compel him to take his price signs down. I, myself, was threatened on that proposition. Q: Well, did that happen just at this particular time? A: I think that is the time it happened, and, later on there was some bombing of service stations." Record, 2125.

${ }^{81}$ Record, 320-23.

${ }^{82}$ Record, 343.

${ }^{8}$ According to Mr. Raupagh, Standard Oil lost three jobbers (Carnick, Middleton Oil Company, and Dick Lock) to rival major companies, and one (Holzbaugh) because of business failure. Carnick left Standard about 1933 or 1934 to buy from Shell, then went 
Supply, Citrin-Kolb, Stikeman, and Wayne Oil Company. It will therefore be helpful to explore in some detail the history of the relationships between Standard Oil of Indiana and these four resellers of its products.

Ned's Auto Supply Co. Ned's was a large multiple-outlet merchandiser of electrical appliances, sporting-goods, hardware, auto supplies, paints, and gasoline and other petroleum products. ${ }^{84}$ The business was originally established by Ned Gershenson. He began retailing gasoline and other petroleum products in 1918 by installing a pump in front of his bicycle shop. He began by selling Standard of Indiana products and never abandoned them. After his death, Ned's continued to be run by the Gershenson family and remained a Standard Oil dealership. ${ }^{85}$ The business prospered, and Ned's came to be a large retailer of gasoline and petroleum products as well as of tires and other merchandise. ${ }^{86}$

Aware of its growing stature as a gasoline retailer, and familiar with the growing importance of jobber distribution in the area, Ned's management apparently grew restive. ${ }^{87}$ Economic conditions in the oil industry were such that large gasoline dealers could readily achieve "jobber" status and get tankcar prices. For from about 1930 to 1936 Ned's received a number of offers from rivals of Standard of Indiana. The first of these developed about 1930 from an officer in the Argo Oil Company, which had only recently expanded from fuel oil into gasoline distribution. ${ }^{88}$

Beginning about 1930, and periodically thereafter, Messrs. McLean and Dworman of the Red Indian Oil Company solicited Ned's business. ${ }^{89}$ Al-

to Gulf Oil, under which arrangement Carnick got a tank car price without the need for maintaining his own bulk plant: he hauled out of Gulf's bulk plant. The Middleton Oil Company threatened to leave Standard to accept a lower price from Shell and, when they didn't receive more favorable terms from Standard, accepted the Shell offer in 1933. Dick Lock left Standard about the same time to accept a more favorable offer from Gulf. Record, 1913-15.

st Record, 1796.

${ }^{85}$ Record, 1795.

${ }^{8}$ By 1940 Ned's total gallonage was about 4,200,000 a year. Record, 1800 .

${ }^{87}$ As one member of the family put it: "Part of this goes back over ten years but starting with about-oh, subsequent to-right around 1930, was when our company, consistent with the way we did business, generally started to approach different suppliers, as well as entertain, at least, conversation from them relative to our buying gasoline on better than a tank wagon basis.

"The method of distributor distribution was becoming more prevalent in Detroit. . . " Record, 1803.

${ }^{88}$ Argo offered to sell Ned's Dixie gasoline in tank-wagon quantities at a price 1 cent per gallon lower than the prevailing tank-wagon price. (Argo later became a Shell distributor.) Record, 1804. The Gershensons concluded that they did not want to drop the Standard Oil products, and the Argo offer died.

${ }^{80}$ Red Indian sold Phillips 66 gasoline at that time, and offered it to Ned's for 1 cent per gallon less than tank wagon, delivered, or $1 \frac{1}{2}$ cents off tank wagon if Ned's picked it up at the Red Indian bulk plant and hauled it for themselves. Record, 1804-5.

Gershenson apparently understated the amount of the discounts below tank-wagon 
though Phillips 66-a widely advertised product-had a public acceptance greater than that of the gasoline Argo had offered, Ned's still preferred Standard. Ned's did not accept the Red Indian offer. ${ }^{90}$

Not only did Ned's listen to whatever offers various suppliers made; it also actively solicited them. An example is the negotiation with the Texas Company. ${ }^{91}$ After the discussion with Mr. Dodge of the Texas Company,

price. As he later testified, "We had a choice of taking delivery in one of two ways: Either picking it up ourselves at their bulk plant terminal, which would give us a margin of 1.75 or having them deliver the gasoline to our retail stations in their tank trains. I don't know what methods they were going to use to get it to our stations, but our margin would be 1.5 off the tank wagon price." Record, 1832. See also the letter from I. B. Dworman of Red Indian to Gershenson, Resp. Exh. No. 47, Record, 4869.

${ }^{80}$ According to Charles Gershenson, "at that time the cent a gallon off tank wagon was quite a prevalent jobber's price ... from my knowledge in the industry I knew we could get that from any one of several sources." Record, 1805.

${ }^{81}$ In the words of Charles Gershenson, "At that time, this was about in May or June of 1933, the Firestone Tire and Rubber Company had contracts with Texaco and-I know it was Texas and Cities Service and one other supplier-I am not sure who they were, and they had completed a bulk plant here and were buying gasoline at $4 \phi$ a gallon on house brand gasoline off tank wagon prices and I approached the local representative of Firestone and told them we would like to buy gasoline on the same basis that they were buying it and had some correspondence with Akron where an appointment was made for me to meet Mr. Dodge, who was then vice-president, I believe, and sales manager of Texas and I met Mr. Dodge in Akron. This was in June of 1933. . ." Record, 1806. Gershenson was seriously considering a change unless he could get better terms from Standard. He had at least one detailed discussion with Dodge of the Texas Company. Record, 1807.

Although Gershenson told Raupagh that they "wanted to make some other connection," evidently the family would have preferred to continue its association with Standard Oil. Raupagh apparently sensed their attachment to Standard, for he was able to retain their custom. In Charles Gershenson's words, "[Raupagh] said we would have to start building up a clientele [sic] on a competitive brand of gasoline. In other words, that the loss of volume from Standard to some competitive brand would more than offset the additional margin we would make on the other brand, so that it would be a stand-off, we would have to develop new customers, and $I$ was inclined to think he was right. That is how he kept me satisfied; not only inclined to think that but that represented our sincere business judgment. What we were trying to do was to get a lower price from Standard Oil Company so that we could retain that good will and customer contact and, at the same time, make another margin of profit and there was another factor in there-I don't know how important it is-was the fact our father had started that contract with Standard Oil Company. We attached some importance to that and we didn't want to change unless we had to do that. It had been a tradition. Our father started the Firestone contract. Our father passed away, in the meantime. We just felt, emotionally, maybe, it was a superstition, that the last thing we wanted to do vas change from the Standard Oil Company." (Italics supplied.) Record, 1809-10.

Raupagh confirmed these reasons when he testified as follows: "Now, specifically as to why I have been able to hold them: I believe that in the first place they have handled Standard Oil products since they started in business. It seems to be a sort of tradition with them; that their father started the business. As $I$ understand it, it was a little pump in front of a bicycle shop.

"The boys carried on the business after that, and launched into the tire line quite heavily.

"Red Crown is just part of Ned's family, you might say. 
Gershenson met Raupagh to air his dissatisfaction with the tank-wagon price from Standard, and to inform him they were negotiating with other suppliers. At this time and after the other offers made over two or three years, Raupagh was able to convince the Gershensons that it would be undesirable for them to change suppliers. That Ned's continuously attempted to improve its terms with Standard is indicated by Charles Gershenson's statement that "from 1933 to 1936, I was going to say in this way, that until we got the additional half cent that it was a constant tug of war between Standard Oil and us."

Whether they had actually come to the point of changing suppliers, or simply wanted concrete offers with which to bargain better terms from Standard, the Gershensons continued to discuss offers with Standard's rivals. In 1933 or 1934, Charles Gershenson talked with a representative of Shell about becoming Shell's exclusive jobber in Detroit. Shell offered Ned's a price two cents lower than the tank-wagon price, but Ned's finally declined it. ${ }^{93}$

Although Ned's had not acted on any of the previous offers, by late August 1936, the Gershensons were willing to offer Standard an ultimatum. On August 27, 1936, Charles Gershenson, referring to the Red Indian Oil Company offer, wrote Raupagh the following letter:

This is to advise you that a competitive major oil company recently submitted to us a gasoline contract carrying a substantially larger margin of profit than we now enjoy from your company.

It is our present intention to act upon this offer and accept same. ${ }^{94}$

\footnotetext{
"There is another reason why I think I have been able to hold them. It is characteristic of the Gershenson family that they place a great deal of stock in their mother. The mother has always been very set in her ways, as far as Standard Oil is concerned, and as far as Red Crown gasoline is concerned. They listened to what she says. I don't believe that I would have held them if it hadn't been for that, because-maybe I shouldn't say this-but sometimes the relations haven't been as nice as they should be, when these competitive offers would come up." Record, 2002.
}

${ }^{92}$ Record, 1809.

${ }^{2 s}$ According to Gershenson, "[a]t that time they [Shell] were actively coming into this market. ..." As is often the case when a firm is entering a new market, Shell chose as an important element of its penetration into Detroit the acquisition of the business of a jobber already established there. This is called in the trade "jobber raiding." Shell offered 2 cents per gallon off the tank-wagon price, "which was then the prevailing differential between tank wagon and tank car," Record, 1810, and tried to overcome Gershenson's reluctance by saying that someone else would accept the offer if Ned's did not. Gershenson again pointed out his reluctance to leave Standard. Sometime during the period in which Ned's was discussing this matter with Shell, Gershenson reported to Raupagh that he had received a more favorable offer from a major supplier, but did not succeed in lowering Ned's price. In the meantime, Stark Hickey, a Detroit automobile dealer and large gasoline dealer, signed up as Shell's Detroit jobber. Record, 1811.

Resp. Exh. No. 45, Record, 4868. See also Record, 1813 ff.

Gershenson's characterization of Red Indian as a supplier of major brand gasoline was 
After receiving the letter, Raupagh forwarded it to Amos Ball, General Manager of sales, in the Chicago office. ${ }^{95}$

Shortly after Raupagh got the written ultimatum, he and Gershenson met to discuss the matter. If Raupagh had expected again to dissuade Ned's from getting a better price or ending its relationship with Standard, the meeting must have surprised and disappointed him. Ned's management demanded to talk with someone in Standard's main Chicago office. ${ }^{96}$ Raupagh knew the situation was serious. In Chicago Gershenson discussed the matter with Mr. Lewis, a representative of Standard of Indiana. Lewis was familiar with Ned's importance as a gasoline reseller, ${ }^{97}$ and listened sympathetically to their position. Gershenson said they would stop buying from Standard unless they got a price at least one cent per gallon lower than they were paying.98 Whereas Lewis did not immediately accede to the ulimatum, he encouraged Gershenson. ${ }^{99}$

A day or two later Raupagh got in touch with Gershenson to tell him that Standard would give Ned's a reduction of one-half cent per gallon below the price they had been paying. Gershenson was mollified but not pleased.100 Satisfied or not, Gershenson accepted the Standard offer, and from Septem-

accurate. According to him, "The Red Indian Oil Company sells Fleet-Wing gasoline, which is Standard Oil Company of Ohio. The reason that is consistent is we feel we would suffer least in volume if we changed from Standard Oil of Indiana to Standard Oil of Ohio, because in our advertising we can say that it is Standard Oil Company." Record, 1816.

${ }^{25}$ Record, 1988.

${ }^{x}$ According to Gershenson, "I told him that this letter was an ultimatum, that we had definitely made up our mind to accept a competitive offer unless we got a better deal from the Standard Oil Company, and I asked for the privilege from Mr. Raupagh to go down to Chicago, going over the heads of the Detroit office. That if we were going to break our relationship with the Standard Oil Company, we wanted the satisfaction of being turned down by the home office." Record, 1813-14.

97 That he should have been familiar "with the account" may be explained by the fact that Ned's then was selling gasoline at the rate of over 2,000,000 gallons per year. Record, 1814.

${ }^{83}$ Record, 1814. In arriving at that transfer figure, Gershenson said he was thinking of the Red Indian offer, and an offer of Hicock Oil Company to sell Hi-Speed gasoline for a price lower by one cent than that Ned's was paying. Record, 1815.

${ }^{90}$ As Gershenson recalled, "Mr. Lewis was very optimistic. He told us not to be too hasty. We had been a good customer, and he gave me the usual-they didn't want to lose our business-they would do the best they could to meet our competitive situation, and the lost gasoline- he kept telling us, through changing brands we had no way of knowingthat was their strongest argument, and they used that, but, as I say, he was very optimistic about their being able to do something on it. ..." Record, 1815.

${ }^{100}$ As he summed up his feelings, "I know how we felt. We accepted it as better than nothing at all, but we weren't satisfied-we wanted tank car at that time, or a better tank wagon price. We wanted a cent a gallon off the tank wagon price." (Italics supplied.) Record, 1815. 
ber 1, 1936 to March 1938 Ned's received tank-wagon deliveries at one-half cent per gallon below the tank-wagon price.101

Apparently no one was more keenly aware of Ned's dissatisfaction than Raupagh, who saw the Gershensons rather frequently. After "at least 12" conversations with them about competitive offers that were available to Ned's, and related matters, Raupagh concluded that the one-half cent concession was not enough to retain Ned's business. In his words,

I definitely made up my mind that if we wanted to retain the business of Ned's Auto Supply Company, it would be necessary for us to sell them in tank car quantities at tank car prices. They, of course, would have to equip themselves with a bulk plant, and so on and so forth. ...

They, themselves, told me that they could get not only a better price from the Red Indian Oil Company, but also from other companies at tank car prices, and, knowing the market as $I$ know it, I was convinced that they could, also. [Italics supplied.] ${ }^{102}$

By February 1938, the Gershensons' dissatisfaction with their gasoline price had become acute. On February 14, Charles Gershenson wrote the following letter to the Detroit office of Standard of Indiana:

For some time past, we have felt that our volume entitled us to tank car prices. Our ideas on the subject were given added impetus and confirmation when, as you remember, we were approached in August, 1936, by representatives of the Red Indian Oil Company with tank car prices, at truck delivery and Shell Petroleum with a better deal; both with a view to changing to their respective brands. Because of our long association, we naturally advised you of the situation and the ensuing discussions resulted in our letter agreement of August 27, 1936, and your promise to give consideration to our receiving tank car prices at an early date.

Present plans for expansion, when consummated, will result in a substantial increase in our volume, and we feel that in view thereof, to expect us to continue on the present basis, involves an unreasonable sacrifice on our part.

We, therefore, request that you give immediate consideration to the desirability of continuing as our gasoline supplier, but at tank car prices. Otherwise, we shall be compelled to re-open negotiations with other suppliers. ${ }^{103}$

As a result of this letter, Ned's and Raupagh reopened negotiations. During their negotiations, Charles Gershenson relied upon the previous offers from Red Indian, Shell, and the Texas Company to prove to Raupagh that Standard was in danger of losing Ned's custom. Gershenson was not bluffing. $\mathrm{He}$ apparently wanted to be sure he still had a good alternative offer, for shortly before bargaining with Raupagh he satisfied himself that the Red Indian

${ }^{101}$ Record, 1816.

${ }^{202}$ Record, 1895-96.

${ }^{100}$ Resp. Exh. No. 46, Record, 4868-69. 
offer remained in effect. ${ }^{104}$ Fortified with this knowledge, Gershenson delivered another ultimatum. It was persuasive. ${ }^{105}$ Ned's became a Standard Oil jobber and received the tank-car price.

Citrin-Kolb. In about 1920 Jacob Citrin bought a Detroit filling station and went into the gasoline business. About three years later he entered into a partnership with Kolb, who owned an automobile accessory business. ${ }^{108}$ In the beginning, Citrin sold gasoline supplied by the Lincoln Company, as well as the Standard Oil Company, but changed exclusively to Standard Oil Products about 1923.107 As their business grew, Citrin-Kolb's management began to feel that, because of their volume, they could get better than the tank-wagon price they were then paying. ${ }^{108}$ By that time Citrin-Kolb owned and operated several retail filling stations. ${ }^{109}$

The first supplier Citrin-Kolb contacted was the Paragon Refining Company. Citrin-Kolb knew that one of Paragon's customers was Waco, a local gasoline jobber. ${ }^{110}$ Citrin found out early in the Paragon discussions that, to bargain successfully for tank-car prices, they would have to acquire bulk plant facilities. ${ }^{111}$

${ }^{10}$ Dworman assured him that the offer stood. As Gershenson testified, "I asked him whether we could buy gasoline from them on a tank car basis better than tank wagon, and he said, 'When you are ready, we will sell you.' " Record, 1820.

${ }^{105}$ According to Gershenson, "I satisfied him [Raupagh] that we meant business this time. We were really going to change, and I feel and know that as a result of that, that we were put on a tank car basis." Record, 1821.

Raupagh also had further reasons for supposing that Ned's could make a more advantageous gasoline arrangement than Gershenson had recalled in his testimony. For Raupagh recalled some offers that Gershenson did not mention in his testimony. In addition to the Firestone-Texas Company, Red Indian, and Shell offers, Gershenson had also reported offers from Sun Oil and Gulf. Raupagh recalled these reports in considerable detail. Record, 1998, 2000. Finally, Raupagh vaguely recalled many other offers that had been made to Ned's by Standard Oil's rivals. In his own words, "I know that according to conversations that $I$ have had with them over a period of ten years that they have had many more offers and that many more offers they have told me about ... there has never been a time since I have been here that they haven't been able to purchase gasoline at less than the dealer tank wagon price, any time they wanted to take advantage of offers that they had." Record, 2001.

${ }^{100}$ Record, 1244-45. At the time Citrin testified, the Citrin-Kolb partnership also included Citrin's father.

${ }^{107}$ Record, 1246. According to Jacob Citrin, "the reason for purchasing gasoline from the Lincoln Oil Company was that at the time they owned a company station on Warren and 24th and they offered that station to us at a lew [sic] rental as a consideration of purchasing their gasoline." Record, 1248.

${ }^{108}$ As Citrin put it, "Having had a few service stations at that time, and knowing that there were jobbers who had as many service stations or less than we had, who had been buying on a tank car basis, we had started to negotiate many connections in order to obtain tank car prices and we found that we had to have a siding and tank facilities." Record, 1249.

${ }^{109}$ Record, 1247.

${ }^{110}$ Record, 1249.

${ }^{111}$ As Jacob Citrin recalled, "A [Paragon] representative contacted me, and, as I recall, at that time, there were several jobbers, who $I$ had related to this representative, and I 
Without acting further on the discussions with Paragon, ${ }^{112}$ Citrin-Kolb arranged to share the bulk plant facilities of the Carnick Oil Company, a Detroit jobber. ${ }^{113}$ They then began to feel out the Standard Oil Company. ${ }^{114}$ Sometime between 1926 and 1928, Standard extended the tank-car price to Citrin-Kolb. ${ }^{115}$ Shortly after Standard began deliveries on the new basis, Raupagh discovered that Citrin-Kolb did not have its own bulk plant, but shared facilities with Carnick.116 Raupagh explained that Standard would stop supplying Citrin-Kolb unless they obtained their own bulk plant forthwith. Citrin-Kolb objected, ${ }^{117}$ but Raupagh was adamant, ${ }^{118}$ By early 1929 , Citrin-Kolb had bought a lot and erected a warehouse and three 20,000 gallon tanks, an office and filling station on it, and installed a two-car railroad siding to serve the installation. ${ }^{119}$ During and after that construction, Standard continued to serve Citrin-Kolb on the tank-car basis. From the time they first became tank-car buyers until about 1935, Citrin-Kolb sold exclusively at retail through its own service stations. About that time, how-

pointed out that those jobbers not having any more outlets than we had, were buying in tank cars, and we felt that we were going to expand and that we wanted to negotiate a deal....

"The first he told us that we would have to have facilities and saw no reason why we shouldn't be able to buy in tank cars." Record, 1253. At that time, Citrin said, the differential between tank-car and tank-wagon prices was "between two and three cents." Record, 1254.

112 "[W]e weren't sure at that time whether we wanted to buy from them. We were just sort of feeling our way." Record, 1255.

${ }^{113}$ Record, 1247, 1255.

${ }^{174}$ In Jacob Citrin's words, "We negotiated this storage with Carnick and went to Standard on the basis that we felt we had sufficient gallonage that we wanted to combine those outlets and that we were going to buy in tank car lots." Record, 1255.

${ }^{115}$ Citrin's inability to provide the precise dates for this early period of the firm's history is accounted for by loss of records. As Citrin explained, "Well, having started off in sort of a small way, and moving several times, we just sort of lost the records that far back." Record, 1255.

${ }^{110}$ Record, 1256. Carnick was a jobber for a major rival of Standard.

${ }^{117}$ Standard's position put Citrin-Kolb in an unenviable position: they were committed to occupy the facilities with Carnick for a fairly extended time. Record, 1256.

${ }^{118}$ Jacob Citrin recalled the situation in these words: "He said, Now here: Assuming that we would let you handle the gasoline on the basis where you are now getting it with Carnick in the same storage. On that basis nothing would stop any dealer or bunch of dealers who would get together and acquire one tank and ... they would want to buy in tank car lots,' so they said, 'if you are a distributor and you want to continue to buy in tank cars, you must make an investment, have your own trucks and make your own deliveries,' and they certainly wouldn't change their attitude at all. It was either get the storage or else they were going to stop selling us." (Italics supplied.) Record, 1256.

119 Record, 1256-57. On April 21, 1941, Max Biber, general manager of Citrin-Kolb testified that Citrin-Kolb's investment in bulk plant facilities amounted to about $\$ 85,000$ out of the firm's total investment of some $\$ 250,000$. Record, 852 . 
ever, they became wholesalers almost entirely. ${ }^{120}$

Whereas they continued to be Standard Oil jobbers, Citrin-Kolb knew that jobbers for other companies operated on a wider margin. ${ }^{121}$ Though their relationship with Standard was a good one, Citrin-Kolb did not fail to consider alternative offers. Some of them were so favorable that Citrin very nearly left Standard. ${ }^{122}$ Citrin used the last offer, that from Aurora, as he had

${ }^{220}$ As Jacob Citrin explained: "Having acquired several . . . retail dealers-we found that we would be required to decide whether we were to operate either as a retailer or a wholesaler." Record, 1257.

121 "We knew that the other jobbers were getting a better price than we were." Record, 1258. The "other jobbers" Citrin referred to were the Lincoln Oil Company, Great Western Oil Company, Waco, Savin Oil, Zip, Wilson Oil Company and Indian. Record, 1253. Citrin's reasons for preferring to buy from Standard are markedly similar to those advanced by Charles Gershenson. Citrin summarized their position in this way: "First of all, when we started at Fenkel and Dexter, that station having been somewhat one of the first stations down in that section, we started to do a tremendous business there, and, of course, we were sort of attributing a large part to the products we were selling, and we just felt that we would be better off to continue with Standard inasmuch as we had already established a certain amount of business in the stations we had." Record, 1258.

${ }^{122}$ In 1930, for example, they entered into negotiations with representatives of the Wilson Oil Company, sole distributors of Hi-Speed gasoline, that eventuated in an attractive although rather intricate offer. Record, 1259-60. Raupagh's testimony confirms that CitrinKolb reported an offer from the Wilson Oil Company and that the Highland Oil Company had accepted what was thought to be a similar proposition. As to the price Wilson offered, Raupagh had this to say: "They were $6 \frac{1}{2} \&$ off the retail price established by the Standard Oil Company, which was a very advantageous figure, because that means about $3 \&$ below the dealer tank wagon price in 1930." Record, 2003-5.

Shortly after the Hicock discussions, Shell Oil approached Citrin-Kolb with an offer. Even though Citrin told Raupagh that Citrin-Kolb might leave them, Raupagh did not make any concessions. But he evidently argued convincingly, for Citrin testified: "Well, there were so many different conversations that I had with Mr. Raupagh. Every time we would have a different offer, I would go to him and point out the advantages and it sort of got to be a regular sales talk between one time and the other. In fact I remember walking out of there with the idea, 'Well, there again you have done a good job of talking me out of leaving you, or quitting this company.' It seems all the conversations were just continuous salestalk on Mr. Raupagh's part." Record, 1273.

Early in 1936, a representative of the Gulf Oil Corporation called on Citrin to solicit his business. As Jacob Citrin saw it, Citrin-Kolb's volume was an important factor leading to the Gulf offer. Record, 1279. The Gulf offer provided a tank-car price of $1 \frac{1}{2}$ cents below tank-wagon, and additional substantial, although indirect advantages. Record, 1279-80.

In 1936 Citrin-Kolb's negotiations with the Texas Company very nearly eventuated in a five-year contract. The Texas Company would have guaranteed them a price $5 \frac{1}{2}$ cents below retail price for a five-year period and would have provided certain advertising allowances, as well as paint and globes for the stations that they supplied.

In 1939 Roy Fisher of the Argo Oil Co., a Marathon jobber, called on Jacob Citrin and attempted to obtain his gasoline business. Record, 1295. It is significant that, in virtually every case of an offer reported in this proceeding, sellers are very importantly concerned over the volume done by prospective purchasers. In the case of Roy Fisher, Citrin recalled that, "at first he sort of admired the amount of business we had and the volume." Record, 1297. Citrin-Kolb never acted on the Argo offer. Record, 1300-1301.

In 1940, and subsequently, representatives of the Aurora Oil Co. attempted to get CitrinKolb's custom. Aurora offered to supply Citrin-Kolb gasoline at 2 cents per gallon less than the tank-wagon price. Record, 1308. 
used the others: it became a lever to obtain more favorable terms from Standard. Citrin indicates that this approach was his usual one when he said,

[E]ver since we have been able to buy or could have bought gas cheaper, we continually endeavor to get them to increase the margin to put it in line with the competitive companies. ${ }^{123}$

But, try as it would, Citrin-Kolb was unable to extract further concessions from Standard. According to Citrin, Citrin-Kolb was still considering the Aurora offer as of April 26, 1941.124

The Wayne Oil Company. Elmer Ledbetter until 1931 had been treasurer of a hot water heater company. In that year he resigned to go into the gasoline business. He bought one filling station in Detroit and purchased gasoline from Standard Oil on the tank-wagon basis. ${ }^{125}$ Later in the same year he bought two more stations. By July, 1935, he had some twelve outlets in operation and did a total volume of about $1,000,000$ gallons a year. Some time in 1935 Ledbetter leased a station from the Highland Oil Company, Detroit supplier of Hi-Speed gasoline. Highland provided gasoline to that station at a price one cent below the prevailing tank-wagon price, and offered to supply all of Ledbetter's stations on the same basis. ${ }^{128}$

Although in August 1935, Wayne obtained the jobber classification from Standard and thereafter paid the tank-car price, ${ }^{127}$ it was not until 1938 that the Wayne Oil Company went one hundred per cent Standard Oil. ${ }^{128}$ Wayne did not get the tank-car price from Standard without bargaining for it. Ac-

1203 Record, 1310.

${ }^{124}$ Record, 1310. With respect to his discussions with Raupagh, Citrin said, "I believe I again talked to him about helping out on the equipment or, at least, taking the burden off, because that is quite a costly burden. He again refused, and that's about all we talked about." Record, 1310.

${ }^{125}$ Record, 983.

${ }^{128}$ Record, 2011-12, 984-85. Thus Ledbetter was paying Standard the tank-wagon price for gasoline it supplied, and paid 1 cent per gallon less to Highland. The record suggests that in the period 1933-35 Ledbetter was simultaneously purchasing gasoline from Highland, Sun, Standard and Gulf. Record, 1168.

${ }^{12 \pi}$ It did not obtain the tank-car price on Solite with Ethyl until July 3, 1936. Record, 574. Although Ledbetter did not explicitly explain the connection between the events, it is interesting that, about August 1935, Highland then altered the terms on which it dealt with Wayne. In Ledbetter's words, "They cut out the concession they were giving me." Record, 1169.

Between 1933 and 1939 Wayne did not directly operate the stations it owned. Record, 1170. In Ledbetter's words, "I purchased the gasoline or guaranteed the account of the dealer ... . or rather I believe that the contract for the purchase of gasoline was in the name of Wayne Oil Company, and my present idea is that I resold it to the dealer at my cost, which is the way that I handled all my operations from about 1933 up to 1935 . They were all sub-leased on a profit sharing lease." Record, 1167-68. "I would say after 1933 at the time I leased all of these stations out, sub-leased all of these stations, leased on these profit sharing leases, I wasn't even a retailer. I was just a landlord, as I figure it." Record, 1169.

${ }^{108}$ Record, 1174. 
cording to Ledbetter, "I had been trying to get Standard Oil to let me go on that basis for probably two years prior to that time." 129 Although he did not have a bulk plant or hauling facilities when he began to purchase from Standard on the tank-car basis, he knew he could obtain them immediately and in fact did so. ${ }^{130}$

Whether he received offers only recently, or simply did not remember the earlier ones, Ledbetter testified only with respect to offers made in 1940 or later. In his words,

Well, the first one that I can testify to, of course, is fairly recent, because I don't remember those things too long definitely. But on December 10,1940, Wayne Oil Company was offered 80 octane gasoline delivered by transport truck at our bulk plant at the price of 6.1 cents per gallon without tax. ${ }^{131}$

This offer came from Howard J. MacGready, a representative of the Aurora gasoline company. The terms were one-half cent per gallon more favorable than Standard Oil's tank-car price on house-brand gasoline, and the Aurora gasoline was several octane points higher in quality. Although he did not accept the offer, Ledbetter reported it to Standard..$^{132}$

Some three days after the Aurora offer, Ledbetter received another one. Mr. Stikeman of the Stikeman Oil Company invited Ledbetter to come to his office for conversation with a gasoline supplier. There Ledbetter met J. R. Rickley, a representative of the National Refining Company of Cleveland. ${ }^{133}$ National Refining did not at that time distribute its gasoline in Detroit. Rickley offered Stikeman and Wayne exclusive rights to sell White Rose gasoline in Detroit. ${ }^{134}$ Ledbetter did not act on that offer, and testified that

${ }^{120}$ Record, 983. In explaining his inability to obtain jobber status earlier, Ledbetter testified that "the reason $I$ got on that basis, or the principal reason, I believe, was the fact that I succeeded after two years' effort in selling them on the idea that I could do a better job for less money." Record, 984.

${ }^{130}$ Record, 984.

131 Record, 1147.

${ }^{132}$ He claims he reported the offer because Standard "asked me if I had any such offers within recent times, about that time." Record, 1151. Raupagh confirmed the fact that Ledbetter reported the Aurora offer to him. Record, 2012.

${ }^{133}$ Record, 1153.

${ }^{134}$ According to Ledbetter, "He offered the two companies, Stikeman Oil Company and .Wayne Oil Company, as an inducement for the two of them together to purchase their requirements from the National Refining Company, their house brand gasoline, with the exclusive sales for Detroit, and a guaranteed margin of $1 \frac{1}{2} \phi$ on a $6 \phi$ Detroit market or better; below $6 \&$ we to stand the cut fifty-fifty....

"We were to have the difference between the Detroit market and the Chicago Journal of

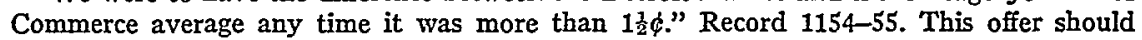
have come as no surprise. For, according to Ledbetter, "Rickley had been talking to us in this same way off and on for probably six months, and this is the first time that a real concrete offer ever came out of it. I had been down to Stikeman's office talking to Rickley probably three or four different times prior to that, and at one of which times he brought 
he did not think that Stikeman had, either. ${ }^{135}$

Stikeman Oil Company. No representative of the Stikeman Company testified, although Raupagh testified with respect to the company. Raupagh had this to say about the Stikeman Company:

Prior to 1936, I don't recall exactly what the exact date was, we lost them to the White Star Refining Company, I think that must have been about 1932 or 1933, and for a short period of time White Star Refining Company, which is now Socony Vacuum Oil Company, supplied them with their requirements of gasoline. Previous to that, Mr. Stikeman told me that they were solicited by the White Star Refining Company, and he was getting a better proposition than we were giving him at that time. Just how much it was, I don't even recall, but it was at least from a half to one cent per gallon better. Then, it was at a later date he had an offer from Phillips 66 . That offer was along the line of a contract offer. That is, they wanted to give him a contract and wanted to tie him up for a certain number of years. Mr. Stikeman and I discussed that at quite some length. It was quite an advantageous offer, advantageous from the standpoint that this margin would have been more than we were allowing him at that time. The next offer that he told me about was in December of 1940 when he received the offer from the National Refining Company, along the same lines, about which I have testified in regard to the Wayne Oil Company. ${ }^{136}$

Further, Raupagh recalled that, at about the same time that the Middleton Oil Company left Standard for Shell, Stikeman also received an offer from Shell. ${ }^{137}$

Standard's four remaining jobbers were not passive agents in the process of price-making at the wholesale level. They had to bargain for what they got, and they bargained hard and well. Their supplier was evidently unwilling to give them better terms than it had to give, and it calculated well just what it would take to keep their business. Studying the bargaining process between the Standard Oil Company and its Detroit jobbers contributes to a better understanding of the role of the jobbers, the character of Standard Oil's gasoline pricing, and of the state of competition among gasoline suppliers generally.

The jobbers had all grown from very small origins and never became business giants. They grew relatively large before obtaining jobber status, and indeed became jobbers in large part because of their volume of business. They were aggressive and, apparently, very competent businessmen.

his-I believe his vice-president from Cleveland-over to see us; probably six months prior to this time." Record, 1166.

Ledbetter interpreted the offer as being made jointly to the Wayne and Stikeman firms. As he explained, "he made a joint offer to us in an endeavor to get sufficient distribution over the City of Detroit to warrant them to come in here and spend the money necessary to put it over, and it would take more than one little outfit like mine to do it. That was the gist of the way I got it." Record, 1213.

${ }^{125}$ Record, 1155.

${ }^{130}$ Record, 2013-14.

${ }^{207}$ Record, 2014. 
Standard of Indiana, the largest gasoline supplier in the Midwest, was neither small nor very aggressive. In fact, there are reasons for believing that Standard was too passive for its own good. It may very well have overestimated its ability to maintain its market position and profits against the incursions of small but more aggressive rivals. Both the record and industry spokesmen indicate that Shell, Gulf, and Socony-Vacuum, among the majors, and the non-majors in general, were more aggressive and alert than the socalled market "leader." It is absolutely clear that, in the case of its pricing negotiations with the jobbers, Standard occupied a defensive position. It was apparently trying to hold its lines at the least cost to itself. It was most assuredly not attacking its rivals either to destroy or discipline them: It reluctantly followed other suppliers in pricing at the jobber level..$^{138}$

A fundamental cause of the success of the jobbers' negotiations was the general state of petroleum and gasoline supplies. Relative to the supplies at hand there was little enough business to go around, and firms were disposed to compete for it. The analysis of the jobbers' negotiations indicates that they did so. Spokesmen of Sun Oil and Sinclair, two major firms that did not employ dual distribution agreed on that. ${ }^{139}$

\footnotetext{
${ }^{133}$ Many say that Standard of Indiana is now both a more alert and aggressive organization, and it may very well be so.
}

${ }^{139}$ As Paul H. Harrison of the Sun Oil Company testified, "Q: Do you think in your judgment, based on your experience, Mr. Harrison, that the elimination of any one of the suppliers that you have named who do business through a jobber would eliminate the competitive difficulties in Detroit? A: I am afraid that it would not. Q: To make that just brutally clear, Mr. Harrison: if the Standard Oil Company were prevented from selling gasoline to the four jobbers involved in this action and everybody else kept on doing business as they have been doing it, as you know they are doing it in Detroit, would it make any difference in the competitive situation in Detroit, in your judgment? $A$ : If any other major company, we will say comparable in public acceptance and ability of the Standard Oil Company, were to take on the business of these people, it would not in any way cure or help to cure this competitive situation. Q: Do you have the slightest doubt in your mind, Mr. Harrison, that if that business were lost to the Standard Oil Company that some other supplier, and a major supplier, would not immediately take it on? A: There is a possibility that they would, because there is a lot of us that are still very foolish. . . . I think if they were not under the same restraint as the Standard Oil Company that they would take it on." Record, 344-45.

James E. Dyer of the Sinclair Oil Company was of the same opinion. When questioned about the ability of Ned's, and other similar firms, to get gasoline at tank-car prices, Dyer said: "I had in mind the intense competition in our industry. There are many engaged in it. It is the business of $-a$ business of intense competitive effort. There is a constant struggle going on to obtain new business and, particularly, business of large volume with accounts that can pay for the merchandise which they get, and what I had in mind in the question put to me was the idea of the availability of this merchandise at these prices, thinking of the condition as I know it every day when people are out struggling to get that very type of business.

"As I say, our company wouldn't take it, because it conflicts with a fundamental policy of our marketing problem, but I realized there are many hungry mouths in the oil industry that would be wide open for, generally speaking, that type of business." Record, 950 . 


\section{The Jobbers as Resellers}

It is probable that if Standard's four favored jobbers had not adversely affected the market position of retailers, their supplier would not have been singled out for attack under the Robinson-Patman Act. ${ }^{140} \mathrm{It}$ is important for this reason, as well as to test the economic theory of price discrimination, that we inquire into the effects of the differential pricing practiced by Standard Oil of Indiana. This section shows what the Standard jobbers did with the price concessions they got.

Ned's Auto Supply Company. Ned's was not only the second largest tankcar customer ${ }^{141}$ Standard had in Detroit; it was also the largest retailer of Standard gasoline. Apparently its formula for success as a retailer called for saving motorists money as well as offering them good service. Ned's was a veteran price-cutter, ${ }^{142}$ and its price cutting took several forms. One of them involved nominally, at least, some classification of customers into a special "commercial" class. ${ }^{143}$

In addition to the "commercial discount," during 1939 Ned's issued to its gasoline customers so-called "trading stamps" that were redeemable in merchandise or, for a time, cash. ${ }^{144}$ The stamps were issued freely; indeed, Ned's

${ }^{140}$ The same logic applies to the other major oil companies against whom similar cases pend. This is not to deny the legal probability that, regardless of how the jobbers resold what they bought under conditions of discrimination, their suppliers would technically have violated the law. It is highly probable, however, that no one would have complained if there had been no price impact on reseller's markets.

${ }^{311}$ Citrin-Kolb was the largest.

${ }^{142}$ According to one line of testimony at one of its stations, at least, Ned's was a pricecutter almost from the beginning. Record, 497, 516.

${ }^{143}$ As Charles H. Gershenson put it, "As long as we have been in business there has been prevalent a so-called commercial discount that operators of commercial vehicles or people operating passenger cars but performing some commercial function like collectors or vendors, candies, and things of that nature, and insurance men have received that the industry has recognized as a commercial discount. That has been in effect from the time we first started in the gasoline business right up to today." Record, 240. Ballinger ordered this statement stricken as an unresponsive answer. Record, 241.

The discounts varied from 1 to 2 cents per gallon off Ned's posted prices, and, in Charles Gershenson's words, were accorded to a loosely defined group of buyers whose "classification has varied from time to time depending upon competitive situation. That I can't state now, general qualification." Record, 242. Ned's gave their attendants loose "instructions" with respect to extending commercial discounts. In Gershenson's words, "If we are satisfied that competitors generally are extending commercial discounts liberally, why, our instructions to our attendants would be to satisfy themselves that that particular customer is either buying at a commercial discount elsewhere or would buy if we didn't extend it to that customer, and then, in that case, to meet the competitive condition, why, we would extend a commercial discount. That is about the extent of the instructions." Record, 244.

${ }^{14}$ Ned's began issuing the stamps about August 25, 1939, when stamps worth 2 cents were given with the purchase of a gallon of gasoline. Sometime early in November the amount was reduced to 1 cent per gallon, and on November 15, 1939, Ned's stopped issuing trading stamps altogether. Record, 246-47. 
advertised them. ${ }^{145}$ In addition to its commercial discounts and the trading stamps, Ned's gave various premiums and free goods to its customers. ${ }^{146}$

The foregoing techniques of attracting trade are in a sense discounts from something, and are therefore meaningful only if the price level from which the discounts are taken is specified. While Ned's was offering discounts, its posted prices were also lower than those of the majority of retailers selling major brand gasolines. Ned's was a price-cutter. ${ }^{147}$

${ }^{15}$ Record, 246-47. Charles Gershenson later testified, however, that he believed that Ned's was issuing trading stamps even before they went on the tank-car basis. Record, 1841.

${ }^{346}$ It was Ned's long-standing practice to give free newspapers to those who visited its stores and service stations. For a time Ned's gave gasoline customers free samples of Pyroil, a nationally advertised gasoline additive, and on certain occasions gave inexpensive premiums. Record, 254-57.

14: Table 4 shows Ned's posted prices as compared with the prevailing retail price in Detroit. These data indicate that, even before the commercial discounts and other price-cutting techniques are considered, Ned's posted prices were lower than most. The data also indicate that, to some extent, the trading stamps were a substitute for cutting the posted price. For example, when trading stamps were discontinued in November, 1939, Ned's cut its posted prices. Some customers-perhaps many-qualified for commercial discounts ranging up to 2 cents per gallon. According to Gershenson's testimony, the number of commercial discount customers and the amount of the discount depended upon "competitive conditions." We should therefore expect that variations in the number of such "commercial customers," and in the amount of the discount-neither of which data appear in Table 4, are in themselves important competitive devices. Since we do not have those data, we cannot assess the full amount of Ned's price cutting. This may, although it need not, explain one rather curious thing about Ned's prices. Ned's first went on the tank-car basis on March 7, 1938. Whereas testimony indicates that it was a price-cutter long before that, Ned's did not reduce its posted price immediately after receiving full jobber status. Unfortunately, the data do not indicate whether there were changes in Ned's pricing practices just after it received the original $\frac{1}{2}$ cent per gallon reduction from Standard. It is possible, of course, that it might have reduced its effective prices simply by relaxing its qualifications for "commercial consumers."

In any case, Ned's almost continuously posted prices lower than those posted by the majority of filling stations in Detroit. Ned's, however, was undersold by the so-called nonbrand or "Gyp station" operators in amounts ranging up to $7 \frac{1}{2}$ cents a gallon. Record, 1858. See also Record, 1814, 1846, 1847, 1851, 1856.

By way of summary, Gershenson had this to say: "We will make a survey following receiving certain information as to what our competitors are doing, sometimes through signs, although there haven't been many signs in the last year and a half or so, and when the competitive situation is such that we know we are losing volume to our competitors, why, we will meet their prices whenever possible. We have never been able to do that, as far as Joy, Zip, Speedway, Fleet-Wing, and oh, a number of outlets all around us that you haven't asked me about." Record, 1855.

By November 29, 1939, the Retailer's Association had apparently harassed Ned's considerably. Ned's may have anticipated legal action, and decided to moderate its price policy. On the other hand, Ned's may simply have chosen to give "under the canopy" discounts from relatively higher posted prices. While its significance is far from clear, it is also interesting that Ned's posted prices sometimes did not immediately follow changes in the prices it paid Standard for gasoline, although in general they did bear a close relationship to one another. On several occasions-as in January 1938, August 1938, January 1939, April 1939, and November 15, 1939-Ned's did not lower its posted price when the tank-car price fell. On other occasions, it lowered its posted prices although the tank-car price remained un- 
Whereas Ned's was a price-cutter, its prices were not as low as some. And it was not only non-brand stations that undersold Ned's. Some major brand distributors were also able to undercut Ned's low prices, at least on occasion. ${ }^{148}$

One technical obstacle to determining whether Ned's was really a pricecutter remains. That it posted prices lower than the prevailing posted price is certain. But that it actually sold for less than the effective prevailing price is something else again. In short, prices posted by Ned's do not show a complete picture of the prices Ned's charged. By the same token, there is considerable evidence that, during the period under consideration, all posted retail prices should be suspect; "under-canopy" discounting was common. And, if the other stations discounted their posted prices by even as little as the same amount that Ned's actual prices undercut their posted prices, the effective or real price would be no lower at Ned's than elsewhere. The data of Table 4 overstate Ned's prices, because of Ned's commercial discounts, etc. On the other hand the fact that the "prevailing price" is derived from posted prices that may not actually be charged tends to exaggerate the extent of Ned's price cutting. The best evidence of Ned's role as a price-cutter is therefore not absolutely conclusive. Yet it is reasonably clear that Ned's was a price-cutter. Ned's general reputation in the trade is an indication of that. An even better one is the fact that it was able very quickly to increase its business significantly. ${ }^{149}$

changed (as in July 1938, September 1938 , November 1938, and November 10, 1939). On one occasion, April 1938, Ned's posted price did not, at least immediately, respond to a strictly higher tank-car price. In June 1938, Ned's raised its posted prices very slightly, even though the tank-car price remained the same.

${ }^{148}$ For example, in September 1939, a Stark Hickey Shell station undersold a Ned's station by 1.4 cents, as did the adjoining Socony station. Record, 1851. A Sinclair station, which Gershenson characterized as "the thorn in our side," undersold Ned's 2 cents a gallon as late as 1941. Record, 1851-52. Another Sinclair outlet in November 1939 undersold Ned's 1.7 cents per gallon. Record, 1851. One Texas Company station in March 1940 also sold at 2 cents per gallon off Ned's price; another undersold Ned's 2.6 cents per gallon on November 17, 1939. Record, 1853-54, 1856. In May 1940, a Gulf station undersold Ned's 2 cents per gallon. Record, 1857.

${ }^{110}$ Table 6 shows the volume of Standard Red Crown gasoline sold by Ned's. It is clear that some part of the increase in Ned's business between 1936 and 1938 was diverted from its rivals, since for part of that period aggregate Detroit gasoline consumption declined. Furthermore there is a great deal of testimony to the effect that Ned's got business from other retailers. An example is the testimony of Douglas Leake, lessee of a Standard Oil Station. Leake's station was about $\frac{1}{4}$ mile from the nearest Ned's outlet. Even so, when Ned's began underselling him 2 cents a gallon late in 1934 and early in 1938, he reduced his prices. As Leake saw it, "the drop in business practically compelled us to become more competitive in order to do business." Record, 408. It is of course possible that much of Leake's losses of business may be attributed to the decline in aggregate gasoline purchases in Detroit. However, other operators testified that they lost specific customers to Ned's. Record, 434-35, 576-79.

Thus it is that Ned's cut its prices, got business from its rivals, and prospered in the 
The Citrin-Kolb Company. Citrin-Kolb was Standard's largest tank-car customer in Detroit. It engaged in both wholesale and retail activities, although it was primarily a wholesaler. Citrin-Kolb was a price-cutter at both levels. Table 6 indicates the prices charged for Red Crown gasoline at the retail stations Citrin-Kolb operated from January 1, 1937 to February 27, 1941. Several facts are evident from that table. (1) To some extent CitrinKolb charged different prices at its stations, ${ }^{150}$ although generally these differences were slight or did not persist. (2) Citrin-Kolb's prices in general varied with the price pattern for the City of Detroit.151 (3) Especially during 1937 and 1938 Citrin-Kolb was cutting prices about as severely as was Ned's Auto Supply Company. ${ }^{152}$

In addition to cutting prices at the retail level, Citrin-Kolb undercut selectively at wholesale. Citrin-Kolb made direct or indirect concessions to three different retail dealers operating a total of seven stations. The largest of these dealers was Langer and Cohen, which in 1936 operated five retail stations and did a volume of about a million gallons per year. In that year, Citrin-Kolb began to sell to Langer and Cohen at a price one cent per gallon lower than the Standard tank-wagon price. ${ }^{153}$ There is little doubt that the fundamental basis for Citrin-Kolb discount to Langer and Cohen was Langer and Cohen's volume. ${ }^{154}$

process. It engendered very bad will against itself, and against its gasoline supplier as well. A whole procession of Commission witnesses testified bitterly that Ned's was the cause of Detroit's price war, and in so doing exhibited their strong dislike for Ned's and Standard Oil. Rightly or wrongly, Ned's had become the symbol of the market's relentless pressure upon prices. An example is the way William Ecker, a Sun Oil salesman and a former filling station operator, replied to questioning: 'Q: You don't like Ned's do you? A: As a dealer, I cussed them, and every God damn thing else. ... Q: And you don't like the Standard Oil Company because the Standard Oil Company sells Ned's gasoline; is that true? A: No, the Standard Oil Company does things underhanded, just like Ned's does." Record, 373.

${ }^{250}$ For example compare the prices charged at its Joseph Camp station with those in effect at the Woodward \& Westminster station.

${ }^{151}$ It is not too difficult to detect the periods of greatest general price cutting from these specific data. Citrin-Kolb's most persistent and deepest cuts below the prevailing price level occurred during 1937 and early 1938, whereas the prevailing price itself declined most sharply during 1938 and November 1939. An exception is the 2.15 cent cut in effect for a short time in October 1939, at the Woodward \& Westminster station.

${ }^{152}$ During 1938 or 1939 , for two to three weeks, Citrin-Kolb also issued to "almost everyone" 2 cent-per-gallon discount cards. Record, 275-78.

${ }^{100}$ Record, 882. It is significant that the invoice price to Langer and Cohen was the same as that to the other Citrin-Kolb customers. Citrin-Kolb accomplished the concession by rebating 1 cent per gallon.

${ }^{154}$ According to Citrin-Kolb's General Manager, that "preference was based on volume." Record, 882. Not inconsistent with that statement of the importance of volume is the testimony that followed immediately: "The real reason for giving them this treatment in the beginning was to meet the competition of other offers which they had." Record, 883. The attorney for Standard offered to prove in further detail the character of the competitive 
Whereas Citrin-Kolb lowered prices to Langer and Cohen because of volume or competitive offers, the case of Sid's Super Service was different. ${ }^{165}$ Citrin-Kolb leased that station and subleased it to Sid's Super Service. Sid's paid Citrin-Kolb $\$ 235$ monthly rent. During the price war of August through October, 1939, Sid's was in danger of collapse. To assure the flow of its gasoline by protecting its distribution system was Citrin-Kolb's object in this case. ${ }^{158}$

The third favored dealer was Ferguson and Coury, which operated a service station in connection with a motor boat works. ${ }^{157}$ From the beginning, CitrinKolb sold them gasoline for one-half cent per gallon less than the tank-wagon price. Although Trial Examiner Ballinger did not permit full testimony on the subject, it appears that in 1936 both the Gulf Oil Company and CitrinKolb were negotiating for the Ferguson and Coury contract, and that CitrinKolb gave the price reduction to meet Gulf's offer. ${ }^{158}$ By doing so, CitrinKolb got the contract.

Evidently Citrin-Kolb's pricing techniques were successful, at least in 1936-37, when it was cutting prices most vigorously at retail. As Table 7 shows, its gallonage climbed from a little over two million gallons in 1936 to

offers made to Langer and Cohen. Trial Examiner Ballinger rejected the proffer. This is part of what Standard offered to prove: "That Langer and Cohen, in consideration of receiving said discount from Citrin-Kolb Oil Company agreed to take deliveries in minimum of 1500 gallons at a delivery.

"That Langer and Cohen, in addition to receiving deliveries of gasoline from Citrin-Kolb Oil Company, purchased from other suppliers, among which were Victor Oil Company, Fleet Wing Gasoline, and Plymouth Oil Company Dixie Gasoline, and that on January 25, 1940, Victor Oil Company sold 1500 gallons of Fleet Wing gasoline to Langer and Cohen, of which 744 gallons of $74-76$ Octane Gasoline was sold at $10.75 \phi$ per gallon, and 850 gallons of Ethyl gasoline was sold at $12 \&$ per gallon, both of which prices included state and federal taxes, which prices represented a discount in excess of 16 per gallon from the regular dealers tank wagon price at said time. Also on November 25, 1940, Plymouth Oil Company sold to Langer and Cohen 790 gallons of Dixie gasoline at a price of $11.25 \%$ per gallon which was a discount in excess of $1 \&$ per gallon from the dealer tank wagon price in effect at that time. And that by reason of such competitive situation it was necessary for Citrin-Kolb Oil Company, in order to retain Langer and Cohen's patronage, to sell to them at their various stations gasoline at a discount of 1 cent below the regular dealer tank wagon price prevailing at the time of sale." Record, 898-99.

${ }^{105}$ Sid's Super Service was located at Chicago and Dexter in Detroit. Record, 290, 881.

${ }^{250}$ As Citrin-Kolb's general manager explained, "It was . . . during a period when a Cities Service station directly across the street had instigated a gas war in the neighborhood.... Well, the operator, in order to maintain his business, had to meet competition of the station across the street, and he came into the office and told us he would not be able to operatenot be able to pay his rent, or not be able to exist in business if he had to continue the same overhead and sell at the cut-rate prices. So in order to keep him in business, we waived that rental for the period of three months." Record, 881-82. Citrin-Kolb waived the rent for August, September, and October. The Cities Service station was underselling Sid's by 2 cents per gallon; in addition a Zip station one block away was selling gasoline for about $5 \frac{1}{2}$ cents less than the prevailing price. Record, 882 .

${ }^{157}$ Record, 893. 
slightly more than five and one-half million gallons in 1937. By 1940 gallonage had fallen and was somewhat below the 1937 level. Apparently retail price cutting was an important element in Citrin-Kolb's growth: growth stopped when its prices became more conservative. ${ }^{159}$

The Wayne Oil Company. The retail aspect of Wayne's gasoline business may be treated briefly. The Wayne Oil Company operated no retail stations until September 8,1939 . The prices it charged at the stations it operated are shown in Table 8, as are the prevailing retail prices in Detroit during the same periods. Four obvious conclusions can be derived from these data. First, during the most severe Detroit price wars ${ }^{160}$ Wayne did not operate retail stations at all. Second, Wayne sometimes charged slightly different prices at its different stations, especially during the early part of the series shown in Table 8. Third, after about November 18, 1939, Wayne stations' departures from the prevailing price were negligible, and for the most part they seem to have sold at the prevailing price. Fourth, contrary to Trial Examiner Ballinger's flat statements in his report, Wayne stations did sell at prices significantly below the prevailing price during September, October, and part of November 1939. We may say; however, that the Wayne Company was not so persistently a price-cutter as Ned's.

Because it came into direct retailing rather late, and because of the relatively small amount of retail business it did-see Table 1-it will be more profitable to investigate Wayne's role as a wholesaler. ${ }^{161}$ If we can accept Ledbetter's testimony, Wayne was even less a price-cutter at wholesale than at retail. ${ }^{162}$ Furthermore, for some reason the retail stations supplied by Wayne altered their posted prices closely together and also tended to lag somewhat behind the price movements of the more aggressive marketers. ${ }^{163}$

${ }^{150} \mathrm{Jacob}$ Citrin testified that after 1935 Citrin-Kolb greatly expanded its operations. It did so in several ways. As he put it, "We have acquired more property, built more stations, and we have also acquired more dealers." Record, 1316. None of the dealers it so acquired had previously been customers of the Standard Oil Company. It is not clear how CitrinKolb secured their custom.

${ }^{160}$ An exception is the very sharp, but brief, war of late 1939.

${ }^{101}$ According to the testimony of its chief officer, Mr. Ledbetter, the only "reason the Wayne Oil Company ever operated a retail outlet since it became a wholesaler was what I would term an emergency reason." Record, 398.

- ${ }^{102}$ As he put it, "Wayne Oil's prices to its dealers have always been exactly the same as Standard Oil prices to its dealers." Record, 386.

${ }^{103}$ See Ledbetter's testimony Record, 392. It is corroborated by the testimony of Cash Hawley, operator of a station supplied by Wayne. Record, $430 \mathrm{ff}$. One insight into the pricing of Wayne's customers is given by the testimony of John $J$. Wotring, a Wayne dealer. Although he later softened the effect of his first answer, it nevertheless seems significant. As the questioning developed: "A: We have always retailed our gasoline at the set retail price. We have never-in other words, we never have discounted it. Our price is given to us by the Wayne Oil Company. Q: Does the Wayne Oil Company tell you what the prevailing price is? A: The Wayne Oil Company even paints the signs." Record, 577. 
If we accept completely the testimony that Wayne passively accepted both the Standard Oil tank-wagon price and the prevailing retail price, we must recognize one rather troublesome fact. As Table 9 indicates, Wayne managed to increase its gallonage continously and significantly from 1936 through 1940. In fact, it even increased its 1938 gallonage more than eight per cent over the 1937 figure. This was a period of declining prices, and, for Detroit, declining gasoline consumption as well. It is unlikely that a seller who does no better than simply meet the prevailing price-while others sell significantly below it-will be able to increase his business appreciably. One explanation is that Wayne made so-called "advertising" allowances to its dealers. ${ }^{164}$ Another lies in so-called "rent adjustments" or "allowances" made during the price wars. ${ }^{105} \mathrm{Mr}$. Ledbetter testified that Wayne required evidence that these allowances were in fact being used for advertising of the sort Wayne wanted. It is possible that some of these allowances were really price concessions. Whether they were price concessions or a subsidy for Wayne dealers' advertising, such expenditures furnish at least a partial explanation of how Wayne increased its business and at the same time charged the prevailing price. ${ }^{106}$

Stikeman. There is very little evidence indicating how Stikeman sold its gasoline. What evidence there is shows a passive adaptation to prevailing prices. There is nothing to indicate that it sold at wholesale for prices lower than Standard's tank-wagon. Table 10 shows that for the time it operated service stations its retail prices were precisely equal to prevailing prices. Such conservatism may explain the very sizable and continuous gallonage losses Stikeman suffered between 1937 and 1940 as shown in Table 11.

What Ned's or any other individual jobber did was not the cause of the rather continuous price cutting that took place in Detroit in the 1930's. It was the persistent oversupply of petroleum and its products, together with the relative rigidity of the retail gasoline price that made an ultimate collapse of the price level inevitable. The growth of non-brand gasoline distributors placed a severe strain upon the major companies, and involved them in increasing rivalry among themselves. A most important competitive technique was price discrimination at wholesale and retail levels, and it was used by the non-brand suppliers and distributors as well as by the majors. Ned's and other important jobbers not supplied by Standard Oil were denounced as price leaders. If they were price leaders at all, they were "barometric" price

Tes Record, 3128 ff.

${ }^{165}$ Record, $1175-76$.

${ }^{200}$ Unfortunately the Record is inconclusive on these points. The reason is that Standard made alleged "reciprocal benefits" from jobber advertising a part of its cost defense. The Commission's attorney, apparently desiring to prevent the use of such testimony as a cost defense, was successful in having it excluded. He apparently overlooked the possibility that "advertising allowances" may actually be indirect price concessions. In any case, legal strategy prevented full testimony on the subject. Record, 3133-34. 
leaders, ${ }^{167}$ and then only with respect to the retail price of major gasolines. Barometric leadership would be consistent with the thesis that the fundamental causes of price cutting at retail were the vastly more significant factors of crude oil and gasoline supply, and the growth of non-brand distributors. But whether Ned's and other distributors like it were the primary cause of Detroit's price wars, it is clear that, taken together, they were an important factor in the business, and contributed to the downward pressure on retail prices.

\section{The Role of Three Small Firms: Argo, Aurora, and the REd Indian OnL CoMpanIes}

In part because of the unwarranted inferences drawn about them, in part because of the erroneous "facts" stated with respect to them, ${ }^{168}$ and in part because they illustrate well certain principles of the theory developed earlier in this article, it will be useful to inquire into the role played by three somewhat minor companies in the Detroit area.

The Argo Oil Corporation. Argo was incorporated in 1922, and did from time to time varying types of business. ${ }^{169}$ Argo's gallonage in 1939 was 4,219,577, and 1,930,901 in 1940. However, Argo's Vice-President, Mr. Feinberg, estimated that Argo's gallonage for 1939 was about 4 million, and about 7.5 million for $1940 .{ }^{170}$

Feinberg testified that "most" of Argo's gasoline came from the Ohio Oil Company of Findlay, Ohio, and "some" of it was sold as Marathon brand

\footnotetext{
${ }^{107}$ George J. Stigler, who coined the term, contends that the "barometric" price leader "commands adherence of rivals to his price because, and to the extent that, his price reflects market conditions with tolerable promptness." (Italics supplied.) Stigler, The Kinky Oligopoly Demand Curve and Rigid Prices, 55 J. of Pol. Econ. 432 (1947). The barometric firm simply recognizes the true market conditions and formalizes them.

The following testimony of Chester Martoglio indicates, though it does not prove, that Ned's was the major gasoline price leader in one locality: "Q: You just mentioned a Standard Oil station that you said you watched. Which one was that? A: Marvin Goldberg's. Q: And after Ned's station opened up, did Goldberg's and Ned's sell at about the same price, or do you know? A: Well, the way I figured it, Marvin watched Ned's, and I watched Marvin's." Record, 426.

${ }^{168}$ See, for example, Wallace and Douglas, Antitrust Policies and The New Attack on the Federal Trade Commission, 19 U. of Chi. L. Rev. 684 (1952).

${ }^{100}$ Record, 3016. According to Charles Evan Feinberg, Argo's Vice-President, "we have been tank car operators, gasoline distributors, fuel oil distributors." Record, 3016. It also sold at retail after about 1930. Resp. Exh. No. 55A, Record, 4875, shows Argo's reported gasoline gallonage for 1936-40.

${ }^{170}$ Record, 3016. There is no clear explanation for so great a discrepancy for 1940 except the possibility that either Feinberg's testimony or Resp. Exh. No. 55A, Record, 4875, contains a gross error. It seems extraordinary that Feinberg, long a gasoline marketer, and VicePresident of Argo, should make such a large error in estimating a total only a little more than one year old. Feinberg testified on February 20, 1942, and 1940 figures would have been available in early 1941 .
} 
gasoline. "Most" of it, however, was sold unbranded. ${ }^{171}$ After March 1941, when its contract terminated, Argo bought no more gasoline from the Ohio Oil Company. After their contract with the Ohio Company terminated, Argo shifted almost entirely out of the gasoline business and into the sale of fuel oil. ${ }^{172}$ Argo had a bulk plant, and sometimes received gasoline shipments there. ${ }^{173}$

In addition to operating three retail stations during 1939 and 1940, Argo sold Marathon gasoline in tank-wagon quantities"174 to "not more than two or three" other small tank-wagon customers. To them, Argo's prices were lower than the posted major tank-wagon price. ${ }^{175}$ On the matter of prices, however, Feinberg was vague, either through choice or because he could not rely upon

${ }^{171}$ Record, 3017. The Marathon brand name was the property of the Ohio Oil Company. The testimony on this point is as follows: "Q: It made no difference to you who manufactured the gasoline. A: None. Q: Now as a matter of fact you got your supply of gasoline during the years 1939 and 1940 from other sources than the Ohio Oil Company, didn't you? A: We did, some." Record, 3050.

Trial Examiner Ballinger did not permit Feinberg to answer questions divulging other sources of Argo's gasoline. Record, 3051. In that connection Mr. Abbott, an attorney for Standard Oil, offered to prove that "in 1939 the Argo Oil Company agreed to furnish the Titan Refining Company 4,000 barrels of crude oil daily for refining purposes, and that the contract further provided that in this deal the Argo Oil Company would have a further source of supply of gasoline which would enable it to fulfill its contract on engagements with persons with whom it had agreed to furnish gasoline, and the purpose of it is to show that they really did have in contemplation avenues and sources of supply other than the Ohio Oil Company." Ballinger rejected this proffer of proof. Record, 3053-54.

As Feinberg declared in further testimony: "Q: Where is the Marathon brand of gasoline or where was it manufactured in 1939, if you know? A: I do know. Q: Was it in Findlay, Ohio? A: The brand itself was manufactured in Findlay, but a lot of the gasoline supplied to us by the Ohio Oil Company was never manufactured in Findlay. Q: Was it traded with other companies? A: Yes, sir. Q: Didn't it make any difference to you where it came from? A: No, sir. Q: Then was it Marathon gasoline? A: We called it Marathon." Record, 3055-56.

${ }_{172}$ Marathon gasoline was then no longer sold in Detroit. Record, 3018. Argo could, of course, have bought gasoline from some other source. The following testimony is therefore somewhat unclear. "A: With the cancellation of the contract, we had no alternative but to practically discontinue the business. Q: Well, I won't pursue that, Mr. Feinberg. I just thought the fact that you ceased to buy from Ohio wouldn't necessarily preclude the company from continuing? A: No, it didn't." Record, 3018.

${ }^{173}$ Under the Ohio Oil arrangement, Argo could, at its option, take delivery at either its own bulk plant or order delivery to its customers. The price was the same in both cases, and the Ohio Oil Company absorbed transport costs. In some cases the Ohio Oil Company traded gasoline with other companies, and transported it from their installations to Argo. In other cases it transported its gasoline directly from its marine terminal on the River Rouge. Record, 3018-19. Argo's contract with the Ohio company gave Ohio the right to limit the volume of Argo's purchases. Apparently the Ohio Oil Company had exercised this right at least once, although it is not established how often it did so. Record, 3020-21. According to Feinberg, "We are permitted a leeway of ten per cent more or less of the figures as stated in the schedule." Record, 3025. "There have been occasions when we would require more gasoline and were not able to get it from the Ohio Oil Corporation. There have been others when we were; in excess of the amount mentioned." Record, 3026.

${ }^{174}$ Feinberg specified that these were customers buying in quantities of 1,500 gallons or less. Record, 3026-27.

${ }^{275}$ Record, 3026-27. 
his memory. ${ }^{176}$ Two inferences may be drawn from that testimony. First, Argo's prices were different for large and small buyers. Second, it is very likely that prices varied even among the smaller purchasers. It is clear that Argo priced flexibly, and, over short periods at least, charged different buyers different prices. ${ }^{177}$ Not only were Argo's prices flexible, and perhaps discriminatory as well; but the prices they paid the Ohio Oil Company were also flexible. ${ }^{178}$ Argo, like the major oil companies, made price concessions to

${ }^{176}$ This part of his testimony is an example: "A: Tank wagon price was possibly, in one or two cases, a half a cent less to the smaller service station than the posted tank wagon price at that time. Q: Whose posted tank wagon price? A: I would probably say Standard Oil Company's posted tank wagon price. Q: Are you referring to the prevailing major tank wagon price? A: That's right, if you are talking about small retail establishments taking 1500 gallons." Record, 3027-28.

${ }^{177}$ As Feinberg testified: "A: The prices varied. I would say prices ranged anywhere from- Q: Well, just a minute. I would rather have you state- A: Exactly? Q: - specific prices and the number of customers and the period at which you sold at a certain price. A: Well, that is rather difficult to give you, sir. I would have to break down all the books. We had no stated definite price. Q: Well, what I mean is, did you, say, in January, 1939you sold so many customers at one price or so many at another. If you can't give us the number of customers, can you at least give us the prices? A: The prices would vary anywhere from 6.3 to 6.6 per gallon. Q: During what period? A: Periods in '39. I can give you the exact dates of different shipments sold to-Q: Will you do that? A: To different dealers, yes. All I got to do is give you the invoices, but there was no fixed price, unfortunately. This one here, for instance, is the 16th of August of '39, .067. This one is 29th of August, .066 to another customer. Here is one for .063 to another customer. Q: Did you sell to any customer below $6.3 \&$ per gallon? A: I think 6.3 would be about the lowest price at that time." (Italics supplied.) Record, 3039. But Feinberg did not prepare a schedule of all invoices and sales showing dates and prices. He simply read out a few chosen from among many. In his words, "we just picked out invoices at random over those periods." Record, 3041 .

Although it does not conclusively prove anything, it is significant that $\mathrm{Mr}$. Raupagh testified that Argo's pricing policy was one of expediency: "Q: Are you familiar with the tank wagon price of the Argo Oil Company? A: Well, when you say familiar- Q: Can you tell me now whether it is as high or higher than the Standard Oil Company posted price on Red Crown? A: I don't believe I can tell you for the past ten years whether it was as high or as low, because $I$ think they are all over the map. Q: Do they have a posted tank wagon price for Marathon gasoline. [?] A: I believe they have a posted price, but I question whether they follow it. Q: You mean you question whether they follow it in their sales to retail service stations? A: Yes, I do." Record, 2118.

${ }^{178}$ In reciting some of the prices Argo paid during the first six months of 1939 and the first six months of 1940 , Feinberg incidentally divulged the variable character of the Ohio Oil Company's prices: "Q: Did you pay that same price during all of 1940? A: It would vary as conditions varied in 1940. Let me look over the first six months and I can tell you that. Q: Yes. A: For the first six months of 1940 the price prevailed. I don't know about the last six months. ... Q: Will you . . . state whether the contract fixed a definite price to be paid at any time by the Argo Oil Company? A: It fixes a price with variations depending on other market factors. Q: Is your answer that there is no definite price fixed in the contract? A: There is a margin of $13 \dot{4} \phi . \mathrm{Q}$ : Is that a minimum margin? A: Based on various factors which fluctuate, so that our average margin would be about two cents. Q: Was your average margin in fact two cents per gallon under the prevailing tank wagon price? A: Not exactly. There were times it varied from 13 to 1.90 , two cents. It wouldn't exactly be two cents, but it averages about two cents per gallon." (Italics supplied.) Record, 3038-39. 
those who bought in larger quantities. Like Standard, Argo sold large truck transport quantities for one and one-half cents less per gallon than for tankwagon deliveries of less than 1500 gallons. ${ }^{179}$ Since there is no information on Argo's costs, we cannot say whether that differential is discriminatory. It would, however, not be surprising if it were.

Apparently there was no great mystery about whom Argo supplied. For $\mathrm{Mr}$. Abbott, attorney for Standard, was able to name several important customers served by Argo in 1939 and 1940. Not only were these customers important to Argo; they were also well-known factors in the Detroit gasoline market. Among them were Montgomery Ward \& Company, J. J. Bright \& Son, Bull Dog Oil Company, Meurer Brothers, and the Miller Tank Car Company. ${ }^{180}$

The Aurora Gasoline Company. Aurora was, and is, a large but nonmajor seller of unbranded gasoline in Detroit. In 1942, Aurora got its gasoline from two refineries and one cracking plant. ${ }^{181}$ Aurora did no consumer advertising, and sold only unbranded gasoline. ${ }^{182}$ To a much greater extent than the majors, Aurora depended upon buyers who got part of their gasoline from other suppliers. ${ }^{183}$ In common with the flexibility of its other marketing practices, Aurora required little of its buyers. It did not, apparently, suggest or specify resale prices to its customers. ${ }^{184}$ Aurora maintained a sales staff, and gave them some discretion in their negotiations to secure custom. Normally

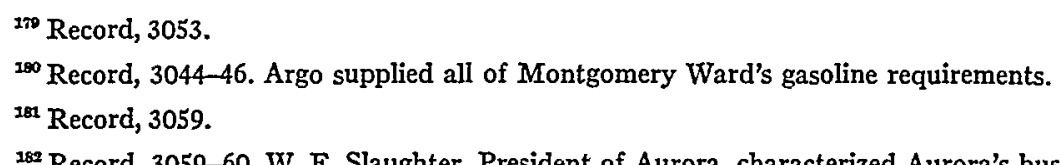

${ }^{182}$ Record, 3059-60. W. E. Slaughter, President of Aurora, characterized Aurora's business in the following way: "We sell the independent gasoline job trade and independent gasoline retailing trade, all of whom, upon buying our gasoline, adopt their own trade name for their own group of stations or accounts and resell under their own names. Other than that, we bid on City of Detroit business and various road commissions. . . . Our business is limited to full tank transport and tank car business and our smallest unit, company-owned unit is around 3200 gallons or over and the smallest unit which we can hire from any public carriers is around 4500 gallons. From there, those sizes range up to 10,000 gallons. We usually specify that it has to be a full load for us to deliver. We don't deliver the so-called tank wagon group; that is the small station-to-station partial load business."' (Italics supplied.) Record, 3060-61. It is not clear how important these reservations really were. Aurora did, of course, sell to retailers. Record, 3084 .

${ }^{100}$ According to Slaughter, "I would say roughly 50 per cent of the accounts shown on this sheet bought from us every month consistently. The other 50 per cent were more or less spot market purchasers, that when our proposition was as good or better than the next man's or they desired our particular quality and service, we were favored with the business and during the other times, the other months when they didn't purchase from us, they bought from competitive sources. .. . To the best of my knowledge, there is one customer on this list that purchased his entire requirements from us. That covers a range of 16 accounts." Record, 3066.

${ }^{284}$ In Slaughter's words: "A: We have no interest whatsoever in what the consumer does with the gasoline after we have sold it to him. Q: If he wants to, he can dump it down the sewer, as far as you are concerned? A: Absolutely." Record, 3084. 
Aurora would not agree to maintain prices for longer than thirty days. ${ }^{185}$ Since Aurora absorbed freight to meet competition, it is probably a safe guess that they would also cut prices selectively to meet local competitive situations. That is consistent with the other observations made with respect to Aurora's pricing techniques, and surely consistent with economic logic. ${ }^{186}$

The Red Indian Oil Company. The Red Indian Oil Company was incorporated in 1923 under the laws of Michigan, and did business in and around Detroit. Before 1934 or 1935 Red Indian sold gasoline produced by the Phillips Petroleum Company. About 1934 or 1935 Red Indian began buying its gasoline from the Fleet Wing Corporation, a subsidiary of the Standard Oil Company of Ohio. The gasoline was sold under the Fleet Wing brand,

${ }^{3185}$ As Slaughter put it, "Usually a quotation from us will be good on a spot basis subject to change without notice but if the account desires to contract on a 30-day basis, or shorter time, we are willing to reach an agreed upon price for that time and will supply and protect that price for that agreed time." (Italics supplied.) Record, 3060 .

Apparently Aurora's prices were fixed by negotiation, for, according to Slaughter: "Well, the salesmen [sic] on our type of business has a price for his product which is more or less agreed upon daily, in the morning. . . . Well, it is agreed upon daily to the extent that competitive conditions might change that price in any given day or even during the day. The salesmen can state a price at which the company is generally offering its gasoline as of that time on the spot market basis, and if he can develop any deal or any proposition from a customer involving any . . . substantial quantity. . . . Well, I would say a substantial quantity might be 50,000 gallons or over. . . . [f]or immediate shipment. . . [T] [Te quantity, of course, would be subject to a definite understanding reached that day depending on our supply of gasoline available for sale that day. Any proposition the salesman can develop that is tangible in any quantity such as I mentioned, say over 50,000 gallons, or over a period of time up to thirty days is reported back to the office and confirmation is obtained from the sales manager and, if acceptable to us on price, the quantity, and the period as suggested, then we confirm the same. ... Any new account that the salesman develops to the point where he believes that it is a tangible account and there is a possibility of closing a deal, he reports that to my particular attention and we draw our credit report and the salesman is held in status until the credit is approved on that particular account." (Italics supplied.) Record, 3061-62.

That Aurora charged different prices according to varying competitive conditions was indicated when Slaughter gave the following testimony: " $Q$ : The delivered price, as I understand it from your testimony, would depend on whether it was delivered east or west of Woodward Avenue, is that correct? A: And also competitive factors, other than the price charged by these hauling companies. Q: In other words, if there was a competitive situation which requires you to sell for less, would your price be less? A: Yes, and I will explain that in this respect: A refinery operating in the northern part of the state, or central part of the state, can deliver from their refinery to Detroit without charging an extra five points [.05 cent] for the east side of town, because their hauling, coming from up north, consists of several hundred miles, approximately, or 150 miles, and the difference coming into town from up north creates no hardship on them to deliver either east or west, whereas we have a condition that occasionally we have to absorb the differential charged by the hauling company, because of competitive conditions and prices quoted by competition from up north." (Italics supplied.) Record, 3082.

${ }^{188}$ An example is the following testimony: "Q: And does your price to the customers in the City of Detroit on regular gasoline at the same time vary as between customers having bulk plant facilities and those who do not? A: We don't make any differentiation because of that reason. Our prices are set by competition; supply and demand." (Italics supplied.) Record, 3085. 
and usually was delivered to Red Indian from a Detroit terminal. ${ }^{187}$ Red Indian was a jobber although, unlike most others, it did not operate retail filling stations. In 1938, it supplied about twenty-eight or thirty retailer customers, and about seventeen or eighteen in 1940. In addition it had two "jobbers": the Victor Oil Company, to which Red Indian delivered gasoline, and the Bath City Service of Mount Clemens, which picked up its own gasoline from Fleet Wing's Detroit or Toledo storage. ${ }^{188}$ Both the Victor Oil Company and Bath City Service operated filling stations of their own.

Apparently Red Indian was able to play an active role in influencing the price it paid Fleet Wing for its gasoline. ${ }^{189}$ From 1939 through 1941 the price Red Indian paid Fleet Wing for gasoline fluctuated at a level from one and five-eighths to two cents per gallon below the prevailing major tank-wagon price. It was normally about two cents per gallon lower than the prevailing tank-wagon price. ${ }^{\mathbf{1 9 0}}$

That Red Indian priced its gasoline in a very flexible fashion is indicated both by quotations from a leading trade paper and by the record itself. In commenting upon the undesirability and unworkability of the Michigan Fair Trade law, I. B. Dworman, President of Red Indian, emphasized its restrictions upon sellers' abilities to reach different bargains with different buyers. According to the National Petroleum News, "The law prevents jobbers from having more than one kind of deal, Dworman related. 'Frankly where is there a jobber with only one kind of deal' he asked."191 From that statement it seems safe to infer, first that differential pricing is pervasive, and second, that Red Indian engaged in it to its advantage. There are other indications that Red Indian sold its gasoline at different prices to different customers. Dworman's testimony on this point is clear:

Q: Now turning to the prices at which you sell, at which the Red Indian Oil Company sells gasoline to retail service stations in the City of Detroit. At any one time do your prices vary to different customers?

$A$ : They do.

${ }^{187}$ In the words of Red Indian's President, Irving W. Dworman: "Generally most all of it comes from a terminal in Detroit. However, on occasions, when they, for reasons best known to themselves, they may ship us gasoline from their Toledo refinery." Record, 3093.

${ }^{188}$ Record, 3094, 3109. Red Indian did have its own bulk storage facilities in Detroit. Record, 3093-94.

${ }^{180}$ As the testimony of Irving B. Dworman, President of Red Indian, reveals: "Q: How is the price fixed at which you purchase gasoline from the Fleet Wing Corporation? A: Generally by mutual understanding between a representative of the Fleet Wing Corporation; namely, Mr. Laufman, and myself. ... I can only answer by saying that it is a matter of negotiation and while the discussion of margin or, rather, the marginal discussion enters into the discussion, definitely does, yet our cost is based upon so much per gallon rather than so much below the tank wagon price." Record, 3098-99.

${ }^{100}$ Record, 3099.

- ${ }^{101}$ Nat'I Petroleum News, p. 16 (Sept. 29, 1937). 
$Q$ : And what are the causes of such variation as exists?

$A$ : There are a group of circumstances that enter into it. Of course it is a matter of determining whether or not we want the business, the amount of money that's generally required to invest in the dealer's place of business; his volume of business; his credit; the amount he will purchase at one delivery, as well as competition. ${ }^{192}$

During 1938 and 1940 Red Indian's prices were evidently flexible and its price structure complex, for its President testified that "There has been such a wide fluctuation of prices that an independent recollection, to my mind, would be inconceivable, without referring to notes or to records."193

Furthermore, Red Indian at least occasionally offered its customers "advertising allowances." And, although Dworman testified that jobbers had to submit proof of advertising expenditures to receive the allowance, it is well known that "advertising allowances" often serve as a device for making discriminatory price concessions. And Dworman did not testify that the advertising allowance was the same to all buyers. ${ }^{194}$

One criticism of Standard's pricing practices rests upon another version of the role played by Red Indian and other small distributors in Detroit. Robert A. Wallace and Paul H. Douglas have asserted that:

Standard shared in the Detroit market with several of the other major oil companies. The record indicates that there was little or no price competition between the majors. There appears to have been no competition at all in the majors' tank wagon price (the price at which most of the gasoline was sold) although evidence was introduced to show that other majors had on occasion offered Standard's "Jobbers" gasoline at prices as low or lower than Standard's. Standard was the price leader. ... At times the independents' prices dropped as much as 6 cents below the price of major brands, and there were frequent "price wars" in the area.

The trouble, it appears, was caused by a small Michigan refinery named Red Indian. It seems that Red Indian was willing to take a lower price for its gasoline than Standard charged. Having itself neither storage nor distributing facilities in the Detroit area, there were few buyers to whom it could effectively offer its gaso-

${ }^{102}$ Record, 3099-3100.

${ }^{103}$ Record, 3100. Although the list of Red Indian's customers and the prices it charged each of them was not admitted into evidence, it is clear that, at any one time, different customers paid different prices. Record, 3103. Indeed, Red Indian's price structure was so complex, that Dworman was unable to testify to any regular differential between its tankwagon and tank-car prices: "Q: What was ordinarily the margin in 1938, '39, and '40 between your tank wagon price and your truck transport price? ... A: I don't believe I can answer that. ... A : . . . I believe that is a question that has too many answers. Trial Examiner Ballinger: You may explain your answer further, if you desire. The Witness: Well, transport prices have fluctuated without regard to tank wagon price. By Mr. Abbott: $Q$ : That is dependent on a lot of factors, isn't it? A: That is right." (Italics supplied.) Record, 3110.

${ }^{105}$ Record, 3107. It is interesting that Standard Oil of Indiana did not reimburse any customers for advertising. 
line. Standard therefore discriminated to meet Red Indian's offers to these particular buyers. Since these buyers had a choice between Standard's highly advertized gasoline and a less-known gasoline, both at the same effective price, they naturally chose the advertized brand. The result was that the smaller refiner was foreclosed from the Detroit market.

This situation poses the general problem: What chance is there for a small seller to break into the market against the discriminatory tactics of a large competitor? ... In summary, the effects of the discriminations in the Detroit area were to block the entry and growth of small refiners and, at the same time, to maintain high prices for major brand gasolines. ${ }^{195}$

The Wallace-Douglas position is erroneous in several respects. First, the record shows conclusively that the major oil companies were locked in competitive struggle with each other ${ }^{196}$ and with the so-called non-major companies. The record shows that gasoline prices at all levels fell substantially between 1936 and 1939, and that competition and changing demand conditions caused it. Second, the record gives grounds for doubting that Standard Oil was the price leader in Detroit in any meaningful sense of the word "leader." Third, "the trouble"-presumably the falling price level, declining profits and increased competition-was not caused by the Red Indian Oil Company, which was a very slight factor in the market, nor could it have been. Fourth, Red Indian was not a refiner, but a jobber of a well-known gasoline produced by an important oil company-the Standard Oil Company of Ohio. Fifth, Red Indian did have bulk storage facilities in Detroit, and it was served from a Detroit marine terminal. Sixth, it is difficult to understand in just what sense Red Indian was "foreclosed from the Detroit market." From about 1923 at least until 1941-I have no information after that-Red Indian was a gasoline jobber in and around Detroit! Seventh, there is good reason to believe that Red Indian, much as Standard itself, was discriminating in price in the sale of its gasoline. Eighth, even apart from the facts concerning Red Indian, it is difficult to see just how Standard's discriminations, as revealed by the record, should prevent socially desirable entry and competition. Assuming that Standard sold its gasoline at prices that at least covered the marginal cost of producing it-and selling for less would involve enormous losses that would be far greater than those incurred by smaller rivals who sold less-there is no cause for concern. That is to say, if at the prices Standard got for its gasoline it is better off with the sales to jobbers than without them, there is no antisocial consequence. For if the marginal cost of

\footnotetext{
${ }^{100}$ Wallace and Douglas, Antitrust Policies and the New Attack on the Federal Trade Commission, 19 U. of Chi. L. Rev. 684, 707-9 (1952). Consult also, Loescher, Geographical Pricing Policies and the Law, 27 J. of Bus. 211, 222-24 (1954) ; Gold and McGrath, Functional Discounts under the Robinson-Patman Act: The Standard Oil Litigation, 67 Harv. L. Rev. 294, 301 (1953).
}

${ }^{100}$ Some of them had newly entered the Detroit market, for example. 
Standard is lower than the average cost of prospective entrants there will be no entry, and there should not be. If the average cost of newcomers is lower than Standard's marginal cost, nothing Standard could do would stave off entrants. And it is difficult even to imagine how Standard would be willing to sell large amounts of gasoline at below marginal costs. It is even more difficult to imagine how it could survive for any length of time by doing so, even if it were willing.

The evidence clearly indicates that the three smaller gasoline suppliers analyzed here utilized a highly flexible and diverse pricing structure. It appears highly probable that they were discriminating in price among their customers. Furthermore, there is no evidence to indicate that the pricing practices or the differential pricing techniques used by their larger rivals even tended to drive them out of the market. They survived and, so far as the record shows, prospered. Contrary to many assertions, smaller firms can successfully intrude upon their larger rivals' province by cutting prices. Though they may face swift retaliation in doing so, that danger can be minimized. By nibbling away at their rivals' business through secret, discriminatory price cuts, smaller firms may (1) escape the detection of their rivals over longer periods, and (2) make their rivals unsure of the magnitude of price changes even when the fact of price changes is well known. Furthermore, small firms may have the important advantage of flexibility, simplicity of organization, and an appropriate irreverence for the existing price level. Larger firms may experience difficulty in detecting, evaluating, and acting on localized or specific market conditions. ${ }^{197}$ Small firms, on the other hand, may more readily accommodate their flexible and small organizations to slight or local market changes and imperfections. This would make possible for them a higher level of profits than would be possible if they could not discriminate. For they could thereby pick up new accounts without cutting prices to the old, and acquire more distributional outlets at a lower aggregate cost.

\section{Some Legal Aspects of the Standard Oil Case}

Analysis of the legislative history of the Robinson-Patman Act indicates that Congress wanted it to prevent price (or other kinds of) discrimination from undermining the competitive position of the various elements in the distribution process. That is, Congress sought to prevent discriminations from greatly changing the relative competitive position both of firms operating at the same "level" of the distributive hierarchy, and of firms operating at different levels of the hierarchy. Some interesting Robinson-Patman Act deci-

${ }^{107}$ The passage "through channels" of price recommendations within Standard Oil of Indiana seems to be an example of this sort of thing. Employees of the Company indicate that this sort of rigidity has been remedied. 
sions, including the Standard Oil of Indiana case, deal with price discounts that were given allegedly because the buyer performs certain valuable distributive functions, or because of the convenience and savings often characteristic of bulk sales to large distributors.

Under the Robinson-Patman Act charging different prices to competing buyers is suspect. ${ }^{198}$ If a seller can show that such price differences do no more than to reflect the differences in costs of serving his customers, he is saved; for cost justification is normally an absolute defense that is adequate irrespective of the competitive effects of the pricing practices complained of. However, in the past it has been extremely difficult successfully to justify a discount scheme through cost studies. ${ }^{109}$ Although the statute prohibits only

${ }^{198}$ The Standard Oil of Indiana case was brought under sections 2(a) and 2(b) of the statute, which read as follows: "2(a) That it shall be unlawful for any person engaged in commerce, in the course of such commerce, either directly or indirectly, to discriminate in price between different purchasers of commodities of like grade and quality, where either or any of the purchases involved in such discrimination are in commerce, where such commodities are sold for use, consumption, or resale within the United States or any Territory thereof or the District of Columbia or any insular possession or other place under the jurisdiction of the United States, and where the effect of such discrimination may be substantially to lessen competition or tend to create a monopoly in any line of commerce, or to injure, destroy, or prevent competition with any person who either grants or knowingly receives the benefit of such discrimination, or with customers of either of them: Provided, That nothing herein contained shall prevent differentials which make only due allowance for differences in the cost of manufacture, sale, or delivery resulting from the differing methods or quantities in which such commodities are to such purchasers sold or delivered: Provided, however, That the Federal Trade Commission may, after due investigation and hearing to all interested parties, fix and establish quantity limits, and revise the same as it finds necessary, as to particular commodities or classes of commodities, where it finds that available purchasers in greater quantities are so few as to render differentials on account thereof unjustly discriminatory or promotive of monopoly in any line of commerce; and the foregoing shall then not be construed to permit differentials based on differences in quantities greater than those so fixed and established: And provided further, That nothing herein contained shall prevent persons engaged in selling goods, wares, or merchandise in commerce from selecting their own customers in bona fide transactions and not in restraint of trade: And provided further, That nothing herein contained shall prevent price changes from time to time where in response to changing conditions affecting the market for or the marketability of the goods concerned, such as but not limited to actual or imminent deterioration of perishable goods, obsolescence of seasonal goods, distress sales under Court process, or sales in good faith in discontinuance of business in the goods concerned.

"(b) Upon proof being made, at any hearing on a complaint under this section, that there has been discrimination in price of services or facilities furnished, the burden of rebutting the prima-facie case thus made in showing justification shall be upon the person charged with a violation of this section, and unless justification shall be affirmatively shown, the Commission is authorized to issue an order terminating the discrimination: Provided, however, That nothing herein contained shall prevent a seller rebutting the prima facie case thus made by showing that his lower price or the furnishing of services or facilities to any purchaser or purchasers was made in good faith to meet an equally low price of a competitor, or the services or facilities furnished by a competitor." 49 Stat. 1526 (1936), as amended, 15 U.S.C.A. $\$ 13$ (a) (b) (1951).

${ }^{100}$ McGee, The Decline and Fall of Quantity Discounts: The Quantity Limit Rule in Rubber Tires and Tubes, 27 J. of Bus. 225 (1954). 
those discriminations that may "substantially . . . lessen competition . . . or ... injure, destroy, or prevent competition with any person who grants or ... receives the benefit of such discrimination" in practice the requisite "injury to competition" is easily demonstrated. ${ }^{200}$

In addition to the theoretic possibility of defending price differentials on the basis of costs, section 2(b) of the Robinson-Patman Act seems to offer an additional defense: "meeting competition." The determination of what that defense really means is one of the important issues involved in the Standard Oil of Indiana case, which has not yet been fully litigated.

The Federal Trade Commission's evaluation of Standard's price policy with respect to the four gasoline jobbers rested on four of its findings: (1) the volume of gasoline sold at retail in the Detroit area is rather constant, varying primarily with changes in the number of automobiles in use from year to year; (2) when sellers of the same grade of gasoline retail it at different prices, the public tends to patronize the cheapest source of supply, especially when different prices apply to the same brand; (3) the price advantage Standard gave the four jobbers, and which two-Citrin-Kolb and Ned'spassed along to consumers, tended to divert trade from the less favored retailers of Red Crown, and from retailers of other brands of gasoline; (4) the margin of gross profit on Red Crown gasoline sold in the Detroit area was low, averaging over the period analyzed by the Commission about 3.3 cents per gallon between tank-wagon and retail price. ${ }^{201}$

From these data, the Commission concluded that retailers who did not receive the low prices accorded the four jobbers were injured, as were dealers who retailed other competitive brands of gasoline. Standard's discriminatory policy, said the Commission, gave its favored customers a competitive advantage. ${ }^{202}$

The efforts of Standard Oil to justify its price discriminations on the basis of differences in the cost of selling to its customers did not persuade the Commission. Other service stations in the Detroit area had storage facilities sufficient to take single-load deliveries, and many single-load deliveries actually were made to them, although they paid the posted tank-wagon price.

Standard offered another defense: it made price concessions to the four favored dealers only after its competitors offered them equally low prices; it cut

${ }^{200}$ Ibid., pp. 225-27, and cases cited there.

${ }^{201}$ Furthermore, there was some evidence that gross profit rates below about 2 cents per gallon were insufficient for the retailers' survival over long periods.

${ }^{202}$ In the words of the Commission, "This competitive advantage is capable of being used, and by Ned's Auto Supply Company and to some extent by Citrin-Kolb Oil Company has been used, to divert large amounts of business from other retailers of gasoline, including customers of the respondent, with resultant injury to them and to their ability to continue in business and successfully compete with said dealers in the retailing of gasoline." (Italics supplied.) Standard Oil Co., 41 F.T.C. 263, 276 (1945). 
prices to hold their trade. The Trial Examiner concluded that the concessions Standard made "were granted to meet equally low prices offered by competitors on branded gasolines of comparable grade and quality."203 The Commission held that this evidence was irrelevant, since injury to competition had already been demonstrated. ${ }^{204}$

In support of its position that showings of low prices made by competitors will not justify price discriminations that may injure or lessen competition, the Commission proceeded to outline its conceptions of the burdens imposed upon it by law. The Commission indicated that a prima facie violation of the Robinson-Patman Act is established if the Commission shows jurisdiction, comparability of quality and grade of goods involved in the discrimination, and differences in (gross) prices charged competing resellers. From its prima facie case the Commission can draw, "[a] rebuttable presumption that the effect of such discrimination may be to substantially lessen competition or tend to create a monopoly or to injure, destroy or prevent competition. The burden then shifts to the respondent."205

After the Commission draws this "rebuttable presumption," the respondent must assume the burden of showing either that the discriminations were a good faith effort to meet equally low prices of a competitor; that its pricing policy did not injure or lessen competition or tend to produce a monopoly of any line of commerce; that the price differences made only due allowance for differences in the costs of manufacturing for, or selling or delivering to different purchasers; or that the different prices were made in response to changes which affected the market for or the marketability of the goods sold. Any of these showings by the respondent will rebut the Commission's prima facie case.

But if the Commission demonstrates that the respondent's mode of pricing tends to or has injured or lessened competition or tends to produce a monopoly, the respondent's only absolute defense is to show that its price differentials make no more than due allowance for cost differences, or that the different prices result from changes in the marketability of the goods sold. ${ }^{208}$

On the basis of its findings, the Commission ordered Standard to cease and desist from discriminating among competing resellers. In effect, the Commission's order compelled Standard to price in such a way as to preserve the competitive position of its reseller-customers. The order prohibited selling at lower prices to any one who resells at retail than those charged to competing retailers, except where price differentials were no greater than one-half cent

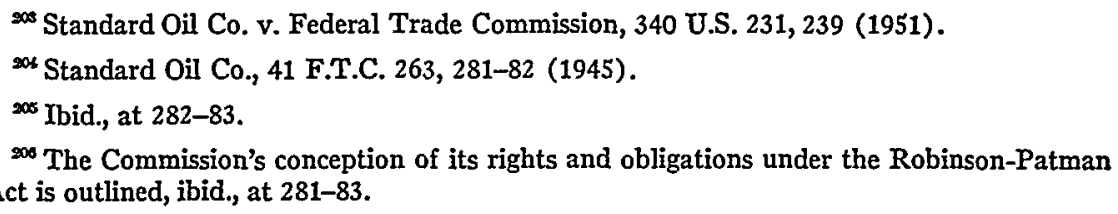


per gallon. ${ }^{207}$ It prohibited Standard from selling to any dealer, wholesaler, or jobber at lower prices than it charged competing retailers, where the dealers or wholesalers sell such gasoline to retailer customers for less than the posted tank-wagon price. Thus Standard Oil was to preserve price parity among large-quantity purchasers and the retailers who compete with them, as well as among retailer-customers of such large purchasers and other retailers who pay the tank-wagon price.

. On August 9, 1946, the Commission issued a modified cease and desist order against Standard of Indiana. ${ }^{208}$ Generally, the new order prohibited the same things as the earlier one. But it differed significantly in some respects. The new order did not permit Standard to discriminate by even as little as one-half cent per gallon. In addition, the modified order specifically exempted "discriminations" which made only due allowance for differences in cost, and those found to have no unlawful effect on competition. ${ }^{209}$

Standard Oil appealed to the United States Circuit Court of Appeals for the Seventh Circuit, which upheld the Commission's order. ${ }^{210}$ Circuit Judge Minton delivered the opinion, stating:

The petitioner had given a club to its wholesalers which they passed on to their retailers to bludgeon their competitors. This is what the Commission is trying to stop, and it is towards the elimination of this evil that the cease and desist order is directed. ${ }^{211}$

In reply to Standard Oil's strong objections to Paragraph $6^{212}$ of the

. 207 Ibid., at 284. It is not clear what the Commission's half-cent proviso meant. It could mean that the Commission concluded that discriminations of less than $\frac{1}{2}$ cent per gallon were not sufficiently great to lessen competition, and were therefore lawful. On the other hand, it could mean that discriminations of less than $\frac{1}{2}$ cent per gallon are lawful provided that they do not tend to injure or lessen competition. Finally, it might mean that the Commission concluded that differentials of less than $\frac{1}{2}$ cent per gallon were justified on the basis of cost differences, and were, therefore, lawful.

${ }^{208}$ Standard Oil Co., 43 F.T.C. 56 (1946). Commissioner Lowell B. Mason wrote a dissenting opinion saying that the order was too indefinite, that the Commission should have considered evidence applicable under the Section 2(b) proviso, that injury to competition had not been proved, and that jurisdiction had not been established. Ibid., at 59.

200 Economic theory indicates that "discriminations" that are precisely equal in amount to the differences in costs arising out of different sales are not discriminations at all.

${ }^{210}$ Standard Oil Co. v. Federal Trade Commission, 173 F. 2d 210 (1946).

211 Ibid., at 216.

${ }_{12}$ Paragraph 6 called for cessation of discrimination brought about "By selling such gasoline to any jobber or wholesaler at a price lower than the price which respondent charges its retailer-customers who in fact compete in the sale and distribution of such gasoline with the retailer-customers of such jobbers or wholesaler, where such jobber or wholesaler ... resells such gasoline ... to any of its said retailer-customers at less than respondent's posted tank-wagon price or directly or indirectly grants to any such retailer-customer any discounts, rebates, allowances, services or facilities having the net effect of a reduction in price to the retailer." Ibid., at 217 . In objecting to Paragraph 6, Standard contended that: "Paragraph 6 of the Modified Order directs Standard at its peril to prevent jobbers to whom it 
Commission's order, Judge Minton outlined courses of action which Standard could follow to comply with the order. Standard Oil, said Judge Minton, could follow one of two courses: it could stop selling to wholesalers at different prices than it gave to retailers; ${ }^{213}$ or it could, under its right to select its customers, refuse to sell to any wholesaler who sold to retailers at lower prices than those Standard charged to its own retailers. But the Court recognized that the burden of the Commission's order was very great: "To govern its conduct, the order makes the petitioner deal with its wholesalers at its peril as to what they might do with the gasoline in the future."214 This burden would have to be lightened, and the Court set about to lighten it. As the Court saw it, Standard does not and cannot control the prices at which its wholesalers sell their gasoline. Standard should not be forced to police its wholesalers, but should be liable if it sells to a wholesaler it knows or reasonably should have known is pricing or intends to price in ways prohibited by the Robinson-Patman Act. Thus Standard, to be liable, would have to sell to a wholesaler it should reasonably have known, or did know, was selling to others in violation of the Robinson-Patman Act. The Circuit Court so modified the Commission's order. ${ }^{215}$

It is important to recognize that, although it concluded that the Commission's order imposed too great a burden upon Standard, the Circuit Court agreed with the Commission that Standard's pricing was unlawful. The Circuit Court concluded that Standard's discrimination gave its favored customers an advantage over their competitors.

This competitive advantage is capable of being used and has been used by Ned's and to some extent by Citrin to divert large amounts of business from other gasoline retailers, including customers of the petitioner, with resultant injury to them and to their ability to continue in business and successfully compete with Ned's and Citrin in the retailing of gasoline. The effect of these discriminations in price allowed by the petitioner to Ned's, Citrin, Wayne, and Stikeman has been and may be substantially to lessen competition and to injure, destroy, and prevent competition with each of these four dealers and with their respective customers in the retail sale of gasoline. [Italics supplied.] ${ }^{216}$

Thus the Circuit Court agreed with the Commission that discriminations which divert trade among distributors are unlawful. Diversion of trade is therefore equivalent to a probable injury to or lessening of competition.

On appeal, the United States Supreme Court closely reviewed the question

sells gasoline and who are in competition with Standard in the resale thereof from reselling to their retail dealers at prices less than Standard's price . . . to maintain and regulate such competitor's prices on gasoline, title to which passed to the jobbers on delivery by Standard; and subjects Standard retroactively to punishment for contempt should a jobber-competitor fail to maintain such resale prices." Ibid., at 211.

${ }^{213}$ This was the policy of Standard Oil's three largest competitors in the Detroit area.

2s Tbid., at 217 . ${ }^{205}$ Ibid. ${ }^{218}$ Ibid., at 213. 
of defense under Section 2(b), the "good faith" proviso. ${ }^{217}$ To support its decision reversing the court below, the Supreme Court relied in part on the language and mechanical structure of the Act:

In its opinion in the instant case, the Commission recognizes that it is an absolute defense to a charge of price discrimination for a seller to prove, under $\S 2$ (a), that its price differential makes only due allowances for differences in cost or for price changes made in response to changing market conditions. . . Each of these three defenses [that the price differentials (1) make only due allowance for cost differences, (2) are in response to changing marketability of the goods, (3) result from a good faith effort to meet competition] is introduced by the same phrase "nothing ... shall prevent," and all are embraced in the same word "justification" in the first sentence of $\$ 2$ (b). It is natural, therefore, to conclude that each of these defenses is entitled to the same effect, without regard to whether there also appears an affirmative showing of actual or potential injury to competition at the same or a lower level traceable to the price differential made by the seller. The Commission says, however, that the proviso in $\S 2$ (b) as to a seller meeting in good faith a lower competitive price is not an absolute defense if an injury to competition may result from such price reduction. We find no basis for such a distinction between the defenses in $\S 2$ (a) and (b). ${ }^{218}$

Although it is clear, said the Court, that Section 2(b) does not permit discriminatory price concessions which cut below the "lower price" of a competitor, previous decisions amply demonstrate the admissibility and relevance of evidence that discriminatory prices were made to meet competitive offers. ${ }^{219}$

As an additional buttress for its conclusions, the Court relied upon the interpretation others had given the Act:

[T] here has been widespread understanding that, under the Robinson-Patman Act, it is a complete defense to a charge of price discrimination for the seller to show that its price differential has been made in good faith to meet a lawful and equally low price of a competitor. This understanding is reflected in actions and statements of members and counsel of the Federal Trade Commission. Representatives of the Department of Justice have testified to the effectiveness and value of the defense under the Robinson-Patman Act. We see no reason to depart now from that interpretation. ${ }^{220}$

${ }^{\text {ar }}$ Standard Oil Co. v. Federal Trade Commission, 340 U.S. 231 (1951). Mr. Justice Burton delivered the majority opinion.

21s Ibid., at 241.

${ }^{2}$ As the Court put it: "This right of a seller, under $\$ 2$ (b), to meet in good faith an equally low price of a competitor has been considered here before. Both in Corn Products Refining Co. v. Federal Trade Comm'n, 324 U.S. 726, and in Federal Trade Comm'n v Staley Mfg. Co., 324 U.S. 726, evidence in support of this defense was reviewed at length. There would have been no occasion thus to review it under the theory now contended for by the Commission. While this Court did not sustain the seller's defense in either case, it did unquestionably recognize the relevance of the evidence in support of that defense. The decision in each case was based upon the insufficiency of the seller's evidence to establish its defense, not upon the inadequacy of its defense as a matter of law." Ibid., at 243.

${ }^{20}$ Ibid., at 246-47. 
Concluding that "the legislative history, at best, is inconclusive,"221 the Court inferred:

Congress did not seek by the Robinson-Patman Act either to abolish competition or so radically to curtail it that a seller would have no substantial right of self-defense against a price raid by a competitor. 222

The Court concluded by explicitly contrasting the position of the Federal Trade Commission with its own:

In a case where a seller sustains the burden of proof placed upon it to establish its defense under $\$ 2$ (b), we find no reason to destroy that defense indirectly, merely because it also appears that the beneficiaries of the seller's price reductions may derive a competitive advantage from them or may, in a natural course of events, reduce their own resale prices to their customers. It must have been obvious to Congress that any price reduction to any dealer may always affect competition at that dealer's level as well as at the dealer's resale level, whether or not the reduction to the dealer is discriminatory. Likewise, it must have been obvious to Congress that any price reductions initiated by a seller's competitor would, if not met by the seller, affect competition at the beneficiary's level or among the beneficiary's customers just as much as if those reductions had been met by the seller. The proviso in $\S 2$ (b), as interpreted by the Commission, would not be available when there was or might be an injury to competition at a resale level. So interpreted, the proviso would have such little, if any, applicability as to be practically meaningless. We may, therefore, conclude that Congress meant to permit the natural consequences to follow the seller's action in meeting in good faith a lawful and equally low price of its competitor.

In its argument here, the Commission suggests that there may be some situations in which it might recognize the proviso in $\S 2$ (b) as a complete defense, even though the seller's differential in price did injure competition. In support of this, the Commission indicates that in each case it must weigh the potentially injurious effect of a seller's price reduction upon competition at all lower levels against its benefcial effect in permitting the seller to meet competition at its own level. In the absence of more explicit requirements and more specific standards of comparison than we have here, it is difficult to see how an injury to competition at a level below that of the seller can thus be balanced fairly against a justification for meeting the competition at the seller's level. We hesitate to accept $\S 2$ (b) as establishing such a dubious defense. On the other hand, the proviso is readily understandable as simply continuing in effect a defense which is equally absolute, but more limited in scope than that which existed under $\S 2$ of the original Clayton Act. ${ }^{223}$

In short, the Court ruled that proof that discriminations were made in response to equally low and lawful prices offered by competitors is sufficient to exempt those discriminations from the Robinson-Patman Act, even though the discriminations actually injure competition. The Supreme Court accordingly reversed, and instructed the Commission to determine whether Stand-

$$
21 \text { Ibid., at 248. Ibid., at 249. } \quad 200 \text { Ibid, at 250-51. }
$$


ard Oil has actually discriminated to meet equally low (and lawful) prices offered by its competitors. ${ }^{224}$

But the Court was by no means unanimous in its conception of the law. Justice Minton took no part in the consideration or argument of the case; Chief Justice Vinson, and Justices Black and Reed dissented. Justice Reed delivered the dissenting opinion. The dissenters compared the unamended Clayton Act with the law as amended, and concluded that the Robinson-Patman Act substantially restricted the ability of sellers to justify their discriminatory prices as good faith efforts to meet competition. As the dissenters saw it:

The need to allow sellers to meet competition in price from other sellers while protecting the competitors of the buyers against the buyers' advantages gained from the price discrimination was a major cause of the enactment of the 1936 RobinsonPatman Act. The Clayton Act of 1914 had failed to solve the problem. ${ }^{225}$

Although Congress intended to narrow the area in which price discrimination is permissible, the dissenters believed that the majority's decision thwarted that intent. ${ }^{226}$ As an argument against the Court's position that Congress never intended to deny a firm the right to discriminate to meet competition, Justice Reed countered:

Nondiscriminatory pricing tends to weaken competition in that a seller, while otherwise maintaining his prices, cannot meet his antagonist's price to get a single order or customer. But Congress obviously concluded that the greater advantage would accrue by fostering equal access to supplies by competing merchants or other purchasers in the course of business. ${ }^{227}$

To the dissenters, the legislative history of the Robinson-Patman Act meant something very different from what it meant to the majority of the Court. Their disagreement revolved about what Congress intended to achieve by the amendment:

The statutory development and the information before Congress concerning the need for strengthening the competitive price provision of the Clayton Act make clear that the evil dealt with by the proviso of $\S 2$ (b) was the easy avoidance of the prohibition against price discrimination. The control of that evil was an important objective of the Robinson-Patman Act. The debates, the Commission's report and recommendation, and statutory changes show this. The Conference Report and the explanation by one of the managers, Mr. Utterback, are quite definitive

$$
{ }^{224} \text { Ibid., at } 250 .
$$

sos "Congress intended so to amend the Clayton Act that the avenue of escape given price discriminators by its 'meeting competition' clause should be narrowed. The Court's interpretation leaves what the seller can do almost as wide open as before [the RobinsonPatman amendment] ... it seems clear to us that the interpretation put upon the clause of the Robinson-Patman Act by the Court means that no real change has been brought about by the amendment." Ibid., at 253 .

227 Ibid., at 253-54. 
upon the point. Because of experience under the Clayton Act, Congress refused to continue its competitive price proviso. Yet adoption of petitioner's position would permit a seller of nationally distributed goods to discriminate in favor of large chain retailers, for the seller could give to the large retailer a price lower than that charged to small retailers, and could then completely justify its discimination by showing that the large retailer had first obtained the same low price from a local low-cost producer of competitive goods. This is the very type of competition that Congress sought to remedy. To permit this would not seem consonant with the other provisions of the Robinson-Patman Act, strengthening regulatory powers of the Commission in "quantity" sales, special allowances and changing economic conditions. ${ }^{228}$

Though the majority relied partly upon the structural similarities between the proviso of Sections $2(a)$ and (b), Justice Reed noted the important differences:

The Robinson-Patman Act ... made two changes in respect of the "meeting competition" provision, one as to its location, the other in the phrasing. Unlike the original statute, $\S 2$ of the Robinson-Patman Act is divided into two subsections. The first, $\$ 2$ (a), retained the statement of substantive offense and the series of provisos treated by the Commission as affording full justifications for price discriminations; $\$ 2$ (b) was created to deal with procedural problems in Federal Trade Commission proceedings, specifically to treat the question of burden of proof. In the process of this division, the "meeting competition" provision was separated from the other provisos, set off from the substantive provisions of $\$ 2$ (a), and relegated to the position of a proviso to the procedural subsection, $\$$ (b). Unless it is believed that this change of position was fortuitous, it can be inferred that Congress meant to curtail the defense of meeting competition when it banished this proviso from the substantive division to the procedural. In the same way, the language changes made by $\S 2$ (b) of the Robinson-Patman Act reflect an intent to diminish the effectiveness of the sweeping defense offered by the Clayton Act's "meeting of competition" proviso. The original provisos in the Clayton Act, and the provisos now appearing in $\S 2$ (a), are worded to make it clear that nothing shall prevent certain price practices, such as price "differentials [making] ... due allowance for differences in the cost of manufacture ..." or "price changes . . . in response to changing conditions affecting the market for ... the goods concerned...." But in contrast to these provisions, the proviso to $\$ 2$ (b) does not provide that nothing "shall prevent" a certain price practice ... meeting a competitive price. The language thus shifts the focus of the proviso from a matter of substantive defense to a matter of proof. Consistent with each other, these modifications made by the Robinson-Patman Act are also consistent with the intent of Congress expressed in the legislative history. 229

263.

$220 \mathrm{Ibid}$, at 264-65. Brackets and parentheses in the original. Justice Reed also noted that the Court had placed improper emphasis on the meaning of the Staley and Corn Products cases. Said Justice Reed: in those cases "there was no occasion to consider the effect of a successful rebuttal." Ibid., at 265 . And "there was no occasion for this Court to meet the present issue." Ibid., at 266. 
Any evaluation of the Standard Oil of Indiana case should be made on two levels, legal and economic. From a legal standpoint, the Supreme Court's interpretation of Section 2(b) is somewhat discomfiting, for the weight of what evidence there is seems to lie on the side of the dissenters. The debates, reports, and other reflections of congressional intent indicate that Congress intended Section 2(b) only as a guide to procedure, and not as an absolute defense. According to this view, the law would run against discrimination that may injure or lessen competition regardless of whether the seller proves conclusively that he discriminated in good faith to meet competition. This is the interpretation of the Commission. It remains true, however, than any discussion of congressional intent is likely to be more polemical than fruitful, especially after the Supreme Court has already spoken.

On the economic level perhaps more fruitful conclusions can be drawn. That is a primary task set for the next section of this essay.

\section{Conclusion}

The pricing policies analyzed in this essay were effectuated during a depression period, and in considerable measure were the product of that setting. As might be expected, bad trade sharpened business rivalries. During the middle and late 1930's the Detroit gasoline market was highly competitive. New firms and new brands entered that market. Both "official" (posted) and real gasoline prices declined substantially during the period. Market shares varied. There is both direct and indirect evidence that price discrimination of a non-collusive, non-systematic, and opportunistic variety was prevalent at the refinery, wholesale, and retail levels of the market.

The non-collusive discrimination encountered in this case was the product of business rivalries. This discrimination was not only a symptom of competitive vigor, but an effective bar to cartelization as well. Sellers who discriminate among markets that are interdependent with respect to price, and do so at the expense of their rivals, are competing. Furthermore, however much retailers may try to cartelize-and the existence of contracts of substantial duration between retailers and refiners are an aid to "stabilization"the cost variations imposed by price discrimination will make their job doubly difficult. One of the first requirements of successful cartelization or "tacit cooperation" is standardization of grades of product, of buyer classifications (and of the "trade discounts" they may permissibly receive). Rivalry that exists through competitive redefinitions of "bona fide" dealers, jobbers, wholesalers, and commercial consumers, disrupts whatever price stabilization programs the industry may undertake. Members of the industry and commentators upon it have long recognized the destabilizing power of highly flexible "trade discount" classifications. In the words of one observer: 
Orderly marketing is impossible without such [standardized] classification. . . . One wonders sometimes if the oil industry recognizes that any such facts ["legitimate" reasons for giving discounts] underlie the true nature of discounts. At times it would almost appear that in this industry price differentials are granted for only one reason, a reason wholly unrelated to any question of savings, cost, or protection of channels: merely as an inducement to get somebody to sell gasoline. There is nothing in the economics of the oil industry that makes the application of classification and properly conceived discounts impossible. Moreover, until such results are achieved, marketing will continue to be chaotic. . . . To bring order out of chaos will involve some very hard thinking. It is likely to involve more or less coordinated action. It will undoubtedly cause the elimination of many dealers now distributing gasoline. There will be a widespread charge of monopolistic practice. But no other solution is possible. [Italics supplied.] $]^{230}$

There is no doubt that the declining price level injured some gasoline retailers as well as refiners. And, to the extent that price discrimination was the device through which price cutting was effectuated, price discrimination must carry some of the blame for these injuries. These were injuries sustained in a competitive struggle. Although it is sometimes said that competition tends to destroy itself through the accumulation of individual injuries and the eventual extinction of rivals, the case at hand lends no support to the notion. As Table 12 indicates, the number of retail filling stations increased considerably between 1933 and 1939 , a period that embraces the principal events studied in this essay, and from 1939 to 1948 - a period that includes extraordinary disruptions of World War II-declined substantially to the level of the early 1930's. Whatever the cause of its fluctuations, the number of stations was always high. And, in the absence of a showing that ownership concentration increased enormously, it is safe to guess that, so far as the limitations imposed by the number of sellers, gasoline retailing services will bring no more than the competitive return.

Similarly, the facts of the Detroit market show that entry into refining and jobbing was not only possible, but considerable. It is interesting that the large gains made by non-major brands in the Detroit market during the "thirties" were not transient. For example, consumer surveys made by the Standard Oil Company (Indiana) indicate that, in 1953-54 the Speedway Company sold an average of 11.4 per cent of all gasoline sold in the Detroit metropolitan area. It was then the fourth largest gasoline seller in that market. The same surveys show that the Sun Oil Company enjoyed about 23.7 per cent of the total business, and that Standard of Indiana was second with 20.7 per cent. Shell ranked third with 13.6 per cent. Speedway was fourth, and Socony Vacuum came fifth with 7.7 per cent. In general, there seems to have been a great deal of competition in the Detroit market.

In the light of what is known about the Detroit gasoline market during

${ }^{230}$ Lewis, The Marketing of Petroleum Products, 14 Harv. Bus. Rev. 312, 321-23 (1936). 
the period studied, the Supreme Court's rather liberal interpretation of the Robinson-Patman Act still restricts rivalry too much. And the situation may turn out to be even worse than that. The Commission's new findings that Standard's discriminations were not good faith meeting of competition as required by the statute indicate that the Supreme Court's new law may be subverted by re-findings of the appropriate "facts." 231 The Supreme Court sanctioned Standard's discrimination only under the assumption that Standard had discriminated to meet competition, as required for the defense offered by Section 2(b) of the Robinson-Patman Act. If Standard, or some other refiner, had initiated a price cut by discriminating in price among interdependent markets, it is entirely possible that the Court would have outlawed the discrimination. The Supreme Court's decision therefore does not appear to remove three possible inhibitions to price competition.

First, it may be that lawful lower prices must have been offered (or actually applied to sales) if price discriminations made to meet them are to be lawful. This would mean that no seller can initiate a discrimination that is likely to divert trade from his rivals or among his customers, unless he can defend those "discriminations" on the basis of cost-savings or changing marketability of his goods, ${ }^{232}$ and that no buyer can legally bargain discriminatory prices of this kind from any sellers, assuming that he knows that they are discriminatory. This would reduce the likelihood of aggressive price rivalry in oligopolistic markets.

Second, it may be that to qualify under Section 2(b), defensive price discrimination must have as its raison d'etre lower, but lawful, prices charged by competitors. If these lower prices must be lawful there would be a rub. Someone has to initiate the lower prices that constitute, for an individual seller, a defense under Section 2(b). If the initial lower price must either be non-discriminatory, exempt under the absolute defense provisos of Section 2(a), or must not have injurious effects upon competition, there would be a real problem. For injury to competition has come to mean injury to individual competitors. ${ }^{233}$ Barring a liberalization of the "injury to competition" requirement, in practice the initial price cutting would have to be non-discrimi-

${ }^{231}$ See Standard Oil Co., Docket No. 4389, Modified Findings, January 16, 1953. Since the preparation of this article the Seventh Circuit has reversed the Commission's new findings, holding that the record firmly established Standard Oil's good faith defense. Standard Oil Co. v. Federal Trade Comm'n, Seventh Circuit Slip Sheet No. 11409 (May 3, 1956). This would appear to establish more clearly the Supreme Court's interpretation and will certainly clear the status of the cases pending against some of Standard's major rivals in the Detroit area. It should also be noted that there are several bills pending before the Congress which would remove "good faith competition" as an absolute defense.

232 If these defenses are valid, he has not discriminated at all in the economic sense.

235 The Supreme Court decision does not alter that. It holds only that there may be competitive situations that justify this "lessening of competition." 
natory, or, if selective, justified under the defenses provided under Section 2 (a). Since in markets of relatively few sellers ${ }^{234}$ much if not most actual price competition develops as price discrimination in the economic sensewhich could not be justified under the cost proviso of Section 2(b)-it may very well be that, without unlawful initial discrimination there would be no "lower prices of competitors" for anyone to meet.

Third, it is possible that even when proof of competitors' lower (and lawful) prices can be made, a seller must meticulously avoid cutting below them if he is to stay within the law. This would inhibit competition in three ways: (1) it may be so expensive or difficult to determine what competitors' prices actually are that sellers may not meet prices they know are lower than their own, but of whose magnitude they cannot be sure. ${ }^{235}$ That might restrict the rapid spread of price cutting. (2) Some price cuts undoubtedly take place because sellers merely suspect someone is chiseling, or are told of fictitious "better offers" by their buyers, or believe that rivals' price cuts are imminent. Selective price cuts initiated for those reasons are unlawful. (3) The most aggressive price rivalry results when price beating rather than price matching is typical. Under the law price matching enjoys a much greater respectability than price beating, although price matching makes somewhat easier the achievement of non-competitive equilibrium and inflexible prices in markets of few sellers.

All of this is simply to say that allowing aggressive, as well as defensive, price discrimination tends to make oligopolistic markets function in a more competitive fashion. Neither the Commission nor the Court demonstrated that, under the circumstances of the Detroit gasoline market, unilateral, aggressive price discrimination would lessen competition in the broader sense, nor can I think of any way to make such a demonstration. On the other hand, there is evidence to show the competitive benefits of discrimination.

Government action might make the oil industry more competitive than price discrimination alone could ever make it. The abandonment of state controls over oil production and the dissolution of some major companies are possible but debatable policies. Evaluating them is not the function of this paper. One must begin somewhere, and this paper rests on the supposition that the structure of the industry is given. This has the merits both of realism and the isolation of causes.

In any case, even if it were possible to secure support for a thoroughgo-

${ }^{23}$ Or those that behave in the fashion believed by theorists to be characteristic of markets of few sellers.

${ }^{235}$ It might appear that such a fear is unlikely to prevent a seller from cutting prices more or less blindly once he is sure that competitors' prices are lower than his own, since the worst that could happen would be the issuance of a cease and desist order with no penalty other than costs of litigation. But this overlooks the possibility that buyers (or their customers) who are "injured" by the seller's discrimination will bring treble damage suits. 
ing modification of the oil industry's structure, it is not clear that society's interest would thereby best be served. This is in part the case because of the difficulty of developing criteria by which the need for modification may be judged. And even after the judicious application of all available and defensible social remedies, some industries will be more competitive than others because of conditions that surround the origins, growth, and normal operations of various lines of industry and trade. Society cannot compel the impossible, nor expect that all industries will be uniformly and continously competitive. What it can do is to remove those legal impediments to business practices that, while serving businessmen's self-interest, maintain or increase competition.

\section{APPENDIX}

TABLE 1

PERCENT OF WhOLESALE AND RETAII SALES:* STANDARD OII'S DETROIT JOBBERS, 1936-40

\begin{tabular}{|c|c|c|c|c|}
\hline 1036 & Ned's & Citrin-Kolb & Wayne & Stikemar \\
\hline $\begin{array}{l}\text { Number of Outlets Supplied................ } \\
\text { Percentage of Sales Made at Wholesale..... } \\
\text { Percentage of Sales Made at Retail....... }\end{array}$ & $\begin{array}{r}4 \\
0.0 \\
100.0\end{array}$ & $\begin{array}{l}43 \\
70.6 \\
29.4\end{array}$ & $\begin{array}{r}15 \\
100.0 \\
0.0\end{array}$ & $\begin{array}{l}21 \\
72.2 \\
27.8\end{array}$ \\
\hline 1937: & & & & \\
\hline $\begin{array}{l}\text { Number of Outlets Supplied.............. } \\
\text { Percentage of Sales Made at Wholesale..... } \\
\text { Percentage of Sales Made at Retail........ }\end{array}$ & $\begin{array}{r}4 \\
0.0 \\
100.0\end{array}$ & $\begin{array}{l}51 \\
84.6 \\
15.4\end{array}$ & $\begin{array}{r}19 \\
100.0 \\
0.0\end{array}$ & $\begin{array}{l}20 \\
90.9 \\
9.1\end{array}$ \\
\hline 1938: & & & & \\
\hline $\begin{array}{l}\text { Number of Outlets Supplied............... } \\
\text { Percentage of Sales Made at Wholesale..... } \\
\text { Percentage of Sales Made at Retail........ }\end{array}$ & $\begin{array}{c}6 \\
0.4 \\
99.6\end{array}$ & $\begin{array}{r}57 \\
92.7 \\
7.3\end{array}$ & $\begin{array}{r}21 \\
100.0 \\
0.0\end{array}$ & $\begin{array}{l}18 \\
99.7 \\
0.3\end{array}$ \\
\hline 1939: & & & & \\
\hline $\begin{array}{l}\text { Number of Outlets Supplied............... } \\
\text { Percentage of Sales Made at Wholesale..... } \\
\text { Percentage of Sales Made at Retail........ }\end{array}$ & $\begin{array}{r}6 \\
2.0 \\
98.0\end{array}$ & $\begin{array}{l}52 \\
89.9 \\
10.1\end{array}$ & $\begin{array}{l}24 \\
92.4 \\
7.6\end{array}$ & $\begin{array}{r}18 \\
100.0 \\
0.0\end{array}$ \\
\hline 1940: & & & & \\
\hline $\begin{array}{l}\text { Number of Outlets Supplied. } \ldots \ldots \ldots \ldots \ldots \\
\text { Percentage of Sales Made at Wholesale..... } \\
\text { Percentage of Sales Made at Retail. }\end{array}$ & $\begin{array}{l}6 \\
0.7 \\
99.3\end{array}$ & $\begin{array}{r}58 \\
93.5 \\
6.5\end{array}$ & $\begin{array}{l}24 \\
85.8 \\
14.2\end{array}$ & $\begin{array}{r}18 \\
100.0 \\
0.0\end{array}$ \\
\hline $\begin{array}{l}\text { Source: Resp. Exh. Nos. 53, 54, Record, 4873-74. } \\
{ }^{*} \text { As of December 31st of each year. }\end{array}$ & & & & \\
\hline
\end{tabular}


TABLE 2

\section{RETAII HOUSE-BRAND GaSOLINE PRICES AND MARGINS IN DETROIT, 1937-40 \\ (Prices in cents exclusive of taxes)}

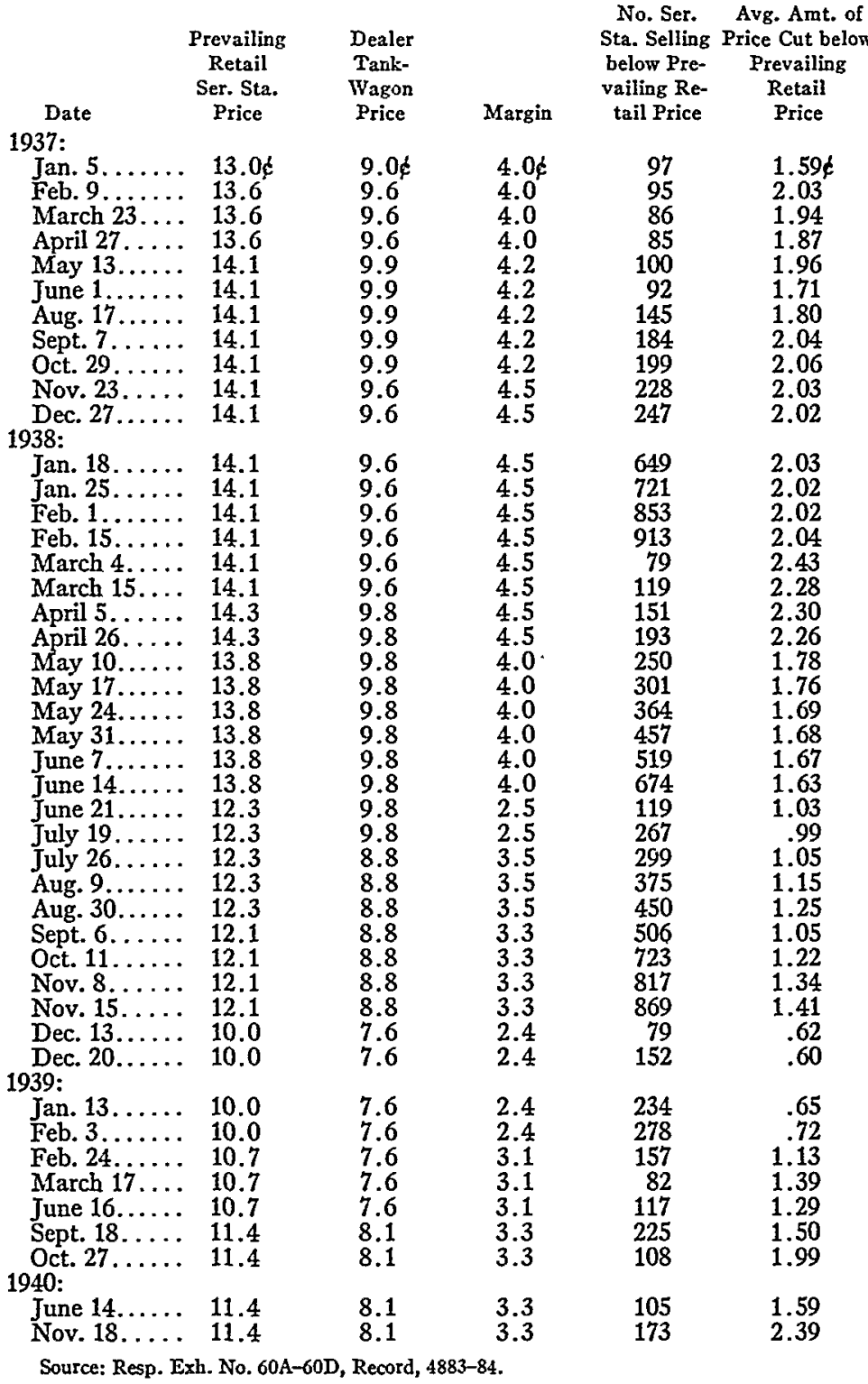




\section{TABLE 3}

Tank-Wagon and Tank-Car Prices of Red Crown Gasoline, Compared with

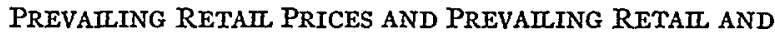
JOBBER MARGINS, JAN. 1, 1937-MARCH 6, 1941 (All prices are cents per gallon exclusive of taxes)

\begin{tabular}{|c|c|c|c|c|c|}
\hline Period & $\begin{array}{l}\text { Dealer } \\
\text { Tank-Wagon } \\
\text { Prices }\end{array}$ & $\begin{array}{l}\text { Jobber } \\
\text { Tank-Car } \\
\text { Prices }\end{array}$ & $\begin{array}{c}\text { Jobber } \\
\text { Margin }\end{array}$ & $\begin{array}{l}\text { tail Ser. Sta. } \\
\text { Prices for } \\
\text { "Regular" } \\
\text { Gasoline }\end{array}$ & $\begin{array}{l}\text { Retail } \\
\text { Dealer } \\
\text { Margin }\end{array}$ \\
\hline \multicolumn{6}{|l|}{ 1937: } \\
\hline $\begin{array}{l}\text { Jan. } 1 \text {-Feb. } 2 \ldots \ldots \ldots \\
\text { Feb. 2-May } 12 \ldots \ldots \\
\text { May } 12 \text {-Nov. } 3 \ldots \ldots \\
\text { Nov } 3 \text {. } 1937-\end{array}$ & $\begin{array}{l}9.0 \\
9.6 \\
9.9\end{array}$ & $\begin{array}{l}7.5 \\
8.1 \\
8.4\end{array}$ & $\begin{array}{l}1.5 \\
1.5 \\
1.5\end{array}$ & $\begin{array}{l}13.0 \\
13.6 \\
14.1\end{array}$ & $\begin{array}{l}4.0 \\
4.0 \\
4.2\end{array}$ \\
\hline $\begin{array}{l}\text { March 28, 1938.... } \\
\text { March 28-May 10.. } \\
\text { May 10-June 21.... } \\
\text { June 21-July 22..... } \\
\text { July 22-Sept. 6..... } \\
\text { Sept. 6-Dec. 9...... }\end{array}$ & $\begin{array}{l}9.6 \\
9.8 \\
9.8 \\
9.8 \\
8.8 \\
8.8\end{array}$ & $\begin{array}{l}8.1 \\
8.3 \\
8.3 \\
8.3 \\
7.3 \\
7.3\end{array}$ & $\begin{array}{l}1.5 \\
1.5 \\
1.5 \\
1.5 \\
1.5 \\
1.5\end{array}$ & $\begin{array}{l}14.1 \\
14.3 \\
13.8 \\
12.3 \\
12.3 \\
12.1\end{array}$ & $\begin{array}{l}4.5 \\
4.5 \\
4.0 \\
2.5 \\
3.5 \\
3.3\end{array}$ \\
\hline $\begin{array}{l}\text { Feb. 20, 1939..... } \\
\text { Feb. 20-April 10..... } \\
\text { April 10-June 17.... } \\
\text { June 17-Oct. } 11 \ldots \ldots \\
\text { Oct. 31-Nov. 11.... } \\
\text { Nov. 11-Nov. 18.... }\end{array}$ & $\begin{array}{l}7.6 \\
7.6 \\
7.6 \\
8.1 \\
7.4 \\
6.4\end{array}$ & $\begin{array}{l}6.35 \\
6.35 \\
6.1 \\
6.6 \\
6.15 \\
5.4\end{array}$ & $\begin{array}{l}1.25 \\
1.25 \\
1.5 \\
1.5 \\
1.25 \\
1.0\end{array}$ & $\begin{array}{r}10.0 \\
10.7 \\
10.7 \\
11.4 \\
9.3 \\
9.3\end{array}$ & $\begin{array}{l}2.4 \\
3.1 \\
3.1 \\
3.3 \\
1.9 \\
2.9\end{array}$ \\
\hline March 6, 1941.... & 8.1 & 6.6 & 1.5 & 11.4 & 3.3 \\
\hline
\end{tabular}




\section{TABLE 4}

\section{Ned's Posted RetaIl Prices CoMpared with Standard OIL'S TaNk-Wagon and}

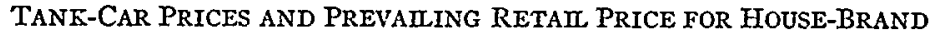
GASOLINE, DETROIT, FEB. 1, 1937-JULY, 1940*

(Cents per gallon exclusive of taxes) $\dagger$

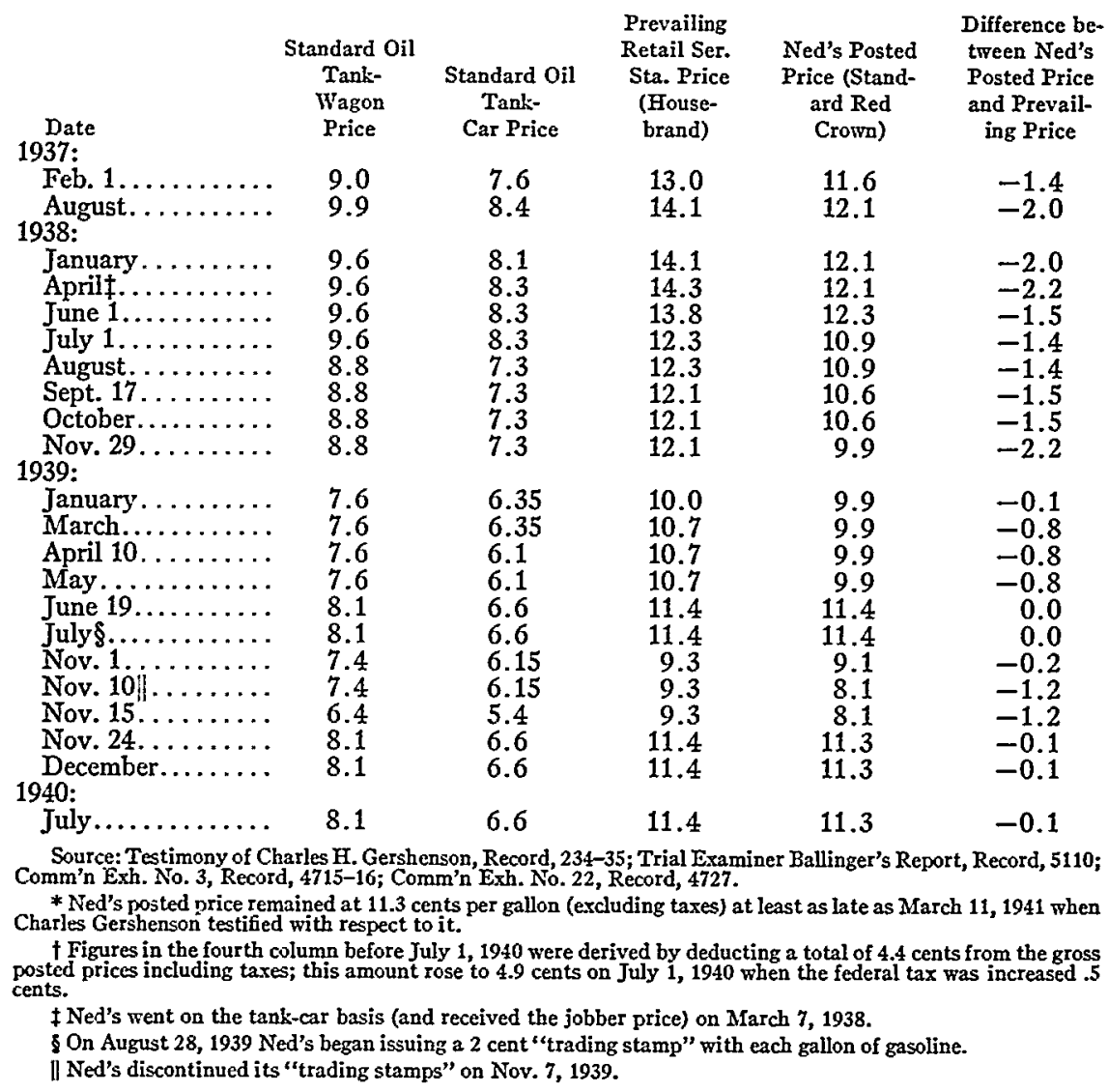

TABLE 5

GALIONAGE SOLD BY STANDARD OIL OF INDIANA* TO NED'S AUTO SUPPLY COMPANY

\begin{tabular}{|c|c|c|c|c|c|}
\hline RAND & 1936 & 1937 & $\begin{array}{c}Y_{E A R} \\
1938 \dagger\end{array}$ & 1939 & 1940 \\
\hline Jown. & & $\begin{array}{c}3,817,911 \\
268,535 \\
0\end{array}$ & $\begin{array}{c}4,517,621 \\
362,934 \\
0\end{array}$ & $\begin{array}{c}3,875,751 \\
460,564 \\
0\end{array}$ & $\begin{array}{c}3,874,657 \\
446,015 \\
0\end{array}$ \\
\hline & 49,000 & $4,086,446$ & $4,880,555$ & $4,336,315$ & $4,320,672$ \\
\hline
\end{tabular}

Standard Red Crown...

Solite with Ethyl.....

Stanolind.............

Total.

Source: 1937-40 figures are from Comm'n Exh. No. 100, Record, 4780-81.

* In any given year about ten per cent of Ned's total gasoline sales were made up of Ford Benzol gasoline. Record, 264 .

t During 1938, and thereafter, Ned's began to operate two additional filling stations, making a total of six. Thus though Ned's aggregate gallonage grew, its average per outlet declined. Record, 1860 .

$\$ 1936$ figure appears at Record, 263-64. 
TABLE 6

Difference between Red Crown Prices at Citrin-Kolb OIl Company STATIONS AND PREVAIIING HOUSE-BRAND GASOLINE PRICES:

DETROIT, JAN 1, 1937-FEB. 27, 1941

(Cents per gallon exclusive of taxes)

\begin{tabular}{|c|c|c|c|c|c|c|c|c|c|c|c|}
\hline \multirow[b]{2}{*}{ Period } & \multirow[b]{2}{*}{$\begin{array}{l}\text { Pre- } \\
\text { vailing } \\
\text { Price }\end{array}$} & \multicolumn{10}{|c|}{ Stations } \\
\hline & & $\begin{array}{c}\text { Liver- } \\
\text { nois } \\
\& \text { Lyn- } \\
\text { don }\end{array}$ & $\begin{array}{l}\text { Jefier- } \\
\text { son \& } \\
\text { Not- } \\
\text { ting- } \\
\text { ham }\end{array}$ & $\begin{array}{c}\text { Vernor } \\
\& \\
\text { Brush }\end{array}$ & $\begin{array}{c}\text { Wood- } \\
\text { ward \& } \\
\text { West- } \\
\text { minster }\end{array}$ & $\begin{array}{c}6 \text { Mile } \\
\& \text { Jos. } \\
\text { Cam- } \\
\text { pau }\end{array}$ & $\begin{array}{c}\text { Wyo- } \\
\text { ming } \\
\text { \& Ea- } \\
\text { ton }\end{array}$ & $\mid \begin{array}{c}\text { Lin- } \\
\text { Food } \\
\& \text { Pin- } \\
\text { gree }\end{array}$ & $\begin{array}{l}14445 \\
\text { Lin- } \\
\text { wood }\end{array}$ & $\begin{array}{l}8716 \\
\text { Lin- } \\
\text { Food }\end{array}$ & $\begin{array}{c}\text { Grand } \\
\text { River } \\
\& \\
\text { Iittle- } \\
\text { field }\end{array}$ \\
\hline 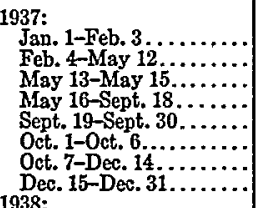 & $\begin{array}{l}13.0 \\
13.6 \\
14.1 \\
14.1 \\
14.1 \\
14.1 \\
14.1 \\
14.1\end{array}$ & $\begin{array}{r}0.0 \\
0.0 \\
-0.2 \\
0.0 \\
-2.0 \\
-2.0 \\
-2.0 \\
-2.0\end{array}$ & $\begin{array}{l}\cdots \\
\cdots \\
\cdots \\
\cdots \\
\cdots\end{array}$ & $\begin{array}{l}\ddot{ } \\
\because \\
\because\end{array}$ & $\begin{array}{l}\cdots \\
\cdots \\
\cdots \\
\cdots\end{array}$ & $\begin{array}{l}\cdots \\
\cdots \\
\cdots \\
\cdots \\
\cdots\end{array}$ & 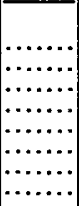 & $\begin{array}{r}0.0 \\
0.0 \\
-1.2 \\
0.0 \\
-2.0 \\
-2.0 \\
-2.0 \\
-2.0\end{array}$ & & $\begin{array}{r}0.0 \\
0.0 \\
-0.2 \\
0.0 \\
-2.0 \\
-2.0 \\
\cdots \cdots \\
\cdots \cdots\end{array}$ & 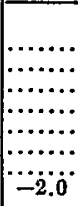 \\
\hline $\begin{array}{l}\text { 1938: } \\
\text { Jan. 1-Jan. } 21 \ldots \ldots \ldots \ldots \\
\text { Jan. 22-Jan. } 31 \ldots \ldots \ldots \ldots \\
\text { Feb. 1-Feb. } 15 \ldots \ldots \ldots \ldots \\
\text { Feb. 16-Feb. } 28 . \ldots \ldots \ldots \\
\text { March 1-March } 28 \ldots \ldots \\
\text { March 29-Aug. 12...... }\end{array}$ & $\begin{array}{l}14.1 \\
14.1 \\
14.1 \\
14.1 \\
14.1 \\
12.3 \\
\text { to } \\
14.3 \\
12.1\end{array}$ & $\begin{array}{c}-2.0 \\
-2.0 \\
-2.0^{*} \\
\ldots \ldots \ldots \\
\cdots \ldots \ldots\end{array}$ & $\begin{array}{r}-2.0 \\
-2.0 \\
-2.0 \\
-2.0 \\
-2.0 \\
0.0 \\
\text { to } \\
-2.0 \\
-1.2\end{array}$ & 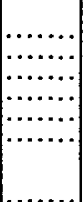 & 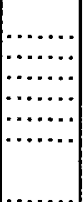 & 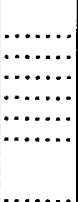 & 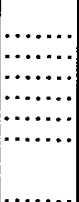 & $\begin{array}{l}-2.0 \\
-2.0 \\
-2.0 \\
-2.0 \\
-2.0 \\
0.0 \\
\text { to } \\
-2.0 \\
-1.2\end{array}$ & & $\begin{array}{l}\cdots \\
\cdots \\
\cdots \\
\cdots\end{array}$ & $\begin{array}{l}-2.0 \\
\cdots \cdots \cdots \\
\cdots \cdots \cdots \\
\cdots \cdots \cdots \\
\cdots \cdots\end{array}$ \\
\hline $\begin{array}{l}\text { Oct. 1-Oct. } 15 \ldots \ldots \ldots \\
\text { Oct. 16-Nov. } 1 \ldots \ldots \ldots \\
\text { Nov. } 2-\text { Dec. } 20 \ldots \ldots \ldots\end{array}$ & $\begin{array}{l}12.1 \\
\text { to } \\
12.3 \\
12.1 \\
12.1 \\
10.0 \\
\text { to } \\
12.1\end{array}$ & & $\begin{array}{r}-1.2 \\
\text { to } \\
-1.4 \\
-1.2 \\
-1.2 \\
0.0 \\
\text { to } \\
1.1\end{array}$ & & & $\because \because$ & $\begin{array}{l}\because \\
\because .\end{array}$ & $\begin{array}{c}-1.2 \\
\text { to } \\
-1.4 \\
-1.2 \mathrm{f} \\
\cdots \cdots \\
\cdots \cdots\end{array}$ & & & \\
\hline $\begin{array}{l}\text { Dec. 21-De } \\
\text { 1939: }\end{array}$ & 10.0 & & 0.0 & & & & & & & & \\
\hline $\begin{array}{l}\text { Jan. 1-Feb. } 19 . \ldots \ldots \ldots \\
\text { Feb. 20-March } 7 \ldots \ldots \ldots\end{array}$ & $\begin{array}{l}10.0 \\
10.7\end{array}$ & $\ldots \cdots \cdots$ & $\begin{array}{l}-0.05 \\
-0.05\end{array}$ & ........ & $\cdots$ & & & $\mid \cdots \cdots \cdots$ & & & \\
\hline $\begin{array}{l}\text { March 8-June 1 } 1 . \cdots \cdots \\
\text { June 2-June } 16 . \ldots\end{array}$ & $\begin{array}{l}10.7 \\
10.7\end{array}$ & $\begin{array}{l}-0.1 \\
-0.1\end{array}$ & $\begin{array}{l}-0.05 \\
-0.05\end{array}$ & {$[-0.1]$} & ....... & $\cdots$ & (n) & $\left(\begin{array}{c}\cdots \\
\cdots \cdots \cdots \\
\cdots \cdots \cdots\end{array}\right.$ & & & \\
\hline June 17-June 19. & 11.4 & -0.3 & -0.3 & -0.3 & 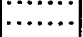 & $\cdots \cdots$ & $\cdots \cdots \cdots$ & (n...... & & & \\
\hline June 20.... & 11.4 & -0.1 & 0.0 & -0.8 & ....... & $\cdots \cdots$ & $\cdots \cdots \cdots$ & & & & $\cdots$ \\
\hline July 2 & 11.4 & -0.1 & 0.0 & -0.1 & $-0 . i$ & & .......... & {$[\ldots \ldots \ldots$} & & & $\ldots$ \\
\hline Aug. 17-Sept. $9 \ldots \ldots \ldots$ & $\begin{array}{l}11.4 \\
11.4\end{array}$ & $\begin{array}{l}-0.1 \\
-0.1\end{array}$ & $\begin{array}{l}0.0 \\
0.0\end{array}$ & $\begin{array}{l}-0.1 \\
-0.1\end{array}$ & $=0.1$ & $\begin{array}{l}-0.1 \\
-0.1\end{array}$ & $\cdots \cdots \cdots$ & $\cdots \cdots \cdots$ & & $\cdots$ & $\cdots \cdots$ \\
\hline Sept. 12 & 11.4 & -1.7 & -1.7 & -1.7 & -1.7 & $-0.1 f$ & $\cdots$ & ....... & & $\cdots$ & $\cdots$ \\
\hline $\begin{array}{l}\text { Sept. 13-Sept. 14.. } \\
\text { Sept. 15-Oct. } 7 \text {... }\end{array}$ & $\begin{array}{l}11.4 \\
11.4\end{array}$ & $\begin{array}{l}-1.7 \\
-1.7\end{array}$ & $\begin{array}{r}-1.7 \\
0.0\end{array}$ & $\begin{array}{l}-1.7 \\
-1.7\end{array}$ & $\begin{array}{l}-0.1 \\
-0.1\end{array}$ & $\begin{array}{l}-0.1 \\
-0.1\end{array}$ & (n...... & 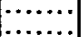 & & & $\ldots$ \\
\hline Oct. $8 \ldots . .$. & 114 & -0.1 & 0.0 & -0.1 & -0.1 & -0.1 & ........ & $\ldots \ldots$ & & & \\
\hline $\begin{array}{l}\text { Oct. } 9 \ldots \\
\text { Oct. } 10 \ldots\end{array}$ & $\begin{array}{l}11.4 \\
11.4\end{array}$ & $\begin{array}{l}-0.1 \\
-0.1\end{array}$ & $\begin{array}{l}0.0 \\
0.0\end{array}$ & $\begin{array}{l}-0.1 \\
-0.1\end{array}$ & $\begin{array}{l}-2.15 \\
-2.15\end{array}$ & $\begin{array}{l}-0.1 \\
-0.1\end{array}$ & 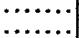 & $\cdots \cdots \cdot$ & $\cdots$ & anc. & $\cdots$ \\
\hline Oc & 11.4 & -0.1 & 0.0 & -0.1 & -0.1 & -0.1 & ......... & ....... & & $\cdots$ & \\
\hline $\begin{array}{l}\text { Oct. } 3 \\
\text { Nov. }\end{array}$ & 9. & $\begin{array}{l}+0.1 \\
-1.0\end{array}$ & $\begin{array}{l}+0 \\
-1 .\end{array}$ & $\begin{array}{l}+0.1 \\
-1.05\end{array}$ & -0.05 & $\begin{array}{l}+0.1 \\
-0.9\end{array}$ & 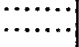 & 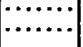 & & $\cdots$ & $\cdots \cdots \cdots$ \\
\hline $1940 \ldots$ & 11.4 & -0.1 & -0.1 & -0.1 & -0.1 & -0 & $\cdots$ & & & & \\
\hline June $20-\mathrm{Ju}$ & 11.4 & -0.1 & -0.1 & -0.1 & -0.1 & -0.1 & ….... & & & & \\
\hline & 11. & 0. & 0. & 0. & 0. & $\begin{array}{l}0 \\
0\end{array}$ & 00 & $\cdots$ & & & a...... \\
\hline & & 0. & 0. & & 0. & & & $\ddot{0} 0$ & & & \\
\hline & & 0.0 & & 0. & 0. & & 0.0 & 0.0 & 0.0 & $\ldots$ & \\
\hline $\begin{array}{l}\text { Dec. } 23 \\
\text { Dec. } 30\end{array}$ & & & & & 0 & & 0.0 & 0.0 & 0 & $\cdots$ & $\cdots$ \\
\hline 1941 . & 11.4 & & 0.0 & 0.0 & & 0.0 & 0.0 & 0.0 & 0.0 & & \\
\hline
\end{tabular}

Source: Adapted from Comm'n Exh. No. 32A-32C, Record, 4730-32; Comm'n Exh. No. 3A, Record, 4715; and from testimony of Max Biber, Record, $268 \mathrm{ff}$.

* Station not operated by Citron-Kolb after some unspecified date in February 1938.

† Station not operated by Citrin-Kolb after some unspecified date in October 1938.

$\mp$ This station gave free sugar with purchase of 8 gallons of gasoline from September 12, 1939 to October 9, 1939 . 
TABLE 7

Gasoline GaLloNage SOLd BY STANDaRd OIL OF INDIANa TO CITRIN-KOLB OII CO.

\begin{tabular}{|c|c|c|c|c|c|}
\hline & \multirow{3}{*}{1936} & & YeAR & & \\
\hline BRA & & 1937 & 1938 & 1939 & 1940 \\
\hline ed Crown... & & $\begin{array}{c}5,163,320 \\
337,845 \\
0\end{array}$ & $\begin{array}{r}5,404,717 \\
468,350 \\
86,803\end{array}$ & $\begin{array}{r}4,454,370 \\
504,883 \\
199,791\end{array}$ & $\begin{array}{r}4,618,115 \\
447,315 \\
160,700\end{array}$ \\
\hline & $014,359^{*}$ & $5,501,165$ & $5,959,870$ & $5,159,044$ & $5,226,130$ \\
\hline
\end{tabular}

Source: Figures for 1937-40 are from Comm'n Exh. No. 100, Record, 4780-81.

* 1936 figure from Record, 853-54.

\section{TABLE 8}

DIFFERENCE BETWEen PRICES at Wayne OII COMPANy STATIONS

AND THE PREVAIIING RETAIL PRICE FOR HOUSE-BRAND

GASOLINE, DETROIT, SEPT., 1939-DEC., 1940

(Cents per gallon exclusive of taxes)

\begin{tabular}{|c|c|c|c|c|c|c|c|c|}
\hline \multirow[b]{2}{*}{ DATE } & \multirow[b]{2}{*}{$\begin{array}{c}\text { Prevailing } \\
\text { Price }\end{array}$} & \multicolumn{7}{|c|}{ StattoNs } \\
\hline & & $\begin{array}{c}84000 \\
\text { W. } \\
\text { Chicago }\end{array}$ & $\begin{array}{l}13100 \\
\text { Liver- } \\
\text { nois }\end{array}$ & $\begin{array}{l}\text { Wyo- } \\
\text { ming \& } \\
\text { Brandt }\end{array}$ & $\begin{array}{c}2945 \\
\text { S. Fort }\end{array}$ & $\begin{array}{c}\text { Schaeffer } \\
\text { \& Tue- } \\
\text { man }\end{array}$ & $\begin{array}{c}10618 \\
\text { W. Jeffer- } \\
\text { son }\end{array}$ & $\begin{array}{c}\text { Grand } \\
\text { River \& } \\
\text { Mendota }\end{array}$ \\
\hline $\begin{array}{l}\text { 1939: } \\
\text { Sept. } 8 . . . . \\
\text { October.... } \\
\text { Nov. } 1 . . . \\
\text { Nov. } 15 . . . \\
\text { Nov. 17.... } \\
\text { Nov. } 18 . . . \\
\text { Nov. 19.... } \\
\text { Nov. 20.... } \\
\text { December.. } \\
\text { 1940: } \\
\text { January.... } \\
\text { February.. } \\
\text { March.... } \\
\text { April...... } \\
\text { May...... } \\
\text { June...... } \\
\text { July....... } \\
\text { August..... } \\
\text { September. } \\
\text { October.... } \\
\text { November. } \\
\text { December.. }\end{array}$ & $\begin{array}{r}11.4 \\
11.4 \\
9.3 \\
9.3 \\
9.3 \\
11.4 \\
11.4 \\
11.4 \\
11.4 \\
11.4 \\
11.4 \\
11.4 \\
11.4 \\
11.4 \\
11.4 \\
11.4 \\
11.4 \\
11.4 \\
11.4 \\
11.4 \\
11.4\end{array}$ & $\begin{array}{r}-1.2 \\
-0.1 \\
0.0 \\
0.0 \\
0.0 \\
0.0 \\
0.0 \\
-0.1 \\
-0.1 \\
0.0 \\
0.0 \\
0.0 \\
0.0 \\
0.0 \\
0.0\end{array}$ & $\begin{array}{r}-1.7 \\
-1.7 \\
-1.2 \\
\\
\\
0.0 \\
0.0 \\
0.0 \\
0.0 \\
0.0 \\
0.0\end{array}$ & $\begin{array}{r}+1.3 \\
-1.2 \\
-0.1 \\
-0.1 \\
-0.1 \\
-0.1 \\
-0.1 \\
-0.1 \\
-0.1 \\
-0.1 \\
-0.1 \\
-0.1 \\
0.0 \\
0.0 \\
0.0\end{array}$ & $\begin{array}{r}-1.2 \\
-0.1 \\
-0.1 \\
-0.1 \\
-0.1 \\
-0.1 \\
-0.1 \\
-0.1 \\
-0.1 \\
-0.1 \\
-0.1 \\
0.0\end{array}$ & $\begin{array}{l}-0.1 \\
-0.1 \\
-0.1 \\
-0.1\end{array}$ & $\begin{array}{r}-0.1 \\
0.0 \\
0.0 \\
0.0 \\
0.0 \\
0.0 \\
0.0\end{array}$ & $\begin{array}{l}-0.8 \\
-1.2\end{array}$ \\
\hline
\end{tabular}

Source: Data on posted prices including taxes are from Comm'n Exh. No. 54, Record, 4738; data on prevailing retail prices are from Comm'n Exh. No. 3A, Record, 4715 . 
TABLE 9

GALLONAGE SOLD BY STANDARD OF INDIANA TO WAYNE OIL COMPANY

\begin{tabular}{|c|c|c|c|c|c|}
\hline BRAND & 1936 & 1937 & $\begin{array}{l}\text { YEAR } \\
1938\end{array}$ & 1939 & 1940 \\
\hline $\begin{array}{l}\operatorname{Red} \text { Crown... } \\
\text { Ethyl. } \ldots \ldots \\
\ldots \ldots \ldots \ldots\end{array}$ & & $\begin{array}{c}1,570,149 \\
116,488 \\
0\end{array}$ & $\begin{array}{c}1,694,749 \\
130,289 \\
0\end{array}$ & $\begin{array}{c}2,029,429 \\
196,748 \\
0\end{array}$ & $\begin{array}{c}2,166,248 \\
175,146 \\
0\end{array}$ \\
\hline & $\begin{array}{l}1,438,348^{*} \\
1,348,348\end{array}$ & $1,686,637$ & $1,825,038$ & $2,226,177$ & $2,341,394$ \\
\hline
\end{tabular}

Source: Figures for 1937-40 are from Comm'n Exh. No. 100, Record, 4780-81.

* 1936 figure from Record, 991 (1,348,348). Note: at Record, 385 the 1936 figure is given as 1,438,000.

TABLE 10

Red Crown Prices Posted at Stations Operated BY THE STIKEMAN OIL COMPANY, DETROIT, JAN. 1, 1937-FEB. 14, 1938

(Prices are exclusive of taxes)

\begin{tabular}{|c|c|c|c|}
\hline Date & $\begin{array}{l}\text { Stikeman's } \\
\text { Price }\end{array}$ & $\begin{array}{c}\text { Prevailing } \\
\text { Price }\end{array}$ & Difference \\
\hline $\begin{array}{l}\text { Jan. 1, 1937-Feb. } 1,1937 \ldots \ldots \ldots \\
\text { Feb. } 2,1937 \text {-May } 11,1937 \ldots \ldots \\
\text { May } 12,1937 \text {-Feb. } 15,1938 \ldots \ldots\end{array}$ & $\begin{array}{l}13.0 \phi \\
13.6 \\
14.1\end{array}$ & $\begin{array}{l}13.0 \% \\
13.6 \\
14.1\end{array}$ & $\begin{array}{l}0.0 \% \\
0.0 \\
0.0\end{array}$ \\
\hline
\end{tabular}

Source: Comm'n Exh. No. 4, Record, 4716.

TABLE 11

GaSoline Gallonage SOLD BY STANDARD OIL OF INDIANA TO STIKEMAN OIL COMIPANY

\begin{tabular}{|c|c|c|c|c|c|}
\hline \multirow[b]{2}{*}{ BRAND } & \multicolumn{5}{|c|}{ YEAR } \\
\hline & 1936 & 1937 & 1938 & 1939 & 1940 \\
\hline Red Crown... & & $\begin{array}{c}2,273,665 \\
177,060 \\
0\end{array}$ & $\begin{array}{r}2,061,561 \\
185,423 \\
42,792\end{array}$ & $\begin{array}{r}1,802,973 \\
187,567 \\
32,430\end{array}$ & $\begin{array}{r}1,571,153 \\
176,508 \\
25,250\end{array}$ \\
\hline & data & $2,450,725$ & $2,289,776$ & $2,022,970$ & $1,772,911$ \\
\hline
\end{tabular}

Source: Figures for 1937-40 taken from Comm'n Exh. No. 100, Record, 4780-81.

TABLE 12

NUMBER OF FILLING STATIONS IN DETROIT, DEARBORN, HAMTRAMCK, AND HIGHLAND PARK, 1933, 1935, 1939, 1948

\begin{tabular}{|c|c|c|c|c|}
\hline City & $1933 *$ & $1935 \dagger$ & $1939 \ddagger$ & $1948 \S$ \\
\hline 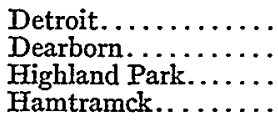 & $\begin{array}{r}1,496 \\
60 \\
50 \\
26\end{array}$ & $\begin{array}{r}1,728 \\
69 \\
55 \\
22\end{array}$ & $\begin{array}{r}1,873 \\
73 \\
65 \\
37\end{array}$ & $\begin{array}{r}1,578 \\
93 \\
50 \\
27\end{array}$ \\
\hline Total.. & 1,632 & 1,874 & 2,048 & 1,748 \\
\hline
\end{tabular}

* Sources: 1933 data are from U.S. Department of Commerce, Bur. of the Census, Census of American Business-Retail Distribution: 85 (1933).

+1935 data are from 2 Census of Business, Retail Distribution, County and City Summaries (1935)

$\ddagger 1939$ data are from 1 Census of Business, Retail Trade, Part 3 (1939).

$\$ 1948$ data are from 3 U.S. Census of Business, Retail Trade-Area Statistics (1948). 
TABLE 13

Physical Volume of Gasoline Sales in the Detroit AREa BY TYPE OF MARKETER:* 1936-40

1. Total sales made in Detroit area by all marketers (gallons) t..................

2. Total sales made in Detroit area by

3. Percentage of sales made by Standard Oil.

4. Sales made by Standard oil in Detroit, excluding sales made to jobbers (gallons)

5. Standard Oil's total non-jobber sales as percentage of total Detroit sales.......

6. Standard Oil sales to jobbers (gallons)..

7. Standard Oil jobber sales as percentage

of total Detroit sales...................

8. Sales of licensed jobbers and wholesalers
of major-brand gasoline excluding Standard Oil jobbers (gallons) $t \S . . . . . . . . .$.

9. Sales of major-brand jobbers $2 s$ percentge of total Detroit jales.

10. Sales of licensed jobbers and wholesalers of non-major brands of gasoline (gal-

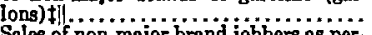

11. Sales of non-major brand jobbers as percentage of total Detroit sales

12. Total sales of all jobbers-total of $6, \overline{8}$, 10 (gallons) .........................

13. All jobber sales as percentage of total

14. Sales of all companies (including some majors) whose gallonage not elsewhere segregated $-1,4,12$ (gallons)

15. Unclassified sales as percentage of total Detroit sales.

1936

1937

YEAR

$363,735,380$

$62,198,750$

$409,445,610$

1938

1939

1940

17.1

$70,015,200$

$368,586,580$

$403,907,000$

$460,664,890$

17.1

17.1

$60,448,200$

$70,279,818$

$74,627,712$

$54,102,778$

$56,136,063$

16.4

17.4

16.2

14.9

13.7

$45,493,562$

$56,749,698$

$60,966,605$

$8,095,972$

$13,779,137$

12.3

2.2

3.4

$14,954,638$

$13,530.12$

13.2

4.1

3.3

$13,661,107$

$89,850,579$

$96,247,565$

$78,827,579$

$86,483,462$

$90,122,875$

24.7

23.5

21.4

21.4

19.6

$24,679,004$

$30,095,380$

$48,445,809$

$61,291,087$

$64,716,210$

6.8

7.4

13.1

15.2

13.9

$122,626,454$

$140,222,082$

$142,228,026$

$161,304,669$

$168,500,192$

33.7

34.3

38.6

39.9

36.5

$187,006,148$

$213,087,465$

$180,864,992$

$185,852,663$

$231,198,093$

51.4

52.0

49.1

46.0

50.3

Source: Adapted from Resp. Exh. No. 58, Record, 4879.

* Includes Highland Park, Hamtramck and Dearborn.

t Estimated from state tax records by assumption that gasoline consumption is proportional to automobile registrations. For details of the estimating procedure consult Record, 1937-39.

$\ddagger$ Michigan State Gasoline Tax Department Reports.

Consists of gallonage of firms listed in Resp. Exh. 55A-55B, Record, 4875-76.

[| Consists of gallonage of firms listed in Resp. Exh. 57A-57B, Record, 4877-78.

Mr. Raupagh testified that this column includes "all the major companies whose figures could not be segregated on the Gasoline Tax Reports as to gallonage in this area" (Record, 1934). 